\title{
Dynamics of Remittance Utilization in Bangladesh
}

\author{
Prepared for IOM by
}

Tom de Bruyn

Hoger instituut voor de arbeid, Katholieke Universiteit, Leuven

and

Umbareen Kuddus

IOM, Dhaka MRF, Regional Office for South Asia

January 2005

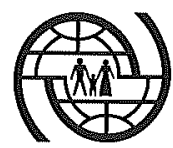

IOM International Organization for Migration 


\section{ACKNOWLEDGEMENTS}

We would like to thank Dr Johan Wets, Research Manager Sustainable Development, HIVA, for his comments and guidance and Mr Shahidul Haque, IOM Regional Representative for South Asia, for his support and contribution while conducting this study. We would also like to thank Nahreen Farjana, Zia Uddin Ahmed and the other staff members of IOM Dhaka MRF for their support during the field work in Dhaka.

We would like to thank all those who provided feedback on the report, in particular Frank Laczko, Chief, Research and Publication Division and Damien Thuriaux, Programme Officer, Labour Migration Service Area of IOM.

Special thanks also go to VLIR for the financial support for this research.

Finally, we would like to thank all the respondents and interviewees whose thoughts, ideas and information made this report possible. 


\section{TABLE OF CONTENTS}

\section{Introduction}

1. Methodology 7

1.1 Concepts 7

1.2 Methodology 7

2. Emigration Patterns and Dynamics in Bangladesh 10

2.1 Introductory note: The varied nature of migration in Bangladesh $\quad 10$

2.2 History of international migration in Bangladesh 11

$\begin{array}{ll}2.3 \text { The extent of migration } & 16\end{array}$

$\begin{array}{ll}2.4 \text { Who migrates? } & 18\end{array}$

2.5 Obstacles to the migration process 20

3. Volume and Dynamics of Remittances

3.1 Volume and origins of formal remittances $\quad 26$

3.2 Remittance channels and methods of transfer 29

3.3 Utilization of remittances 31

4. Impact of Remittances $\quad \mathbf{4 0}$

4.1. Impact of remittances on national economy 40

4.2 Impact of remittances at household and community levels 41

5. Initiatives and Policies Aimed at Harnessing

the Benefits of Remittances $\quad 46$

5.1 Encouraging labour migration to increase the level of remittances 46

5.2 Targeting remittance channel to formalize method of remittance 46

5.3 Tapping into non-resident remittances by facilitating investment 48

5.4 Influencing the utilization of remittances 49

6. Hindrances, Opportunities and Possible Avenues for

Enhancing the Impact of Remittances on the Broader Society

6.1 Hindrances and opportunities for enhancing the impact of remittances on the broader society

6.2 Possible avenues to enhance the impact of remittances on the broader society 
Annex A: Micro-level studies on migrants (and remittances)

in Bangladesh

Annex B: Persons interviewed

Annex C: Official migration from Bangladesh by country of employment and remittance flow (1976-2004)

Annex D: Country-wise remittance flow into Bangladesh (1997-2004)

Annex E: List of Bangladeshi and international studies and papers that explore possible avenues to enhance the development impact of remittances

Annex F: Abbreviations 


\section{INTRODUCTION}

\section{"Remittances have been causing a silent economic revolution in Bangladesh"!}

In recent years politicians and academics have discovered the importance of remittances to economic development of the origin countries of migrant communities. According to official estimates, some US\$ 93 billion were remitted to developing countries in 2003. This makes official remittances the second-largest financial flow to developing countries after foreign direct investment (World Bank, 2004), surpassing the official aid flow to this region (IOM, 2004). Bangladesh receives an important share of this global flow, i.e. 2 per cent, and accounts for 12 per cent of the official remittances flowing into South Asia (Kuddus, 2003).

Every year some 200,000 or more Bangladeshis leave the country officially to work elsewhere. In the last 29 years 3.8 million temporary labour migrants have been recorded. Add to this the more than 1 million Bangladeshis living permanently outside the country and the extent of emigration becomes apparent. Most of these migrants send part of their earnings home on a regular or irregular basis. Together this amounted to more than US\$2 billion annually between 2000 and 2002 and even 3 billion in 2003 (Siddiqui, 2003; BMET; Bangladesh Bank and IMF figures).

It is not easy to determine the exact impact of this flow at the household and community levels. One school of thought maintains that remittances are merely used to satisfy the consumption needs of the family at home and are not used for productive investment, and therefore fail to have the multiplier effect to benefit the broader community. However, as the above mentioned quote indicates, it is widely held that remittances have a major impact on the Bangladesh economy and society as a whole.

This report, funded by the Flemish Interuniversity Council (VLIR) and carried out by the Higher Institute for Labour Studies (HIVA) in collaboration with the International Organization for Migration (IOM), Dhaka, attempts to answer the following three research questions:

- What is the impact of remittances on households and the broader community in Bangladesh?

- What are the initiatives taken by the government or other actors to enhance the impact of remittances?

- What are the major hindrances, opportunities and possible avenues for the enhancement of the impact of remittances on society as a whole? 
To answer these questions, an analysis of migration patterns, as well as of the remittance dynamics is needed. These issues will be addressed in Chapters Two and Three, while Chapters Four, Five and Six will attempt to answer the three research questions.

The report draws extensively on secondary sources, interviews as well as the existing literature, and thus brings together the existing knowledge on the issue in Bangladesh. 


\section{METHODOLOGY}

\subsection{Concepts}

There are several definitions of remittances. In the broadest sense, remittances refer to cash or in-kind transfers from one place to another. As Van Doorn (s.d.) notes, different types of remittances can be distinguished: international or intranational, individual or collective, formal or informal, in kind or in cash or only financial. In the literature, authors often use a narrower definition of remittances. In this report, remittances refer to financial international transfers. In practice this means money sent back to Bangladesh by nationals or emigrants, including the diaspora, from the country where they are living or working.

In the report a theoretical distinction is made between migrant workers and diaspora. According to the UN International Convention on the Protection of Migrant Workers' Rights, the term migrant workers refers to persons who are engaged in remunerative activities in a state of which he or she is not a national (UN General Assembly, 1990). Siddiqui (2004b: 7) defines diasporas as "transnational groups of immigrants living abroad but maintaining economic, political, social and emotional ties with their homeland and with other diasporic communities of the same origin". Both concepts overlap to a certain extent and a person can shift from being a migrant worker to belonging to the diaspora or vice versa. In general, the migrant worker's relationship with the destination country is of a (perceived) temporary nature, while that of the diaspora is of a more permanent or long-term nature.

\subsection{Methodology}

The information for this report was gathered through a literature study and interviews with relevant actors. The literature study was mostly done in Belgium, while the interviews were carried out during a three-week visit to Bangladesh (from 1 to 20 December 2003).

\subsubsection{Literature Review}

The review of the literature focused mainly on studies and papers written about migration and/or remittances in Bangladesh. Unfortunately, data and information on international migration and remittances in Bangladesh are relatively limited. Among the most important centres that have carried out research on the topic are the Refugee 
and Migratory Movement Research Unit (RMMRU) of the University of Dhaka (e.g. Prof. Dr Tasneem Siddiqui), and the Bangladesh Institute of Development Studies (e.g. Prof. Dr Rita Afsar and Prof. Dr Raisul A. Mahmood). Furthermore, the International Organization for Migration (IOM) and the International Labour Organization (ILO) have also commissioned a number of studies.

Micro-level studies and case studies in specific regions and/or about particular subjects, carried out by scholars, form an additional source of information. Although these studies are often very detailed, they can only offer a partial view of the dynamics and the scope of international migration and remittances in Bangladesh. The case studies have been listed in Appendix A.

The existing studies do not cover all aspects of migration and remittances. Issues which have received particular attention include the process of labour migration; the methods of remitting; the utilization of remittances at the household level (see also Murshid et al., 2003); and the socio-economic conditions of returnee migrants. Female migration, the impact of remittances at the community level and the Bangladeshi diaspora belong to the less researched topics.

In general, reliable data on emigration from Bangladesh is hard to find. According to INSTRAW and IOM (2000), three institutions provide official data on migration statistics. The Bureau of Manpower Employment and Training (BMET), a department within the Ministry of Expatriate Welfare and Overseas Employment (MEWOE) responsible for keeping track of Bangladeshis employed overseas, began to keep systematic records of migrant workers from 1976. Data is available on the total number of persons who have emigrated for employment, the skill composition and the countries of destination. However, these figures only reflect the number of people leaving the country through official channels and are assumed to be underestimated. The Bangladesh Bank (BB), the central bank of the country, publishes annual figures of remittances sent by Bangladeshi workers. Records of every Bangladeshi national leaving the country through official channels can be found at the Immigration Department of the Ministry of Home Affairs. However, neither of these institutions keeps records of more specific information on migration (for instance, gender breakdown). A fourth institution, mentioned by Afsar (2003), is the Bangladesh Bureau of Statistics. However, the census data of Bangladesh only provide information about the place of birth (Hossain, 2001 and Skeldon, 2003).

\subsubsection{Interviews}

The literature study was supplemented by a series of interviews with relevant actors in the area of migration and remittances. These included government agen- 
cies, banks, micro-finance institutions (MFIs), non-governmental organizations (NGOs), international organizations, migrant associations, trade unions, media and research institutions. In total, about 30 different actors were interviewed. Furthermore, a number of institutions were contacted by phone or mail, but replied that they either were not familiar with the research subject, or were not available during the time of the research. Lastly, four British and American academics, who have carried out research on remittances and migration in Bangladesh, were contacted by mail for additional advice and information.

Most of the interviews were conducted in Dhaka, Bangladesh. The field study in Bangladesh also included visits to two different projects that focused on returnee migrants and migrant families - one in Sirajgang and one in Daudhkandi - and a two-day field trip to Sylhet, an area with strong links to the Bangladeshi diaspora in London.

Detailed information on the persons and actors interviewed is available in Appendix B.

\subsubsection{Collaboration}

The study was carried out in the framework of the policy-oriented research of the Vlaamse Interuniversitaire Raad (VLIR) and funded by the Belgian Directorategeneral for Development Cooperation. The preliminary work in Bangladesh was carried out by the Higher Institute for Labour Studies (HIVA), Katholieke Universiteit Leuven, Belgium. In Bangladesh, HIVA collaborated with IOM, Dhaka MRF (Mission with Regional Functions), Regional Office for South Asia. Besides logistic and organizational support, IOM also offered intrinsic advice. The final report is written by Tom De Bruyn (HIVA) and Umbareen Kuddus (IOM). 


\section{EMIGRATION PATTERNS AND DYNAMICS IN BANGLADESH}

\subsection{Introductory note: The varied nature of migration in Bangladesh}

As Siddiqui (2003) states, Bangladesh has a long history of migration. Migration has shaped and is still shaping Bangladeshi society. Although this report does not focus on internal migration, it must be acknowledged that most migratory movements happen within the country. Some micro-level studies give an idea of the importance of migration in rural villages. A study in 62 villages in Bangladesh by Rahman, Hossain and Sen in the early 1990s (cited in Afsar, 2003), showed that three-quarters of those migrating from rural areas migrate internally, and some 24 per cent migrate overseas, while Hossain's study (Hossain, 2001) in rural villages in the district of Comilla showed that internal migration accounted for 63 per cent the total migratory movements within that area.

As in many other low-income countries, most migrants move from rural to urban areas. For instance, a highly developed migration process connects the rural southern districts of Bangladesh to Bangladeshi main cities (Kuhn, 2002). On a smaller scale, though still important in absolute terms, is rural to rural migration and even urban to rural migration. Skeldon (2003) notes that internal migration has increased significantly since independence in 1971.

Internal and international migration are often related. For instance, many international migrants have first moved within the country before they decided to go abroad. Furthermore, migration from one area also causes a need or void that fuels further migratory movements. As Dr Chowdhury of Shajalal University argues, ${ }^{2}$ the district of Sylhet has been attracting migrants from neighbouring districts, due to the high rates of international migration from the area.

The first traces of external migration from Bangladesh can be found in Sri Lankan mythology. The Singhala communities, the original inhabitants of Sri Lanka, are believed to have migrated from Bangladesh (Siddiqui, 2004b). More recently, before the partition of the Indian subcontinent, there was large-scale emigration of Bangladeshis to Assam, and to Myanmar. This followed the destruction of the jute and cotton industries and the market for fine muslin by the colonial powers to protect their own industries. After the independence of India and Pakistan in 1947, migration to neighbouring states was restricted due to regulatory mechanisms. Still, 
migration to neighbouring countries continues - even though it is sometimes illegal and forced in nature. Shah et al. (2002) estimate for instance that over 30,000 girls have been trafficked from Bangladesh to India in the last ten years and are exposed to various forms of exploitation.

However, cross-border movements and trafficking will not be dealt with in this report. This does not necessarily mean that these migration flows are not important for discussion on remittances. Unfortunately, they do not feature in the debate about remittances in Bangladesh. Therefore information on this subject is very hard to find.

The movements highlighted above do not belong to the scope of this research. Which migration flows do matter for this study?

International remittances come mainly from three large, but distinct types of migrant. Firstly, there is an important, mainly American and British, diaspora of well-educated, high or middle income earners. Secondly, there is a diaspora of Bangladeshi origin, in the same countries and other industrialized countries, belonging to the low-income or unemployed segments of the population. Thirdly, there is a major group of migrant labourers, residing for a specific period in Middle Eastern, SouthEast Asian and some industrialized countries. These migration movements are not unique for Bangladesh, but show similarities with other South and East Asian countries (see, for instance, Skeldon, 2003; Waddington, 2003; Wickramasekera, 2002).

The following paragraphs contain more information on each of these migrations flows.

\subsection{History of international migration in Bangladesh}

\subsubsection{The diaspora to the industrialized countries}

The origins of migration to industrialized countries can be traced back to the colonial past. From the eighteenth century onwards, sailors originating from the southeastern part of Bangladesh (mainly Chittagong and Noakhali) found employment in the British merchant navy, and travelled from the port of Kolkata to different parts of the world. The most important group of emigrants, however, were landless peasants of northern Sylhet district. ${ }^{3}$ Lack of employment opportunities stimulated them to seek opportunities elsewhere. Working on ships or even as stowaways, they migrated to a number of countries, of which the UK and the USA are the most important (Siddiqui, 2003). 
A second wave of migration to the UK occurred in the 1950s and to the US in the 1960s. The UK, as many other northern European countries, experienced a labour shortage, especially in low-skilled industries. It attracted labour migrants from its former colonies to work in heavy industries. Bangladeshis went mainly to northern cities, such as Birmingham and Oldham. After the crisis in heavy industry in the 1970s, many of them moved to London, specifically to the borough of Tower Hamlets. In later years they brought their wives and children. Thus, the temporary migration became permanent. Nowadays, most Bangladeshis living in the UK belong to the lower-income groups and experience high unemployment rates. A small number of Bangladeshis came to the UK to pursue higher studies.

The second migration wave to the USA was of a very different nature. Most migrants were students and professionals who chose to remain in their new country, rather than return to Bangladesh. Like those who migrated for higher education to the UK, many of the Bangladeshis who moved to the USA also adopted the nationality of the destination country. Currently Bangladeshi communities can be found in major cities such as New York, Boston, New Jersey and Dallas. Bangladeshis are still coming into the country under specific visa schemes. Contrary to the British diaspora, the origin of the American diaspora is more dispersed and cannot be traced back to one single region. Besides the UK and the USA, significant numbers of Bangladeshis migrated to Italy, Canada, Japan, Australia and Greece (Siddiqui, 2004b).

\subsubsection{Labour migrants to the Middle East and South-East Asia}

In contrast to the migration to industrialized countries of the West, migration to the Middle East and South-East Asia has been characterized by short-term employment, with specific job contracts and migrants returning home after completion of the contract period.

International migration to the Middle East started after the independence of Bangladesh in 1971. The infrastructure development boom following the rising oil prices in 1973 fuelled the demand for labour migrants in Middle Eastern countries and especially the Gulf States (i.e. Saudi Arabia, Kuwait, Bahrein, Qatar, Oman and the UAE). Cheap labour was found in South and South-East Asia. Later also the newly industrialized countries of South-East Asia (Singapore, Malaysia, South Korea) went through a similar expansion boom and needed migrant workers to fill the demand for unskilled workers (Siddiqui, 2003).

In 1985 the oil prices fell and migration from Asia decreased, although rising employment in service and maintenance sectors kept the demand for labour migrants high. In general, the employment of labour migrants abroad is quite sensitive to the 
prevailing socio-political environment of the receiving countries. The Gulf crisis in the 1990 s forced the return of some 56,000 workers back to Bangladesh from Kuwait and Iraq, and the Asian financial crisis of 1997-98 resulted in a decrease in the demand for labour migrants (Murshid et al., 2002). In addition, the last few years saw increased competition from new labour-sending countries like Nepal, Cambodia and Viet Nam.

Labour migration does not only limit itself to the Middle East and South-East Asia. The migration flow to the USA, the UK and other industrialized countries also includes a significant proportion of labour migrants. For instance, Sylheties are still moving to London in order to work in family businesses, like restaurants; and negotiations between the Italian and the Bangladesh governments will most probably result in the sending of 300 labour migrants to the Southern European peninsula. ${ }^{4}$ Furthermore some African oil exporting countries, such as Libya and Nigeria, also attract labour migrants (Afsar et al., 2002).

Official estimates and the prevailing literature suggest that external labour migration is concentrated mainly in the districts of Sylhet, Chittagong, Noakhali, Comilla and Dhaka (Murshid et al., 2002). In certain instances, destination regions attract labour migrants from particular regions. The link between Sylhet and Tower Hamlets is without any doubt the best example. According to Dr Ahmad of the research centre Bangladesh Union Parishad (BUP), ${ }^{5}$ migration to Rome, Italy can be traced back to Faridpur district. Female migrant workers come mainly from the greater Dhaka districts and nearby districts of Mushinganj, Manikganj and Chadnpur (INSTRAW and IOM, 2000).

\subsubsection{Why do Bangladeshis migrate?}

The motivations for migrating differ to a certain extent between the diaspora and the short-term labour migrants. According to Siddiqui (2003), migrants to Western industrialized countries have listed better educational opportunities for their children, access to specialized jobs, better health care systems, and wider opportunities for self-actualization as pull factors, and political turmoil, violence, insecurity and corruption as push factors. Another important reason for long-term migration is family reunion. Short-term labour migrants to the Middle East and South-East Asia on the other hand migrate mainly in search of better job opportunities and to escape unemployment and poverty. Furthermore, the decision to migrate is influenced by the available information on migration and job opportunities, the existence of social networks and the operation of recruiting agencies (Abdul-Aziz, 2001; Hossain, 2001; Mahmood, 1991; Siddiqui, 2003). 
Gender-specific factors include women's need to escape unhappy social situations (such as domestic violence, lack of independence and opportunities for selfactualization). This accounts for semi-skilled and unskilled female migration to the Middle East as well as for the migration of professionals or students to countries like the UK, the USA and Australia (INSTRAW and IOM, 2000; Siddiqui, 2003).

\subsubsection{How do Bangladeshis migrate?}

Once a migrant decides to go abroad s/he has to organize a number of issues, such as the travel, the visa, securing employment, etc.

Over time, as Afsar et al. (2002) note, three major channels have emerged to assist the migrant in this process: via help from friends, family or middlemen; through recruitment agencies; and through the governmental agency, the Bangladesh Overseas Employment Services Limited (BOESL). ${ }^{6}$

In most cases (53\% according to the authors) family members, friends or dalals offer assistance. Often the friends and family members are already residing in the destination country, or have undertaken a similar migration earlier. Migrants who belong to an already well-established migrant community migrate in this way. The best example is the Sylhet - Tower Hamlets link. Individual migrants can even turn to the UK-based charity Immigration Advisory Service (IAS). IAS gives legal advice and assistance for pre-application enquiries to immigrants and asylum seekers for a registration fee of 600 taka. $^{?}$

Dalals on the other hand, are middlemen who assist the migrant for payment. They are not recognized by the government. It is mostly unskilled and semi-skilled migrants who use this channel.

In 45 per cent of the cases, private recruitment agencies offer assistance in return for payment. In total there are more than 700 officially licensed private recruitment agencies in Bangladesh. They work under licence to the government. Since 1984, they have been grouped under the national umbrella organization known as Bangladesh Association of International Recruitment Agencies (BAIRA).

Two per cent of migrants are assisted by BOESL. Although not very significant in percentages, the governmental agency is a very important channel for high-skilled workers and professionals.

Officially, migrant workers have to follow a pre-departure training course organized by $\mathrm{BMET}^{8}$ before they get clearance to go abroad. In the two-hour course, gen- 
eral information is given about the destination country, missions abroad, etc. Some recruitment agencies and NGOs (such as Shikkha Shastha Unnayan Karzakram (SHISUK)) also give additional pre-departure training. ${ }^{9}$

\subsubsection{Official bodies and policies regarding international migration}

Until 2001, the Ministry of Labour and Employment was responsible for international labour migration. At the end of 2001 a new Ministry was created at the demand of expatriate Bangladeshis and migrant workers. The new Ministry of Expatriate's Welfare and Overseas Employment (MEWOE) is entrusted with protecting the rights and the interests of migrants in the host country, as well as in Bangladesh when they return or are about to leave. More specifically, its tasks consist of (1) ensuring the welfare of the expatriates; (2) facilitating overseas employment; (3) increasing the resource capabilities to make them competitive; (4) developing the skills of the labour force.

Two other governmental bodies fall under the MEWOE. BMET is responsible for executing plans and policies of MEWOE aimed at enhancing labour migration and protecting the migrants' welfare, as well as training labour migrants. These tasks also involve controlling and monitoring the activities of recruiting agencies.

BOESL is responsible for enhancing and processing all foreign employment demands from other governments or individuals. In addition, it promotes the employment of Bangladeshis in other countries (Akbory, 2003; INSTRAW and IOM, 2000; MEWOE 2002; personal interviews). ${ }^{10}$

Migration Policies of the Government of Bangladesh are mainly oriented towards labour migration. ${ }^{11}$ From 1976 onwards, the Government of Bangladesh took an active role in stimulating labour migration. Like other Asian countries, labour migration was seen as a way to alleviate unemployment and to generate foreign income (Jureidini, 2001). The most important piece of legislation designed to control labour migration is the 1982 Immigration Ordinance. Under this Ordinance, the government body responsible for overseas labour migration is authorized to promote and regulate emigration. The importance of labour migration was also highlighted in the subsequent five-year plans of Bangladesh, which covers all aspects of development. In this plan, overseas labour migration is being promoted (Morshed, s.d.).

An exception to this is made for female labour migration. In 1981, certain categories of female workers - in particular unskilled and semi-skilled labourers - were barred from going overseas. The underlying motivation consisted of protecting women's safety and dignity. Although the ban was relaxed in 1988, it was re- 
imposed again in 1997. This time even some categories of professional women were not allowed to work overseas (INSTRAW and IOM, 2000). However, the government and the new Ministry have recently begun to explore ways in which this restriction may be relaxed and are progressively working towards removing the restrictions. ${ }^{12}$

\subsection{The extent of migration}

Unfortunately, there are no official figures (only estimates) regarding the Bangladeshi diaspora in industrialized countries. As mentioned earlier, official data only exist on labour migrants. Official data of BMET show that between 1976 and September 2004 more than 3.8 million migrant workers from Bangladesh had been registered. This number can give a distorted view. On the one hand, one single migrant worker can account for more than one registration if he or she has emigrated and returned more than once in the 29-year period - although Bangladeshis who temporarily returned to their home for short visits represent only one migration. On the other hand, irregular labour migration is not captured by the official data.

Figure 1 shows that the number of officially recorded labour migrants has steadily increased in the last 29 years, from around 6,000 annually in 1976 to more than 200,000 annually at the end of the 1990s and beginning of the twenty-first century (except 2001). ${ }^{13}$ This last figure represents about 4 per cent of the total workforce. Besides the competition from the new labour-sending countries and the military and economic crises in the Middle East and South-East Asia (see above), the fluctuation in the official migration flow of the $1990 \mathrm{~s}$ is also explained by labour migration policies in the destination countries, and by the fluctuating importance of irregular migration. In 1997, for instance, the Malaysian government legalized 150,000 Bangladeshi labour migrants (Siddiqui, 2003).

The most popular destination country in the Middle East is Saudi Arabia (see Figure 2). Half of all Bangladeshi migrant workers have migrated to this country in the last 29 years. Saudi Arabia is followed by the UAE (with about 480,000 migrants) and Kuwait (more than 380,000 labour migrants officially), Oman (more than 230,000), and - to a lesser extent - Bahrain, Qatar, Libya and Iraq (until the Gulf War of 1991). In South-East Asia, Malaysia has been the main destination country with officially more than 250,000 Bangladeshis labour migrants during the same 29-year period. ${ }^{15}$ Singapore and to a much lesser extent South Korea receive a significant number of labour migrants as well. In the last years, the most popular countries remained Saudi Arabia, the UAE and Kuwait, while the South-East Asian countries are gaining ground. 
FIGURE 1

EVOLUTION OF TOTAL NUMBER OF

OFFICIALLY RECORDED BANGLADESHI LABOUR MIGRANTS

(SEE ANNEX C FOR DETAILED FIGURES)

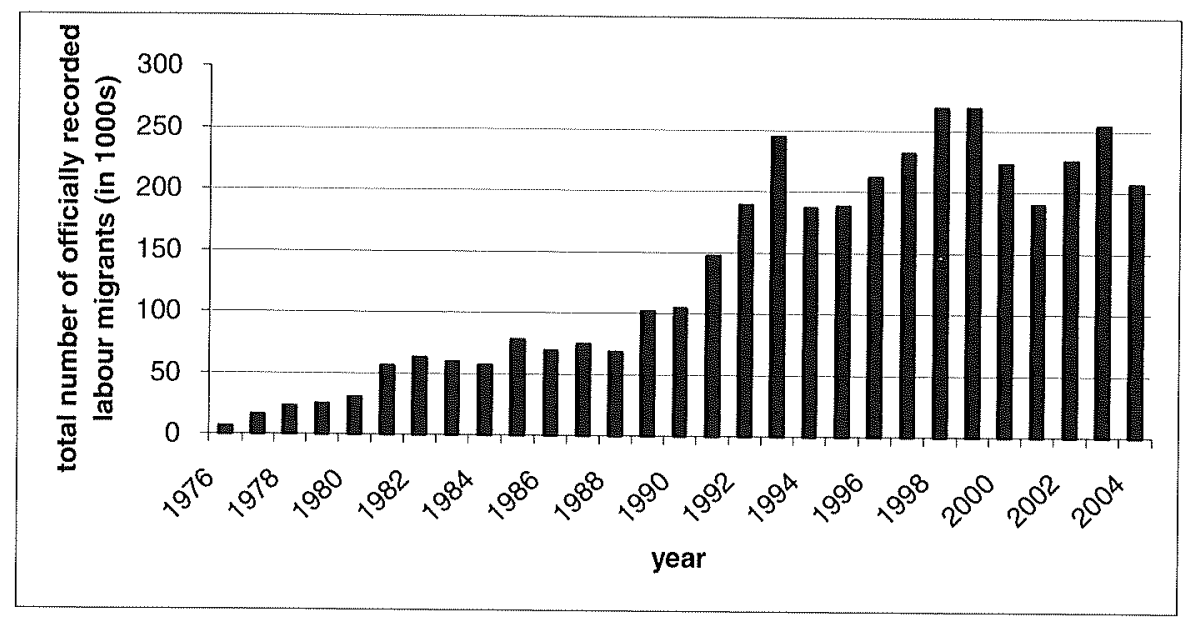

Source: BMET figures of $2004 .^{14}$

FIGURE 2

NUMBER OF OFFICIALLY RECORDED LABOUR MIGRANTS

FROM BANGLADESH ACCORDING TO DESTINATION COUNTRY, 1976-2004

(SEE ANNEX C FOR DETAILED FIGURES)

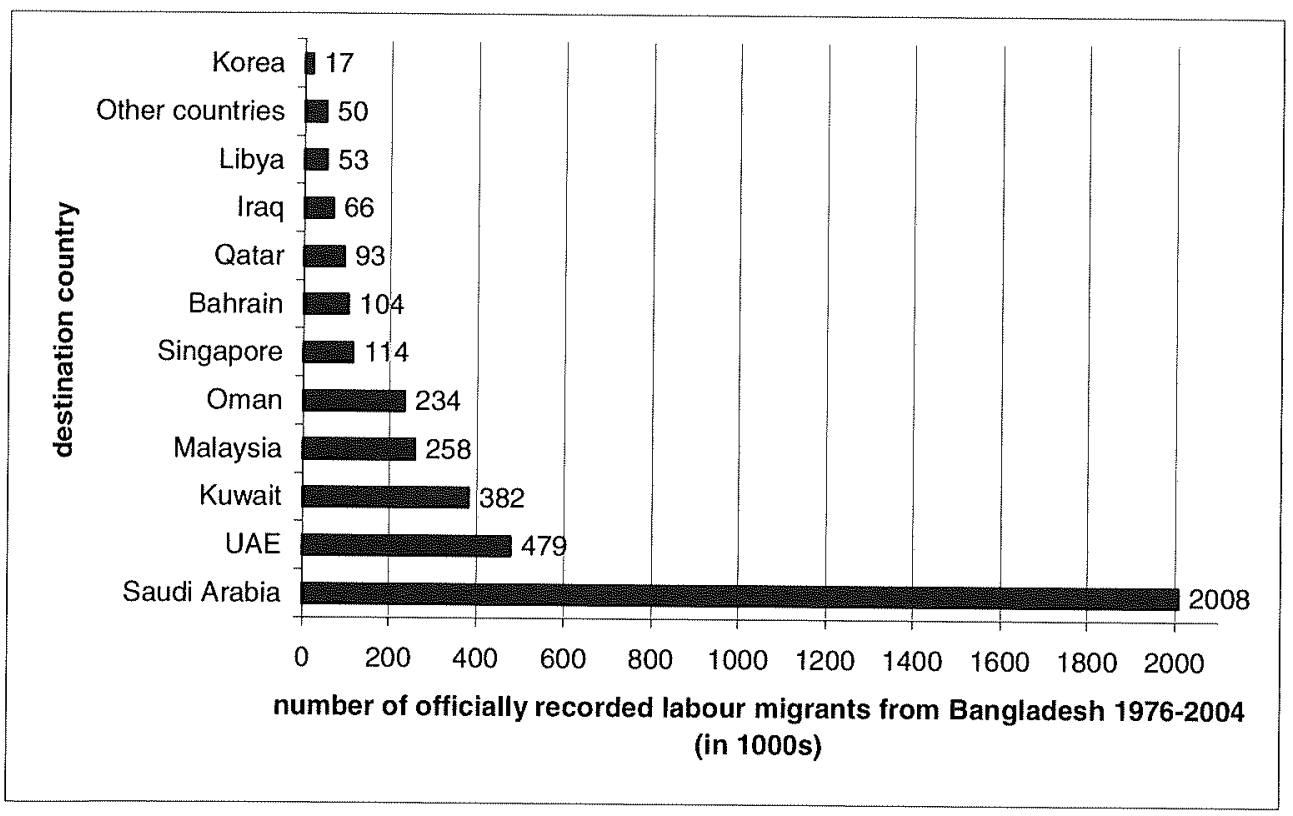

Source: BMET figures of $2004 .^{16}$ 
According to an educated guess of government officials and migration experts, almost 1.2 million Bangladeshis live in industrialized countries. These include undocumented and documented migrants. Altogether some 500,000 Bangladeshis live in the UK and about the same number in the USA. Government officials estimate that Italy, Canada, Japan, Australia and Greece each host more than 10,000 migrants (see Table 1) (Siddiqui, 2004b).

TABLE 1

NUMBER OF BANGLADESHI IMMIGRANTS IN INDUSTRIALIZED COUNTRIES

\begin{tabular}{|l|c|}
\hline Country & Number of Bangladeshi immigrants \\
\hline UK & 500,000 \\
USA & 500,000 \\
Italy & 70,000 \\
Canada & 35,000 \\
Japan & 22,000 \\
Australia & 15,000 \\
Greece & 11,000 \\
Spain & 7,000 \\
Germany & 5,000 \\
South Africa & 4,000 \\
France & 3,500 \\
Netherlands & 2,500 \\
Belgium & 2,000 \\
Switzerland & 1,400 \\
\hline
\end{tabular}

Source: Educated guess made by government officials and migration experts of Bangladesh who have first-hand experience with the immigrant country (Siddiqui, 2004b: 17-18).

\subsection{Who migrates?}

It is quite difficult to obtain a clear and complete picture of the migrant worker, due to the lack of data, as discussed earlier.

In terms of gender the overwhelming majority of Bangladeshi migrant workers are male, according to official data of BMET. Only 17,784 women migrated officially between 1991 and 2003. This very low figure represents less than 1 per cent of the total labour migration during that period. However, real figures will be much 
higher, but these are not available as many women leave through unofficial channels due to the restrictions that are in place. In an issue of the South Asia Tribune of 2002, an unnamed official of BMET is quoted. According to this unchecked information "45,000 Bangladeshi women have left to work illegally in Persian Gulf countries since 1998" (Islam, 2002). The under-representation of women in official statistics has a number of reasons. Firstly, the successive Bangladeshi governments have restricted labour migration of professional and skilled women a number of times, and banned the migration of unskilled women. Secondly, the bureaucratic red tape might be of greater hindrance for women than for men. Both factors have prompted women to use informal channels to facilitate migration (INSTRAW and IOM, 2000).

In the UK and the USA, the gender ratio between male and female migrant workers is far less outspoken than in the Middle East and the newly industrialized countries. From the 1970 s onwards, the ratio was more or less $60-65$ per cent men and 35-40 per cent women. In the UK, for every 100 female new entrants, 109 male migrants entered the country from Bangladesh (Siddiqui, 2003). The 1991 census in the UK showed that there were 1,091 males for every 1,000 females in the Bangladeshi ethnic group (Siddiqui, 2004b).

As stated earlier, data on the age of migrant workers are hard to find. Some micro-level studies (see Hossain, 2001; Siddiqui, 2003) indicate that most labour migrants are young, more specifically between 15 and 30 years of age.

The Bangladeshi diaspora in the UK and the USA belongs to one of the youngest population groups in both countries. For instance, twice as many ethnic Bangladeshis are younger than 15 years in comparison to the ethnic white population in the UK (Siddiqui, 2004b).

According to micro-level studies, most migrant workers have a low educational background or are illiterate (Hossain, 2001; Siddiqui, 2003). More than half the Bangladeshi labour migrants are unskilled or semi-skilled, while the proportion of professionals is very low (about $2 \%$ in 1999 for instance).$^{17}$ Over the last 25 years about 44 per cent of all recorded temporary labour migrants were unskilled, 22 per cent were semi-skilled, 30 per cent skilled, and only 4 per cent were professionals. Siddiqui and Abrar (2001) and INSTRAW and IOM (2000) explain this by referring to the demand in destination countries for maintenance and domestic work, especially after the big infrastructure development in the Arab countries in the 1970s. The authors add that Bangladesh did not invest enough in human resource management. As a consequence, other countries gained ground in the market for skilled and professional migrants. Men mainly work in the construction sector, cleaning, maintenance work, services and farming in the Middle Eastern and South-East Asian countries 
(Hassan, 2000). Women, on the other hand, work mainly as garment workers, cleaners, housemaids and nurses, and in the manufacturing industry in Malaysia (official data of BMET). Unrecorded female migrants are mainly employed as domestic workers (INSTRAW and IOM, 2000).

The older diaspora in the UK also has little educational background, although the younger generations go to school or even pursue higher education. Still, the educational level of this community is lower in comparison with the ethnic white, Chinese and Indian communities. Ethnic Pakistani and Afro-Caribbean communities show similar or lower educational attainment levels ${ }^{18}$ (Ballard, 2001; Bradley and Taylor, 2000). In the USA a different picture emerges. According to Siddiqui (2004b), the expatriate Bangladeshi population shows very high levels of education. This is explained by the fact that many Bangladeshis came to the USA to pursue higher education.

In the UK about two-thirds of Bangladeshi men over 16 years do manual work, while 16 per cent are employed in professional and managerial positions (Siddiqui, 2004b). The success of so-called Indian restaurants in East London, most of which are owned and exploited by Sylheties, offer most employment opportunities for young Bangladeshis. According to Ballard (2001) over 60 per cent of Bangladeshi men aged between 20 and 30 are currently employed in the catering industry. Still, unemployment rates are relatively high compared with other ethnic population groups in the UK. In the USA, on the other hand, most Bangladeshis occupy professional or technical positions (Siddiqui, 2004b).

\subsection{Obstacles to the migration process}

Before continuing with the main topic of this report - remittances - we will look at the most important problems that Bangladeshi international migrants are faced with. Short-term labour migrants to the Middle East and South-East Asia experience a number of structural problems at different stages in the migration process and in the host countries (see, for instance, Afsar, 2001; Rahim, 2001; and Siddiqui, 2002a and 2003). The problems listed here will help us understand the dynamics of remittances.

\subsubsection{Cost of migration}

One of the first problems that migrants face prior to migration is the cost of migration. The migration process in Bangladesh is relatively expensive. Costs include airfare, passport, visa, insurance, medical check, clothes, payment to recruitment agencies, etc. Total expenses can amount to US\$ 2000 or more. ${ }^{19}$ Although 
migrants use their own savings to fund the trip, they need additional funds. The most cited resources in surveys (INSTRAW and IOM, 2000; Abdul-Aziz, 2001; Siddiqui and Abrar, 2001; Afsar, 2001; Afsar et al., 2002; Mahmood, 1992), include support - either gifts or loans - from family and friends, loans from banks or private money lenders, selling assets or land. Interestingly, the interest rates charged by banks are often higher when the purpose of the trip is known (INSTRAW and IOM, 2000). As a consequence, many families accumulate debts in order to send a family member abroad. Furthermore, these families and migrants also have to use the remittances to repay the debts they have made during the migration process. In the last years this situation has only worsened. The demand for labour migrants has been decreasing in the Middle East and South-East Asia, while the availability is very high. This has put a downward pressure on the wages. In addition, the employers in these host countries used to pay part of the travel expenses, while now the travel costs have to be borne entirely by the migrants themselves. For a number of Bangladeshis the financial costs of migrating even outweigh the gains (see Afsar et al,, 2002, and INSTRAW and IOM, 2000).

\subsubsection{Exploitation by recruitment agencies and foreign employers}

Secondly, during the migration process migrant workers sometimes become victims of exploitation by malevolent recruitment agencies, foreign sponsors or employers. Siddiqui et al. (1999) list a number of examples of exploitation by authorized recruitment agents and foreign sponsors (see Table 2).

Afsar (2001) confirms many of these issues, adding to it that women workers are often subject to discriminatory wages, frequent salary cuts, verbal abuse, flogging and restricted mobility in the Middle East. ${ }^{20}$ 


\section{By recruitment agencies}

Collecting more service charges than permitted under the law.

Recruiting workers for positions which are not actually available, resulting in the workers getting stranded on arrival in a foreign country.

Collecting money for overseas placement but not actually sending the worker abroad.

Recruiting worker for a wage which is too low.

\section{By foreign sponsors or employers}

Changing the employment agreement on arrival to the disadvantage of the worker.

Offering a job other than the one contracted through recruiting agencies in the country of origin.

Non-payment of salary, or non-payment on time, or partial payment.

Not providing board and lodging or allowance as agreed upon.

Refusing to provide medical facilities.

Threatening to involve criminal charges.

Sexual exploitation.

Overtime work without compensation.

Refusing to hand over passport or other travel documents to the worker.

Source: Siddiqui et al., 1999: 32-33.

\subsubsection{Xenophobia towards Bangladeshis in host countries}

In the host countries Bangladeshi labour migrants see themselves faced with racism. Jureidini (2001) has extensively elaborated on xenophobia of migrant labourers in the Middle East, especially domestic workers. Abdul-Aziz (2001: 13) concluded from his research that Bangladeshis in Malaysia are perceived by their employers as the lowest stratum in comparison to other nationalities such as Indonesians. Gender discrimination renders the situation for women even more precarious.

Xenophobia partly explains the restrictive policies towards labour migrants in many Middle Eastern and South-East Asian host countries. Rahim (2001) lists a number of examples in his study of the regime for Bangladeshi migrant workers. For instance, according to the author, mass deportations from Middle Eastern countries are not uncommon. Also in Malaysia deportations, detentions, arrests and violence against migrant workers have been documented. In her documentary "My Migrant Soul", Kabir gives a detailed account of a worst case scenario. She tells the 
real story of a Bangladeshi migrant worker who went to Malaysia to work in the construction industry. Once there his passport got stolen and he ended up doing illegal work. Caught by the police he died in a detention camp. His wife and mother only found out after a long and strenuous process, in which they tried to get news about him from official channels and the recruitment agency. Unfortunately this is not an isolated case. ${ }^{21}$

\subsubsection{Lack of appropriate policy measures to protect rights of labour migrants}

None of the major destination countries in these regions have ratified the 1990 International Convention on the Protection of Rights of All Migrant Workers and Members of their Families. Other instruments for the protection of migrant workers' rights have been signed by only a few countries (see Siddiqui, 2003). Because they are not allowed to form any associations or unions, it is very difficult for migrants to voice their needs and problems.

Consequently Afsar formulates her critique as follows (2001: 5):

Asian immigrant can best be described as a "necessary evil" from the GCC 22 point of view. This is because Asians contribute more than 80 per cent of the total labour force for these nations and yet they are cheaper, less politically threatening and can be more effectively exploited through policies of deliberate discrimination than Arab migrants. In implementing labour policies, the Gulf States partly followed the Western policy of extracting labour from migrants without engaging them fully as human beings.

Besides the destination countries, the Bangladesh government also lacks an appropriate policy for the protection of migrant workers' rights. The Bangladesh government has not ratified the above mentioned UN Convention (see Rahim, 2001, and UN, 2002). In the subsequent five-year development plans of Bangladesh for instance, labour migration has been promoted without giving much attention to the welfare of migrant workers (Morshed, s.d.; Rahim, 2001). Female labour migration, on the other hand, has been banned a couple of times - with the exception of highly qualified professionals. The underlying motivation consisted of protecting women's safety and dignity. However, a substantial number of women are now travelling overseas as undocumented migrants with no protection whatsoever (INSTRAW and IOM, 2000).

One of the most important measures taken to enhance the well-being of migrant workers is the Wage Earner's Welfare Fund, created in 1990. The Fund is financed by a fixed amount of money that migrants have to pay in order to get clearance from 
BMET, by interests earned from the deposits from recruiting agencies, and by fees paid by migrants to overseas missions to obtain visas and passports, and by personal and institutional contributions. The Fund is used for language courses for aspiring migrants, pre-departure training for migrant workers, a welfare desk at the airport and the repatriation of deceased workers (Siddiqui, 2003; MEWOE, 2002). Furthermore, educational facilities have been funded by the welfare fund, as well as transport facilities for migrants to and from the airport. For the future, a dormitory is planned near the airport to facilitate the migrants' travel process. However, the Welfare Fund has received a considerable amount of critique. Not only have there been signs of its misuse (The Bangladesh Observer, 1999), but also the migrants' lack of representation in the decision-making body has been contested. Indeed, besides ministries, only BAIRA has a seat on the board of directors. According to existing labour migrant associations, the allocation of the Fund has inadequately addressed the needs of the migrants. ${ }^{23}$

\subsubsection{Weak representation of migrant workers}

In Bangladesh labour migrants lack proper bodies to represent them. Trade unions do not consider migrant workers as one of their constituencies (Siddiqui et al., 1999), although this would change in the future, Mr Rahman, President of Bangladesh Sanjukta Sramik Federation (BSSF) told us in a personal interview. Associations that represent migrant workers are the Welfare Association of Repatriated Bangladeshi Employees (WARBE) and the Bangladeshi Ovhibashi Mohila Sramik Association (BOSMA), formerly known as the Bangladeshi Women Migrant Association (BWMA). WARBE was created in 1997 by a returnee migrant with the support of the NGOs SHISHUK and the Christian Commission for the Development of Bangladesh (CCBD). It targets migrant workers and acts as advocator and tries to empower them and promote their rights. BOSMA was created in $1998^{24}$ by a group of returned women labour migrants. Together they only represent some 4,000 migrant workers or returnees. Both associations are characterized by a lack of financial means and organizational capacity. In addition, they occupy a relatively weak position in the decision-making process, compared to NGOs, governmental bodies and recruiting agencies. Due to the low socio-economic status of most labour migrants and their rural background, they do not form a stable and sufficient financial resource base, which might be the reason for the low number of associations. In addition, donor organizations do not focus on migrant associations. Lastly, they are barely recognized by the government as the organization representing the migrant communities. Some government officials did not even know of their existence, and another one argued that "the migrants are there [in the destination countries] while the organizations are based and work here [Bangladesh]. So they cannot represent the migrants at all". For this reason the association WARBE had to term itself 
"repatriated Bangladeshi employees" instead of "migrant labourers". Notwithstanding these bottlenecks the migrant associations have put together a number of projects and initiatives to improve the situation of migrant workers.

\subsubsection{Limited attention given to migrant workers by civil society}

Considering the scale of labour migration, civil society associations have dedicated relatively little attention to protecting the rights of migrant labourers (Siddiqui, 2003). Besides the migrant associations, the NGO SHISUK is involved with predeparture orientation and migrant returnee projects (see Chapter Five). Ain O Shalish Kendra (ASK), Bangladesh Legal Aid Service Trust (BLAST) and Bangladesh Society for Enforcement of Human Rights (BSEHR), as well as IAS and the Newham Bengali Community Trust (NBCT) in Sylhet provide legal aid to migrants.

International organizations and donors are also characterized by a lack of interest in the issue. Only IOM and to a lesser extent ILO, DFID and Action Aid have commissioned studies on the issue. However, in recent years attention to the problems of labour migrants seems to have been increasing.

The same applies to research institutes. Only RMMRU and BIDS have focused considerably on the rights of labour migrants.

Furthermore, Siddiqui (2003) argues that the workings of civil society and government institutes are characterized by a lack of cooperation and coordination, both in regard to policy formulation, and the implementation of projects. 


\section{VOLUME AND DYNAMICS OF REMITTANCES}

\subsection{Volume and origins of formal remittances}

\subsubsection{Volume of formal remittance flow}

According to official data of the Bangladesh Bank and BMET, Bangladesh received about a total of US\$30,400 million in remittances between 1976 and 2004 . Figure 3 shows that the official flow of remittances to Bangladesh has increased dramatically in the last 29 years. While in 1976 only US\$ 24 million entered the country through official channels, this number stood at more than US\$2,600 million in 2002. Until the early 1980s remittances increased steadily, reaching around US\$ 630 million in 1983. The next year the remittance flow decreased, but from 1986 onwards the growth started again. In the last 12 years a major increase in the amount of remittances has taken place, from just under US $\$ 800$ million at the end of 1990 s to more than US $\$ 2,000$ million in 2001 and even surpassing US $\$ 3$ billion two years later. In 2003, official remittances stood at US $\$ 3.18$ billion according to BMET figures. In the first nine months of 2004 , US $\$ 2.35$ billion in official remittances entered the country.

According to Berlage et al. (2003), who have compiled data from a number of information sources, in 1999 Bangladesh was the sixth remittance receiving country in the world in absolute figures. Based on her information, Kuddus (2003) reports that the remittance flow to Bangladesh represents 2 per cent of the global remittance flow.

Offering an explanation for the evolution in remittances is not easy. Of course the flow of remittances is very much linked to the emigration rate. The increase of labour migration to the Middle East in the second half of the 1970s has had its effects on the remittance flow. However, the correlation is not a straightforward one. There is always a time lag: the migrant needs time and money to settle him or herself in the host country. Siddiqui (2003) argues that the emigration rate has been higher than the growth of remittances. She identifies lower wage rates as explanatory factors: Bangladesh has recently experienced emigration of more unskilled and semi-skilled migrants, whose wages are lower in comparison with the previous wave of skilled emigrants, and simultaneously wage rates in destination countries have fallen drastically in the last decade. 
Political turmoil in the countries of destination has also affected the remittance flow. The sluggish growth in the mid-1980s may be attributed to the Iran-Iraq war of that time. A similar correlation might exist between the slow growth rate at the beginning of the 1990s and the Gulf War (Afsar et al., 2002). It is also assumed that the recent increase is a result of more people sending money through official channels, given the increased attention to anti-terrorism policies.

FIGURE 3

REMITTANCE FLOW TO BANGLADESH (1976-2003) (SEE ANNEX C FOR DETAILED FIGURES)

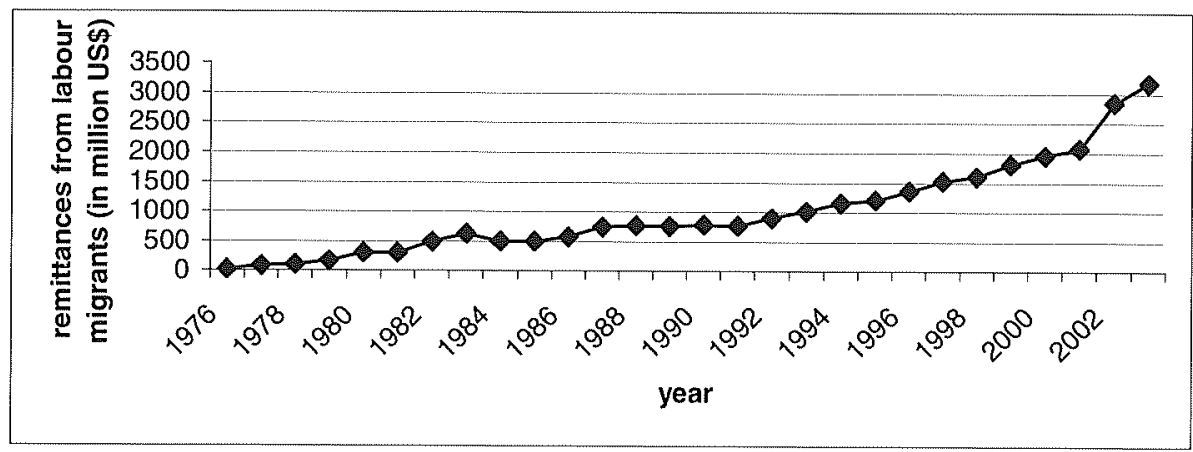

Source: BMET figures of $2004 .^{25}$

Puri and Ritzema (1999) list a number of other factors that influence the size of remittances, such as exchange rates, macroeconomic policies, the marital status of the migrant, and the economic activity in the host or sending region or country. Furthermore, the figures of the Bangladesh Bank only reflect the formal remittance flow. We will elaborate later on the importance of the informal remittance.

\subsubsection{Origins of formal remittances}

Most of the international remittances come from the Middle East (see Figure 4). In the last six years, Saudi Arabia alone accounted for more than 40 per cent of the official remittance flow. A very important share of remittances comes therefore from temporary migrant labourers. Between 1997 and 2004 (financial years), almost US\$ 6,900 million were remitted from Saudi Arabia, more than US\$1,900 from Kuwait, and more than US\$1,400 million from the UAE. The shares for Qatar, Bahrain and Oman amounted to several hundreds of million US\$. Officially, more than US\$300 million were remitted from Malaysia. However, the importance of the diaspora should not be underestimated. Over the years, the USA has become the second largest remittance sending country. Between 1997 and 2002, 14 per cent of 


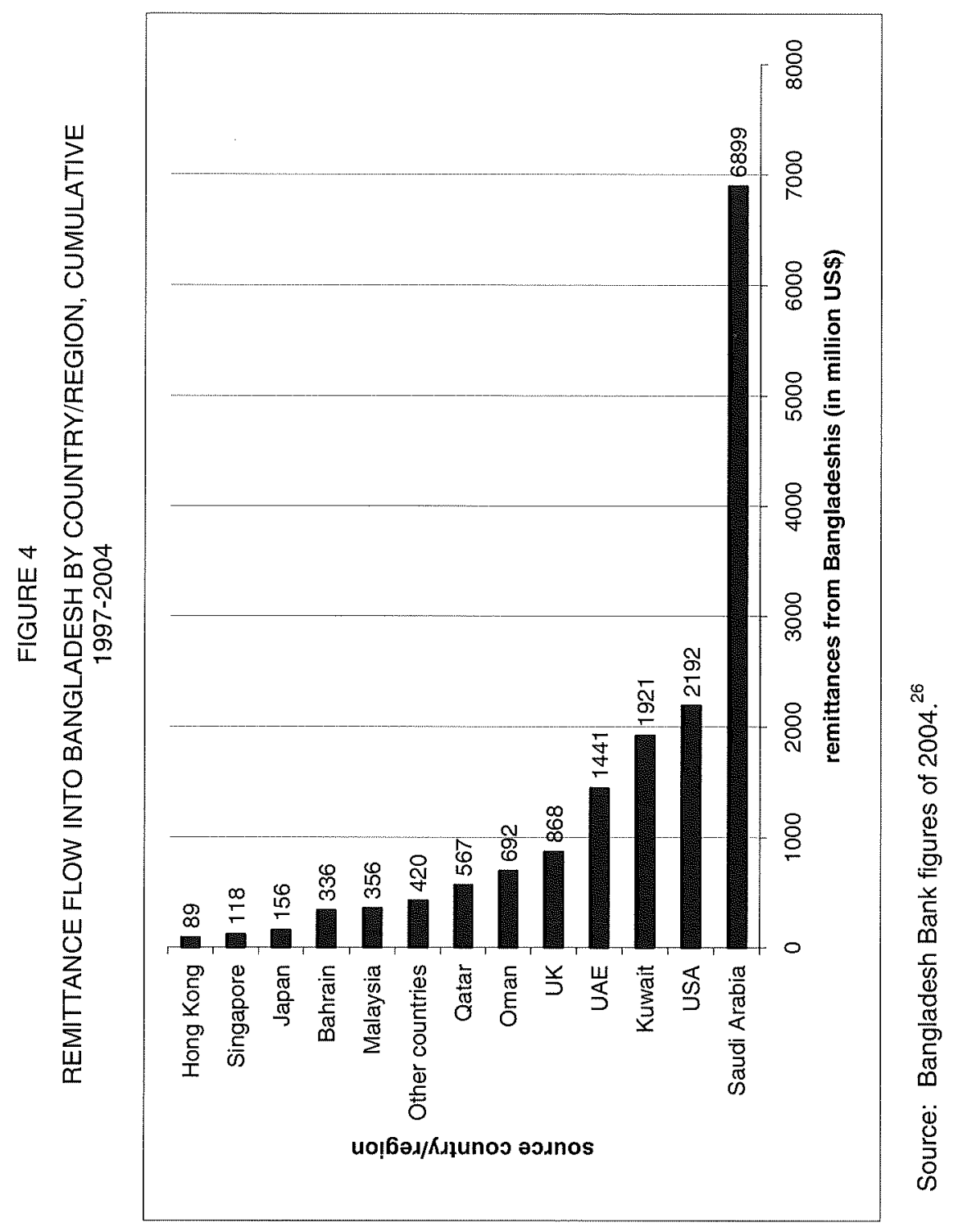


all the official remittances (i.e. almost US $\$ 2,200$ million) coming into Bangladesh originated in the USA. The UK, another important country for long-term Bangladeshi migrants, accounts for 5 per cent of the remittance flow (i.e. almost US $\$ 900$ million) in the same period.

When comparing countries in terms of destinations for migrant labourers and as sources of official remittances, it can be concluded that the picture does not seem completely coherent. For example, the UK and USA are major remittance sending countries, while other countries register more new immigrants. A number of explanatory factors for this discrepancy have been mentioned above.

\subsection{Remittance channels and methods of transfer}

\subsubsection{Formal transfer methods}

As mentioned earlier, the statistics of the Bangladesh Bank only reflect the formal remittance flow. According to a study of Mahmud (cited in Puri and Ritzema, 1999) informal remittances account for 20 per cent of the total amount of remittances in Bangladesh. A more cited figure in the interviews ${ }^{27}$ is 40 per cent to as much as 50 per cent. Hence, a significant number of financial transfers do not appear in the official data. ${ }^{28}$

A study of Siddiqui and Abrar (2001) among labour migrants to the UAE revealed that 46 per cent of the total volume of transactions has been channelled through official methods (defined below), around 40 per cent through the hundi system (see below), 5 per cent through friends and relatives and 8 per cent was hand carried by migrants themselves.

Official channels refer to demand drafts issued by a bank or an exchange house, traveller's cheques, telegraphic transfers, postal orders, account transfers, automatic teller machine (ATM) facilities and electronic transfers. Of these, demand drafts are most popular (Siddiqui and Abrar, 2001). Expatriates and migrants using official channels have quite a few options. Firstly, they can send money from a bank in the destination country to a bank in Bangladesh. The former bank must have a correspondent relationship with the latter. Secondly, they can send money through branches or subsidiaries of a Bangladeshi bank in the destination country. Thirdly, money can be remitted through exchange houses or banks in the destination country with which a Bangladesh bank has a taka drawing arrangement. Due to the direct link between the bank or exchange house in the destination country and the one in Bangladesh in the last two cases, the transaction time should be shorter. 
The Bangladesh financial system consists of the Bangladesh Bank (BB), four nationalized commercial banks (NCB), five government owned specialized banks, 30 private commercial banks (PCB), ten foreign banks and 28 non-bank financial institutions. ${ }^{29}$ The $\mathrm{BB}$ is the central bank of Bangladesh, which supervises and regulates all the other banks. In order to deal with foreign exchange, banks need authorization from the BB. Banks that are allowed to deal with foreign exchange either have their own exchange branches in the destination countries or link up with international banks or money exchange companies, like Western Union. Importantly, private banks are not allowed to have branches in cities abroad whereas NCBs already have branches. However, they can have correspondent banks.

While all four NCBs, Janata, Sonali, Pubali and Agrani Bank, have branches abroad or are linked up with other banks, only one specialized bank, i.e. Bangladesh Krishi Bank, and half of the PCBs have similar arrangements. Krishi Bank was established to meet the credit needs of the agricultural sector.

None of the non-bank financial institutions are allowed to deal with remittances. These include the micro-finance institutions (MFIs) such as Grameen Bank, BRAC, ASA, and Proshika. Most of these institutions have an explicit social agenda and cater to the needs of the poorest section of the population. Mostly they provide credit to women. Recently, BRAC created the BRAC Bank. Importantly, this is not an MFI, but a PCB. However, it makes use of the vast network of the MFI BRAC. Currently, MFIs are not allowed to make financial transactions and deal with foreign exchange, making the involvement of MFIs in remittance transfer very difficult.

Figures of BRAC Bank ${ }^{30}$ show that the majority of official remittances is channelled through NCBs (about 58\%), while PCBs dealt with 38 per cent, foreign banks with about 3 per cent and specialized banks with less than 1 per cent of the remittance flow in 2003. On the basis of an interview with the governor of BB, Siddiqui and Abrar (2001) come to quite different figures for 2000. According to the governor of $\mathrm{BB}$, about 73 per cent of the remittances were channelled through official banks, and more than 26 per cent through PCBs. In terms of volume of remittances, the most important commercial bank would be Islami Bank of Bangladesh Limited (IBBL). Other noteworthy PCBs in terms of outlets abroad include Uttara Bank, Arab Bangladesh Bank and National Bank Ltd.

\subsubsection{Informal method: hundi}

As the figures cited above show, the so-called hundi system is the most important informal way in which money is transferred to Bangladesh. ${ }^{31}$ In the hundi system the 
migrant gives money to an intermediary, who contacts an agent in Bangladesh. The agent in Bangladesh is responsible for giving the equivalent of the money that the migrant has given to the intermediary to the recipient in Bangladesh. An informal exchange rate is used to determine the amount of money the recipient gets. The recipient can take the money from the agent by using a code that s/he receives from the migrant. Because there are no official documents used in the process - although informally it is often documented - the system is clearly based on trust (Berlage et al., 2003 and El-Qorchi, 2002). ${ }^{32}$

\subsubsection{Comparing formal and informal methods}

Several authors have compared the official and informal channels in Bangladesh (for instance, Siddiqui and Abrar, 2001; Murshid et al., 2002; INSTRAW and IOM, 2000). A study of INSTRAW and IOM (2000) indicates that women make more use of official channels than men. 82 per cent of the interviewed migrant women told the researchers that they used official channels to transfer money. The researchers attempt to explain this gender difference by referring to the potential higher risk adversity of women and their limited access to informal channels in comparison to men.

In general hundi is faster than official channels. Migrant families often need the money on short notice; therefore they need a fast money transfer system. Secondly, hundi is often cheaper, because there are hardly any commission fees. Thirdly, depending on the country, the exchange rates may be higher than official transfer methods. Fourthly, because of the limited use of paper work, hundi is easier to use for a significant number of Bangladeshis who are not familiar with banking facilities. In contrast to the official banks, hundi is accessible in remote areas. Lastly, hundi offers more confidentiality than official channels. This can also turn against the hundi practices. Following the terrorist attacks on 11 September 2001, hundi links have been made between hundi and terrorist networks, causing governments to restrict the practices of these informal channels (Black, 2003). The most frequently quoted drawback of the hundi system is that it can be less reliable than official channels, and money may get lost. However, as Murshid et al. (2002) note, in the official transfer system demand drafts may also get lost, banking services may be poor and post offices and bank officials may seek bribes from relatives of the migrants. Therefore, hundi systems may be trusted more than official channels.

\subsection{Utilization of remittances}

Focusing on the individual migrants, a more detailed and heterogeneous picture of the remittance dynamics emerges. 
Roughly, earnings of migrants can either be consumed, invested or saved in the country of destination, or remitted to the home country and subsequently saved, invested or consumed.

The proportion of the income that migrants remit is dependent on a number of factors. In general Black (2003) states that:

\begin{abstract}
(..) remittances are likely to be higher in situations where the migrant leaves broadly for economic reasons than political or social reasons, where they have temporary rather than permanent resident status, where they are young, but married with family left behind at home, and that remittances will increase as emigrant wages increase although at a certain point, further increases in wage levels do not seem to translate into higher remittances.
\end{abstract}

Studies in Bangladesh seem to confirm these findings, although it is very difficult to make generalizations. A study by Mahmood in 1991 of 510 Bangladeshi returnees from Japan who had households in Munshgonj and Dhaka revealed that migrants send up to 80 per cent of their income home (cited in Murshid et al., 2002). Siddiqui and Abrar's (2001) field work revealed that a typical migrant remits about 56 per cent of his income (own emphasis), while INSTRAW and IOM's (2000) study showed that temporary women migrants to the Middle East remit on average 72 per cent of their income. ${ }^{33}$ These figures are mainly applicable to labour migrants. On the other hand, Ahmad and Zohara (1997) state for Sylheties migrant workers that "many migrant workers from Sylhet division are known to have large savings abroad" (own emphasis). Without giving any tangible evidence of this statement, Prof. Dr Ahmad of BUP and others like Mr Chowdhury of the Sylhet Investors Forum repeated these findings in personal interviews. Despite the lack of available figures, it can be argued that the diaspora should remit on average a smaller proportion of their income compared to the labour migrants. The surveys of Siddiqui (2004b) and Kuddus (2003) indeed indicate that expatriates living in the USA and the UK tend to save more abroad. A possible explanation for this is that the diaspora is more attached to their destination country than the short-term labour migrants. They establish a family, a social network, a business, etc. The future of these families lies in the destination country and consequently they remit less of their income.

Looking at the dynamics and utilization of remittances, four types of transfers can be distinguished:

2004 Individual transfers from migrants to children, wives, family members or friends 2005 Individual transfers by migrants in order to save or invest in home country 2006 Individual transfers by migrants to charity or community development 2007 Collective transfers to charity or community development 


\subsubsection{Individual transfers from migrants to children, wives, family members or friends}

Micro-level studies in Bangladesh, as well as a report of the International Group (IDG) of the British-Bangladeshi Professionals Association (BBPA) (2003) and our interviews elucidate that this is by far the most common structure.

Important to note is that - although in a lot of micro studies the household is the focus of attention - not every member receives an equal amount of remittances, or even has access to remittances. The study of Siddiqui and Abrar (2001) illustrates this. In the majority of the 100 researched families, only one person received remittances, while in only three families three people received remittances. In most families the father of the migrant received the money, followed by the wife, the mother and the brother. Interestingly, although 53 of the remittance senders were married, only 27 of the receivers were spouses. Also, according to a study of Mahmood (1991), most recipients of remittances were the fathers. In this case the father was followed by the brother and the wife. Regional variations seem to exist. In Noakhali the wife was the most important recipient, while in Chittagong it was the son.

\section{Why do migrants remit to their families and friends?}

Three main theoretical explanations exist why migrants remit to family members or to other people (Black, 2003; Lucas and Stark, 1985, cited in El-Sakka and McNabb, 1999). Firstly, there is the concept of altruism. In this case the migrant's aim is to increase the well-being of the family by providing additional income. A second reason can be self-interest. The migrant remits for instance to increase his/her opportunities to subsequently inherit. Thirdly, remittances can be seen as a mutually beneficial arrangement between the family and the migrant. In this context, remittances can act as a repayment for past expenses of the family to finance the migration. On the other hand, remittances can also serve as a diversification strategy or risk-sharing strategy (see also Chimhowu et al., 2003). The family of the migrant and the migrant him/herself work in different areas, thus providing alternative sources of income. Some families have several members working as migrant labourers in different countries.

Depending on the type of receiver, the reason for remitting will differ. Kuhn (2001) argues for instance that remittances to parents act as a kind of social security system. When migrants marry, the amount of remittances tends to decrease and a larger proportion will go to the wife and children.

Another reason for sending remittances often mentioned by the interviewees ${ }^{34}$ was the pressure that the family exerts on the migrant. The expectations towards the 
migrant are often very high. Furthermore, the family is often not aware of the situation in which many labour migrants live and work. This has been exacerbated by the reluctance of many migrant workers to tell their family about the negative aspects of the migration process and their living conditions.

\section{How important are remittances for migrants' families?}

The importance of remittances for the receiving family cannot be underestimated. Remittances form a part of the earnings of the family. The study of Siddiqui and Abrar (2001) revealed that 51 per cent of the total earnings of families in the study is derived from remittances. Mahmood (cited in Murshid et al., 2002) found that remittances of the Bangladeshi migrants living in Japan accounted for 70 per cent of household income on average. Ahmad and Zohara (1997) derived a similar percentage from their study in Sylhet. Afsar et al. (2002) observed in their study that over the years households with an overseas labour migrant become increasingly dependent on remittances. The level of income of the surveyed migrant households increased to 55 per cent.

\section{What do migrants' families use remittances for?}

Due to the lack of nationwide studies it is very difficult to determine the utilization of remittances. The only available studies are very region-specific micro-level studies (see Appendix A). In the following the findings of these studies have been compiled (see Table 3 ).

Like in many other countries, most surveys indicate that the majority of remittances are used for consumption (Siddiqui and Abrar, 2001; Afsar, 2003). Afsar (2003) even mentions percentages of 80 to 90 per cent. However, the literature also shows that there are ongoing discussions about what constitutes consumption. Some authors include land purchase and children's education, while others omit these, and include them with productive uses. It is therefore more useful to have a more detailed look at the expenditures without categorizing them as productive or non-productive.

Food and clothing feature highest on the list. Siddiqui and Abrar's (2001) study revealed a proportion of 20 per cent while in Murshid et al.'s (2002) survey 36 per cent of the remittances were spent on food alone. Families will first use remittances to meet their basic needs. When the income increases, the share expended on basic need items will decrease, as described by Engel's theory (cited in Afsar et al., 2002). The survey of Afsar et al. (2002) indeed confirmed this theory. Annual household expenditures increased by 22 per cent, while the expenditure share on food items decreased by about 5 per cent. 
TABLE 3

MOST OFTEN MENTIONED USES OF REMITTANCES BY FAMILIES OF LABOUR MIGRANTS IN THE STUDIES OF APPENDIX A

(the middle column refers to the lowest $\%$ cited in the micro-level studies, while the right hand column indicates the highest value found)

\begin{tabular}{|l|cc|}
\hline Purpose & $\begin{array}{c}\text { Minimum \% } \\
\text { of received } \\
\text { remittances }\end{array}$ & $\begin{array}{c}\text { Maximum \% } \\
\text { of received } \\
\text { remittances }\end{array}$ \\
\hline Food and clothing & 20 & $>1=36^{35}$ \\
Purchase of land & 3 & 40 \\
Home construction and repair & 2 & 30 \\
Repay loans & 10 & 19 \\
Marriage and ceremonies & 0 & 10 \\
Education & 0 & 5 \\
Savings & 3 & 7 \\
Funding other people's migration & 0 & 7 \\
Investment in business & 0 & 5 \\
Health care & 0 & 4 \\
\hline
\end{tabular}

Source: Compilation of studies listed in Appendix A.

A second important use of remittances is the purchase of land and home construction and repair. Murshid et al. (2002) stated that 15 to 40 per cent and 10 to 30 per cent is spent on each item respectively. Considering the scarcity of land in Bangladesh, land is the most profitable and safest investment in Bangladesh (Murshid et al., 2002). IDG BBPA (2003) adds that the many opportunities for rental make property a very good investment. The property can be used to provide support for family members or possible future second residences or retirement homes. According to Mahmood (cited in Murshid et al., 2002), land is even the most important utilization of overseas remittances. Land constitutes the safest way to invest remittances in Bangladesh, as Siddiqui and Abrar (2001) note. Arable land provides direct economic return through crop production and land can increase in value over time. The use of remittances in releasing mortgaged out land is also quite important in the rural context as it re-establishes the right of the person to cultivate the land. However, most other studies contradict the figures of Mahmood and attach more importance to food and clothing. The study of INSTRAW and IOM (2000) revealed a different expenditure pattern for women migrant labourers to the Middle East. Only 3 per cent of remittances from women migrant labourers were invested in land, and only 2 per cent on home construction and repair. A possible explanation might be that women 
(have to) take up the role of caregivers in the family. Therefore a higher proportion of remittances goes to consumption, health care or education $56 \%$ in INSTRAW and IOM's study). Also Murshid et al.'s (2002) survey showed a different result for the importance of land: only 4 per cent of the remittances was used for this purpose.

A considerable percentage of remittances - between 10 and 19 per cent - is used to repay loans, which primarily fund the migration process (Murshid et al., 2002; INSTRAW and IOM, 2000; Siddiqui and Abrar, 2001). Education receives a small share of remittances, as does health care, 5 per cent in Siddiqui and Abrar's (2001) study and some 4 per cent in Murshid et al.'s (2002) survey. Other expenditures include financing the migration of other family members, social ceremonies such as weddings, funding the hajj, etc.

Investment in business or other ventures by the family is not mentioned very often by the families, and sometimes not at all. Murshid et al. (2002) found proportions of 4 per cent in their study and Siddiqui and Abrar (2001) state 5 per cent. Besides setting up shops, investment can also imply the purchase of a sewing machine to make clothes as in the embroidery project in Sirajgang or the acquisition of stocks in a cooperative project. ${ }^{36}$

A very small proportion of remittances is used by the recipients as savings. Siddiqui and Abrar's (2001) study mentions a percentage of 3 per cent. The survey of INSTRAW and IOM (2000) gave a figure of 7 per cent for women migrant labourers. Other research in Bangladesh has shown that the savings rate of remittance receiving households was higher than that of households that did not receive remittances, in the same income group. The first saved some 50 per cent to 75 per cent of their income, while the latter only 5 per cent (Mahmood, 1991, quoted in Murshid et al., 2002).$^{37}$ This could imply that the remittances - although they themselves are hardly used for savings - open up opportunities for households to save money earned through other income sources. Siddiqui and Abrar (2001) attribute the low proportion of savings to a lack of information about different savings schemes and lack of trust in saving schemes.

To summarize, the available data show that the bulk of remittances is used for consumption purposes. Investment in business or traditional productive uses and in savings is rather small, but remittances are also seen as important financial means for investment in human capital (i.e. education), housing and land purchase. Finally, the importance of the repayment of the cost of migration should not be underestimated. 


\subsubsection{Individual transfers by migrants in order to save or invest in the home country}

Secondly, migrants remit money directly to Bangladesh in order to save or to invest. The government and banks have created a number of bonds and special saving accounts aimed at migrants (see Chapter Five).

Siddiqui and Abrar (2001) showed in their survey that especially the enterprise owners and self-employment Bangladeshi migrant workers have the intention to send money home to invest in productive ventures, while the employed migrant workers are more interested in saving. According to a number of interviewees familiar with the situation in Sylhet ${ }^{38}$ and Ahmad and Zohara (1997), a significant proportion of migrant workers and expatriates who come from Sylhet are interested in investing in the region. Also according to the surveys of Siddiqui (2003) and Kuddus (2003) particularly among expatriate Bangladeshis in the USA and the UK, there is a significant interest to invest in Bangladesh. However, when expatriates or Bangladeshis want to invest they are faced with a number of hindrances. As a result many of them refrain from investing in Bangladesh, or invest in real estate or land. Ahmad and Zohara (1997) identify a number of reasons, which have been listed in Table 4.

TABLE 4

REASONS WHY MIGRANTS AND EXPATRIATES DO NOT INVEST IN PRODUCTIVE VENTURES

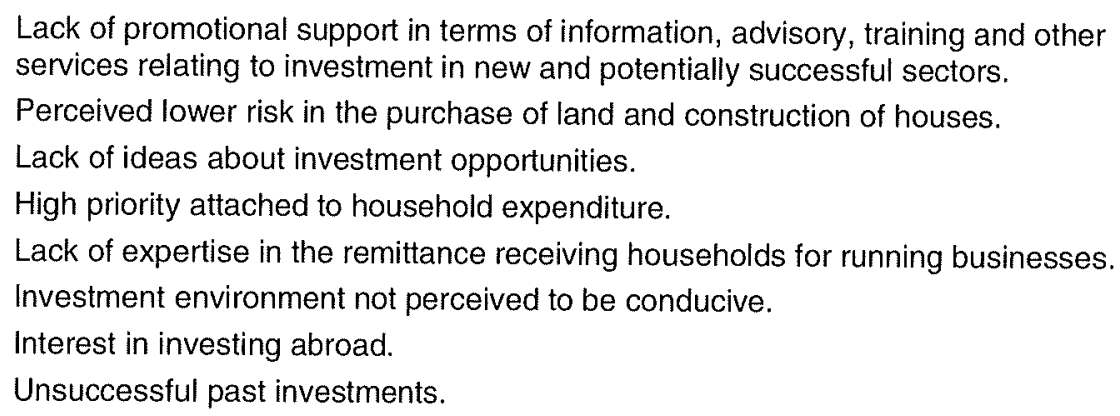

Source: Ahmad and Zohara, 1997: 10.

According to a number of interviewees, such as Prof. Dr Chowdhury of Shajalal University, the expatriate community in London prioritizes investing in their host country. Not only do they think it is more productive to invest in the UK, but they consider the UK as the place where they want to build a future. According to a 
number of studies, migrant workers lack the knowledge to make profitable investments in Bangladesh. Ahmad and Zohora (1997: 9) conclude in their study in Sylhet:

(..) whatever investment made has been largely put to trade, transport and other services which are already crowded by suppliers pushing the profits to very low levels. Of course, the situation may be corrected in the course of time by the dynamics of supply and demand. But, in the process, many may get their finger's burnt.

Siddiqui and Abrar (2001: 62) describe one case:

difficulties in investing remittances in a productive venture when a person is abroad are evident from Jahangir Alam's case. Over three years he sent 570,000 taka. Of that amount 295,000 taka were spent in different business ventures. He invested the bulk of the money in shrimp cultivation and he opened a bookstore in the local market. His brother was looking after these businesses. The shrimp project failed and his brother could not run the bookstore. Currently, the bookstore has been rented out. Following these business failures Alam has kept 180,000 taka in a bank in a joint account on his own and brother's names.

\subsubsection{Individual transfers by migrants to charity or community development}

Interestingly, willingness to invest in community development initiatives seems to be very limited. In the available micro-level studies, there is hardly any evidence of migrant workers who want to make investments in the wider community. This lack of enthusiasm was also evident from the interviews. The main interest lies in investments which benefit the family or the migrant him/herself.

The diaspora may be more willing to invest. A survey of Siddiqui (2004b) among the American and British diaspora pointed out that 31 out of 88 respondents had remitted for community development purposes, 19 for charity, 17 in order to help victims of natural disasters and 61 to pay zakat. ${ }^{39}$ A number of the respondents made yearly contributions to mosques, orphanages or madrasas. The author mentions a business man who had bought land and constructed a hostel for 100 students, a girls' school, and tube wells in every house of his village. Unfortunately, other figures are not available. This type of remittance may be motivated by altruistic reasons, but also by a need to gain political support or esteem and respect in the home village.

\subsubsection{Collective transfers to charity or community development}

A second framework in which remittances are being used for community development exists mainly in the USA and the UK and more specifically in London. 
Expatriate Bangladeshis originating from the same area in Bangladesh and/or living in a same area in the UK have set up a number of trusts and associations. According to Siddiqui (2004b), these associations keep links and serve the village, union ${ }^{40}$ or city where they come from. Via the trust they pool money together and collectively decide on what the money should be used for. According to a number of interviewees, ${ }^{41}$ the money is often given to health care, religious projects such as mosques or educational projects in the villages where the expatriates come from. On the basis of her interviews with expatriates, Siddiqui (2004b) adds to this construction and repair of roads and culverts and the provision of scholarships to students. Also, following natural disasters, these associations organize relief and reconstruction efforts.

Siddiqui (2004b) has listed the Georgia Greater Noakhali Society, Florida Greater Chittagong Society, Habiganj Zila Samity of New York, and Sunamganj District Social Welfare Society in the Bronx as examples in the USA, and Bianibazar Association of London and Baniachang Association of the East End in the UK. Notwithstanding the strong link between Tower Hamlets and the Sylhet, we did not come across any organizations in Sylhet that were explicitly linked to community development with trusts in the UK. Organizations such as the Newham Bengali Community Trust, which has a branch in Sylhet and in London, are working on human rights issues. According to Akther, director of the Sylhet-based organization GJKS, the council of Tower Hamlets in London has assisted some of these trusts. ${ }^{42}$

The initiatives listed by Siddiqui and the trusts to which the interviewees referred seem to be very small scale and not well known by formal institutions in Bangladesh. Furthermore, no formal framework in Bangladesh seems to exist to assist the trusts, associations or villages in Bangladesh in the process. Most interviewees were hardly aware of the existence of the trusts, and have not managed to acquire contact details of people or organizations in Bangladesh who receive money from the trusts. Seemingly, the trusts do not have the same organizational capacity and success as, for instance, the Home Town Associations in Mexico (see Orozco, 2002 ${ }^{43}$ ).

We did not come across trusts or similar associations in the Middle East or in South-East Asian countries. A possible explanation for the lack of this kind of structure might be the limited political rights in these geographical areas. Migrants are not allowed to form associations. A second reason is offered by the short-term nature of the labour migration. Contrary to the migration to the West, migrants only stay for a limited time in the destination country, without bringing over their family and establishing the extensive networks that exist in the UK and the USA. 


\section{IMPACT OF REMITTANCES}

\subsection{Impact of remittances on national economy}

The importance of the remittance flow to the economy of Bangladesh should not be underestimated. All authors agree on this issue. ${ }^{44}$ Table 5 illustrates this for $1997 / 1998$.

\section{TABLE 5}

RELATIONSHIP OF MIGRANT LABOURERS' REMITTANCES TO SELECTED MACROECONOMIC INDICATORS OF BANGLADESH FOR THE FINANCIAL YEAR 1997/1998

\begin{tabular}{|l|c|}
\hline Indicator & $\begin{array}{c}\text { Relationship of migrant labourers' } \\
\text { remittances to indicator (in \%) }\end{array}$ \\
\hline GDP & 4.2 \\
Government revenue & 34.6 \\
Annual development budget & 58.9 \\
Total foreign exchange earnings & 19.1 \\
Imports & 19.0 \\
Foreign aid disbursed & 114.3 \\
Medium- and long-term debt service & 31.0 \\
\hline
\end{tabular}

Source: Afsar et al., 2002: 30.

Remittances contributed more than 4 per cent to the country's GDP and almost 20 per cent of foreign exchange earnings. Remittances amounted to one-third of the total amount of government revenue from taxes and to 30 per cent of the total amount of debt service payments. It equalled 60 per cent of the development budget. The total amount of foreign aid which flows into Bangladesh is less than the total amount of remittances. It should be remembered that these figures only take into account the official remittance flows. ${ }^{45}$

On the other hand, the remittance flow can be unpredictable and is to a certain extent dependent on the political and economic environment of destination countries. The Gulf crisis in the 1990s forced the return of some 56,000 workers back home and led to a sudden decline in remittance inflows from Kuwait and Iraq and also the Asian financial crisis of 1997-98 resulted in a decrease in the demand for labour migrants and a sharp decrease in remittances from that region (Murshid et al., 2002). 


\subsection{Impact of remittances at household and community levels}

Academics are yet to reach an agreement about the impact of remittances on society. Broadening the question to the relationship between migration and remittances on the one hand, and development on the other hand, two extreme viewpoints can be distinguished (Taylor, 1999). The followers of the developmentalist viewpoint argue that:

(1) migration decisions are part of family strategies to raise income, obtain funds to invest in new activities, and insure against income and production risks; and (2) remittances, or in some case simply the potential for remittances, consequently set in motion a development dynamic by loosening production and investment constraints faced by households in poor developing environments (ibid, p. 64).

The "migrant syndrome" theory implies on the other hand that:

Lucrative migration activities drain migrant sending areas of their labour and capital, crowding out local production of tradable goods. Because migration is a self-perpetuating process, over time, villages, regions, and in a few cases even countries, come to specialize in migration (i.e. the export of labour), serving as nurseries and nursing homes for their largely migrant workforces (ibid, p. 64).

Unfortunately, studies on the impact of remittances at the wider community level in Bangladesh are quasi non-existent. However, the studies on the utilization of remittances do shed some light on the impact of remittances at the household level.

TABLE 6

IMPACT OF REMITTANCES

AT THE COMMUNITY AND HOUSEHOLD LEVELS IN BANGLADESH

\begin{tabular}{|l|l|}
\hline Positive impact of remittances & \multicolumn{1}{|c|}{ Negative impact } \\
\hline $\begin{array}{l}\text { Allowing families to meet basic needs } \\
\text { Opening up of opportunities for investing } \\
\text { in children's education, health care, etc. } \\
\text { Loosening of constraints in family budget } \\
\text { to invest in business or savings }\end{array}$ & $\begin{array}{l}\text { Dependency on remittances } \\
\text { Neglect of local productive activities by } \\
\text { famergency resources } \\
\text { Social security for the elderly } \\
\text { Boost of local economy } \\
\text { Effect on inequality levels? }\end{array}$ \\
\hline
\end{tabular}


Worth mentioning here is the study of Afsar et al. (2002). They have carried out a cost-benefit analysis among migrant workers in the UAE. On the basis of direct benefits of remittances and costs of migration the authors concluded that migration had yielded a benefit-cost ratio of 2.88. In Table 6 positive and negative aspects of remittances at the household and community levels are listed. Comparison with international studies indicate that this list is not unique for Bangladesh (see, for instance, Penent, 2003 and Russell, 1986).

\subsubsection{Additional income source, improved living conditions and investment}

Remittances constitute an important extra income source for migrant families. In many cases this extra income allows families to meet their basic needs. It also opens up opportunities to invest in the family's well-being, such as sending children to school, or improving the family's health status and living conditions. As Mr Mustafa of BAIRA stated in an interview, "Remittances have been causing a silent economic revolution in Bangladesh". Kuhn and Menken (2002) found evidence in Matlab that without remittances, children's access to education would have been severely hindered. The additional income also loosens constraints to invest in business or to save. In the Pankowri fisheries project (see Chapter Five), an interesting interplay between money received from fish and rice cultivation and remittances could be identified. In this case remittances allowed the expansion of the fisheries project, while the income from the fisheries project funded the migration process.

\subsubsection{Emergency resources}

Dr Rahman of the PPRC ${ }^{46}$ states that remittances function as emergency resources. Often, poor families have limited savings and therefore limited access to emergency resources. When money is needed at short notice - to buy land, to send someone abroad, or in case of illness - remittances can provide the resources. Kuhn and Menken (2002) and Gardner (1995) found evidence that remittances have saved families in Matlab from entering a vulnerable period of debt.

\subsubsection{Social security for the elderly}

According to Kuhn (2001), remittances form a major source of money for parental support and, as such, they act as a kind of social security resource base for the elderly in Bangladesh. The author warns that this system is coming under threat due to decreasing fertility rates, higher life expectancy and slow economic growth in 
Bangladesh. On the one hand the next generation of elderly will have fewer children to support them. On the other hand, they will live longer and thus the children will be supporting their parents for a longer period than before. The diaspora in particular will be faced with a dilemma: the responsibility towards the parents may hinder them from investing in their own children, family and business in the destination country. Interestingly, this situation resembles the social security problems confronting the aging European and Japanese societies.

\subsubsection{Boost local economy}

Taylor (1999) argues that an increased consumption demand can result in higher investments by other households or firms to fulfil this demand. In a forthcoming study of the PPRC on the meso-economy, which covers 188 unions and market centres all over Bangladesh, the researchers conclude that remittances indeed have resulted in a demand boost for certain products at the local level. As a consequence, certain economic activities which cater for these products flourish. Unfortunately, no detailed figures are available at this point in time. ${ }^{47}$ An interesting side effect of the wealth generated through remittances is the attraction of migrants from other regions into the economically successful area. According to Dr Chowdhury of Shajalal University, ${ }^{48}$ this has happened and is still going on in the district of Sylhet. Migrants from neighbouring and poorer regions are moving to the district in search of employment in economic sectors that have seen an economic boost due to remittances.

\subsubsection{Effect on levels of inequality?}

The debate about the impact of remittances on degrees of inequality in Bangladesh is still ongoing.

On the one hand, the above mentioned positive aspects of remittances can result in more equitable income distribution among the population. Tangible figures to support this argument are not available, but indications that without remittances many families would have problems meeting their basic needs point in this direction.

On the other hand, poor families who do not have the money to send members abroad do not have access to remittances. Thus the gap could increase between the slightly better-off families and the ultra poor. Chowdhury's (1992 and 1995) research in a village in Sylhet revealed that the inflow of remittances had significantly widened the socio-economic differences between remittance receiving and nonreceiving families. 
In short, there is no conclusive evidence on the impact of remittances on inequality in Bangladesh.

\subsubsection{Dependency on remittances}

Households can become very dependent on the inflow of remittances. The already mentioned study of Siddiqui and Abrar (2001) revealed that 51 per cent of the total earnings of families in the study sample was derived from remittances. Mahmood (cited in Murshid et al., 2002) found that remittances of the Bangladeshi migrants living in Japan accounted for 70 per cent of household income on average. Ahmad and Zohara (1997) derived a similar percentage from their study in Sylhet. This dependency can cause problems when the political or economic situation in the destination countries alter - for instance putting a stop to migration - depriving the migrants and their families of their income. When labour migration is approached with a diversification strategy this threat is less prominent.

\subsubsection{Neglect of local productive activities?}

In the literature and in the interviews, no evidence was found of the so-called migrant syndrome (see above) in Bangladesh. However, due to the limited amount of research available, it is too soon to conclude that this does not exist in certain areas of Bangladesh. Ahmad and Zohara (1997) note that in their study sample the other 30 per cent of household income was derived from agriculture and businesses. For rural households without any migrant workers abroad, these sectors usually provide the main sources of income. As the authors suggest, it would be useful to find out whether agriculture has been neglected by the remittance receiving families given that remittances are an easier source of income or whether the neglect of agriculture is due to the fact that remittance receivers have diversified their livelihoods through investments.

\subsubsection{Inflation}

Superficial signs of inflation due to remittances can be seen in Sylhet. De Haan (1999) cites Mahmud and Osman (1980), indicating that remittances in Bangladesh led to rising inequality and impoverishment. Research of Islam, (also cited by De Haan, 1999) found that remittances from the Middle East to Chittagong are used to buy social status and to purchase land, leading to a concentration of landownership, and a sudden increase in the price of land. 


\subsubsection{Impact of migration}

As mentioned earlier, remittances are intrinsically linked with migration. Therefore, the positive and negative impacts of migration should be taken into account when talking about the consequences of remittances. The question should be asked whether the benefits of remittances outweigh the economic and social costs of migration. Earlier we argued that labour migrants are confronted with a number of problems during the migration process, in the destination countries and upon return. In addition, the migrant's family in Bangladesh may experience problems. Merely the fact that one of the family members is abroad for a relatively long period of time may give rise to considerable emotional strain ${ }^{49}$ and disruption of social norms (see, for instance, Mahmood, 1992). 


\section{INITIATIVES AND POLICIES AIMED AT HARNESSING THE BENEFITS OF REMITTANCES}

The initiatives and policies taken by governmental and other bodies involving remittances can be distinguished according to their aim:

- Encouraging labour migration to increase the level of remittances;

- Encouraging formalized methods of remitting;

- Tapping into non-resident remittances by facilitating investment;

- Influencing the utilization of remittances.

\subsection{Encouraging labour migration to increase the level of remittances}

In Chapter Four, it was argued that remittances are very important for the Bangladeshi national economy. In addition, labour migration is seen as a strategy to combat unemployment in Bangladesh. For these reasons Bangladesh is encouraging labour migration. BOESL and BMET are promoting Bangladeshi labour in other countries and the Bangladeshi government is looking for avenues to set up bilateral agreements with foreign countries. In Chapter Three, we elaborated on the dynamics of labour migration in Bangladesh and related policies. Unfortunately, as mentioned earlier, the efforts taken to promote labour migration are not matched by the efforts to protect the rights of migrants in the destination country or in the migration process. In general, there is no comprehensive migration management policy that looks at all forms of migration in a systematic and coordinated manner.

\subsection{Targeting remittance channel to formalize method of remittance}

The main measures taken by the $\mathrm{BB}$ and commercial banks targeting remittances in recent years are aimed at encouraging and facilitating the use of official channels for transferring money.

\subsubsection{Providing access to banking facilities}

One way of doing this entails providing facilities for migrants to use official channels and to enable families to collect the remitted money nearby. The establishment of new exchange houses and branches of Bangladeshi banks abroad is one initiative 
in this context. Furthermore, the BB is encouraging the commercial banks to link up with foreign banks and exchange houses and set up taka drawing arrangements ${ }^{50}$ (Murshid et al., 2002). However, the limited availability of branches of banks in rural areas of Bangladesh remains a problem. In this context the recent entry of BRAC Bank in the remittance field, as well as the interest shown by the Grameen Bank in remittance channelling could offer solutions. The NGOs, BRAC and Grameen Bank have an extensive network of over 1,200 micro-finance institution offices in the rural areas of Bangladesh. At the moment they deal with less than 1 per cent of total officially remitted money. ${ }^{51}$ BRAC Bank has been using these branches to disseminate the money drafts to recipients. Grameen Bank, however, does not have permission to deal with foreign exchange, but is planning to cooperate with foreign banks. These banks could arrange the remittance of the money, while Grameen Bank would be responsible for distribution to the rural areas ${ }^{52}$ (Siddiqui and Abrar, 2001). The interest and involvement of MFIs in channelling remittances is a necessary step to explore alternative methods of remittance transfer. This expansion of options could address the existing gaps in accessing banking facilities for migrants.

\subsubsection{Reforming official remittance channels}

Efforts have been taken to reform the official channels and adapt them to the needs of the migrants and their families. Among the most important measures are the following (Kuddus, 2003, and Embassy of Bangladesh):

- Reduction of transaction time

- Reduction of transaction costs (by cutting commission fees)

- Making remittances tax free

- Simplifying formalities

- Regular monitoring to ensure service

- Maintaining where possible the same exchange rate as the informal market

- Penalizing unauthorized remittance dealers

The recent steps are to ensure that the formal methods of transferring funds take on some of the characteristics of the informal channels to reduce the comparative advantage of the hundi system. According to representatives of Bangladesh Bank and other financial bodies, ${ }^{53}$ the initiatives taken to encourage the use of official channels to remit money have been successful. Still, improvement is necessary in order to compete effectively with the hundi system. Siddiqui and Abrar (2001) refer to testimonies of migrants who complain that bank services are not adapted to the needs of migrant workers. For instance, many migrant workers do not have the opportunity to visit banks during the official opening hours. 


\subsubsection{Creating special accounts}

BB has created a number of schemes, specifically tailored to investors and nonresidents. These include the Non-resident Taka Account (NITA), the Non-resident Foreign Currency Deposit (NFCD) Account and the Resident Foreign Currency Deposit (RFCD) Account. These accounts offer several financial advantages for the account holders. For instance, the NFCD account can be opened for different periods of time, in different currencies and the interest accrued is tax free. The NITA, on the other hand is specifically aimed at investment in Bangladesh (see Kuddus, 2003, and Siddiqui and Abrar, 2001).

\subsubsection{Raising awareness}

One of the main problems is the limited awareness of migrant workers about these schemes and official channels, and about using banking facilities in general. Different institutions try to create awareness among migrant workers to remit their money through official channels. BMET and BAIRA include this in their pre-departure orientation training. The NGO SHISUK and the migrant associations BOMSA and WARBE also devote attention to this. ${ }^{54}$ BOMSA, for instance, advises women migrants to set up an account in their own name to avoid the husband or family taking control of the money, so that everything is expended when the woman returns. ${ }^{55}$ SHISUK has a programme in Sirajgang (see also $\$ 4$ in this chapter). They discuss problems of people working abroad - including issues involving remittances with would-be female migrants as well as spouses of migrant workers. Some banks are also actively involved in encouraging migrant workers to use official channels. Officials of IBBL for instance travel to Saudi Arabia to inform the migrants about the services provided by the bank (Siddiqui and Abrar, 2001).

\subsection{Tapping into non-resident remittances by facilitating investment}

A number of actions and policies are aimed at attracting investment by nonresidents.

\subsubsection{Launching bonds}

Bangladesh Bank has launched various bonds to attract foreign exchange from migrants and expatriates. The oldest one is the Wage Earner Development Bond, created in 1986. A migrant can buy a bond at Bangladeshi banks and embassies abroad. It is available in different denominations, ranging from 1,000 taka to 
50,000 taka, for specific time periods, and offers high interest rates. Relatively new are the US Dollar Premium Bond and the US Dollar Investment Bond. These are sold by commercial banks and the interest rates can be paid in dollars. Dominations of these bonds range from US\$500 to US\$50,000.

\subsubsection{Tax benefits}

Bangladesh Bank offers tax benefits for expatriates. For instance, interest on the NFCD account is now tax free, as is the purchase of the Wage Earners Development Bond. Furthermore, a tax identification number is not required for buying immovable property in Bangladesh. Exchange regulations have also been relaxed. All transactions can be made through an authorized dealer without the permission of Bangladesh Bank. In addition, the government gives awards to non-resident Bangladeshis who have made valuable contributions to the Bangladesh economy and society. The Government is planning to give special benefits to those termed as INRB (Important Non-Resident Bangladeshis) as well. These are incentives given to Bangladeshis living abroad who have contributed in some way to the Bangladeshi economy (Kuddus, 2003 ${ }^{56}$.

\subsubsection{Promoting investment in Bangladesh and offering assistance}

Initiatives are also taken by the private sector to encourage investment in Bangladesh. These initiatives are particularly apparent in Sylhet due to the strong link with the expatriate community. One example is the Investors Forum Sylhet Bangladesh (IFSB), established in 1995 by a group of business people. They organize seminars in Sylhet and in the UK and offer assistance and information to people who want to invest in Sylhet. Other examples are the British-Bangladesh Chamber of Commerce which also tries to strengthen investors' ties between the UK and Sylhet ${ }^{57}$ and - from the NGO sector - Grameen Jonokallyan Sangsad (GJKS). However, the success of most of these initiatives remains limited, as Mr Chowdhury of IFSB and Ms Akther of GJKS admit. ${ }^{58}$ The main reasons why migrants and expatriates are reluctant to invest in Bangladesh have already been listed in $\$ 3.2$ of Chapter Three (see for instance Table 4).

\subsection{Influencing the utilization of remittances}

While many measures have been taken to influence the choice of the remittance method, less attention has been given to the use of remittances. It has been very difficult to find initiatives specifically aimed at the utilization of remittances. Of course, receivers invest remittances in certain areas, but we have found hardly any 
tailored schemes for remittance investments in Bangladesh. In the following paragraphs we will give the few examples we have encountered. The next chapter will deal with the reasons why remittances are not used for productive purposes in a less haphazard way.

\subsubsection{Saving and investment schemes of banks}

The main initiatives of banks and the government do not go beyond the already mentioned bonds and accounts. A number of banks, for instance IBBL and National Bank, have saving, investment and insurance schemes that are not specifically developed for migrant workers but can be accessed by them.

\subsubsection{Offering opportunities for investment of remittances}

Besides these schemes, the migrant associations WARBE, BOMSA and the NGO SHISUK offer advice and assistance to returned migrant workers in the reintegration process. They also work with the migrant workers' families in order to raise awareness about the situation of the migrant. In this way they urge them to save some of the remitted money. Two projects of SHISUK indirectly influence the use of remittances. Under these projects, a portion of the income of family members of migrant workers (which is partly derived from remittances) is invested in a community development project.

The first is the Pankowri Fisheries Project at Elliotgonj in Daudkandi Upazila of Comilla District. Although the project is not specifically aimed at migrants or remittances, it has some significant implications for the use of remittances (see Box 1).

The second project is set in Sirajgang and is directly aimed at spouses of migrants. This project started in 2000 and involves 180 spouses of migrant workers. SHISUK has organized them into 18 groups in seven different villages. Helped with a starting capital from CARAM (Coordination of Action on Aids and Mobility) Asia, SHISUK has bought a number of sewing machines and trains the women as garment workers. The NGO encourages the women, most of whom are wives and family members of migrant workers, to save money and with the savings a similar structure of shareholding will be set up to that in Elliotgonj. The income of the women is partly derived from remittances of their husbands. 
OFFERING REMITTANCE INVESTMENT STRUCTURES: THE PANKOWRI FISHERIES PROJECT IN ELLIOTGONJ

The Pankowri Fisheries Project in Elliotgonj, a village in Daudkandi upazila of the district of Comilla, is not specifically aimed at migrants but was initiated to provide the population of an area with high propensity to migrate with a livelihood option that could provide avenues for remittance investment. According to interviews with inhabitants of Elliotgonj, a significant number of families have family members who work as wage labourers abroad. Exact figures, however, were not available. Until the 1990s the main economic activity in Elliotgonj consisted of rice cultivation. However, floods, accumulation of water and slow drainage inhibited the productivity and damaged the crops. In the mid-1990s one person started with the cultivation of fish during the rainy season. A few years later, the NGO SHISUK initiated a pilot project in the area to develop a community fisheries programme. The project covered 115 hectares of flood plain surrounded by six villages. Land and a starting capital were needed. In a first stage SHISUK organized 500 landowning households to participate in the project. In addition the households raised 83 per cent of the total capital of 2 million taka through buying shares. SHISUK contributed 17 per cent by buying 7 per cent of the remaining shares. The face value of each share was 1,000 taka, while one person could buy a maximum of 20 shares. In the project area, fish was cultivated for seven months during the rainy season, and rice during the other months. As the evaluation of the Centre on Integrated Rural Development for Asia and the Pacific (see CIRDAP, 2002) showed, the project turned out to be an economic success. In a second stage landless households were also involved in buying shares. According to a survey with 70 of the 500 households by CIRDAP (2002) on average 19 per cent of the total income of these households was derived from the fisheries projects, 21 per cent from wage labour and 19 per cent from remittances from abroad. From interviews with fathers of migrants, returnee migrants and spouses of migrants, a complex picture of the interaction between remittances and investment and earnings of the fisheries project becomes apparent. Some of interviewed inhabitants told us that they initially financed the migration of family members by selling land. Now, migration is financed in some cases by the return from the fisheries project. Remittances contribute significantly to the total income and thus financed indirectly the buying of shares. One returned migrant told us that upon return he could buy a number of shares with the money he had saved during his time as a migrant labourer. 


\section{HINDRANCES, OPPORTUNITIES AND POSSIBLE AVENUES FOR ENHANCING THE IMPACT OF REMITTANCES ON THE BROADER SOCIETY}

\subsection{Hindrances and opportunities for enhancing the impact of remittances on the broader society}

Until now we have analysed the dynamics behind the current migration and remittance patterns in Bangladesh. The labour migrants, the higher and the lower income diaspora constitute three distinct sources of remittances for Bangladesh. We have described the history as well as the characteristics and the situation in which they currently work and live. Furthermore, we have seen that remittances can be of four different types, depending on the remitter and the purpose of the transfer. Notwithstanding the indirect effects of remittances on the community, we can conclude that remittances are seldom mobilized directly for productive purposes that have an impact on the broader society. The existing initiatives about remittances mainly target the channelling of remittances, while the mentioned initiatives about the utilization of remittances remain very limited in scope.

A number of reasons for this can be identified. In $\$ 3.2$ of Chapter Three we listed the hindrances for migrants to invest in Bangladesh. Broadening the scope of the utilization of remittances by migrants and their families for productive purposes that benefit the wider community, we conclude that the hindrances differ according to the three main migrant types we identified in Chapter Two. We must emphasize that the classification of migrants is somewhat arbitrary, and that the boundaries between the three groups are not rigid in reality. Table 7 shows the hindrances and opportunities for using remittances for productive purposes that have an impact on the broader community.

For many labour migrants and their families the proportion that could be mobilized for productive purposes or community development is - although important very low and the amount it represents is too small. This is mainly due to high migration costs, low wages and the exploited situation of labour migrants in the destination country, as well as the prioritization of other uses for remittances. However with large numbers of labour migrants, the cumulative amount that could be invested is significant. Also, family pressure and ignorance about the migrant's situation in the destination country play an important role. In addition, the human rights situation of labour migrants as well as participation in the political arena is cumbersome. 


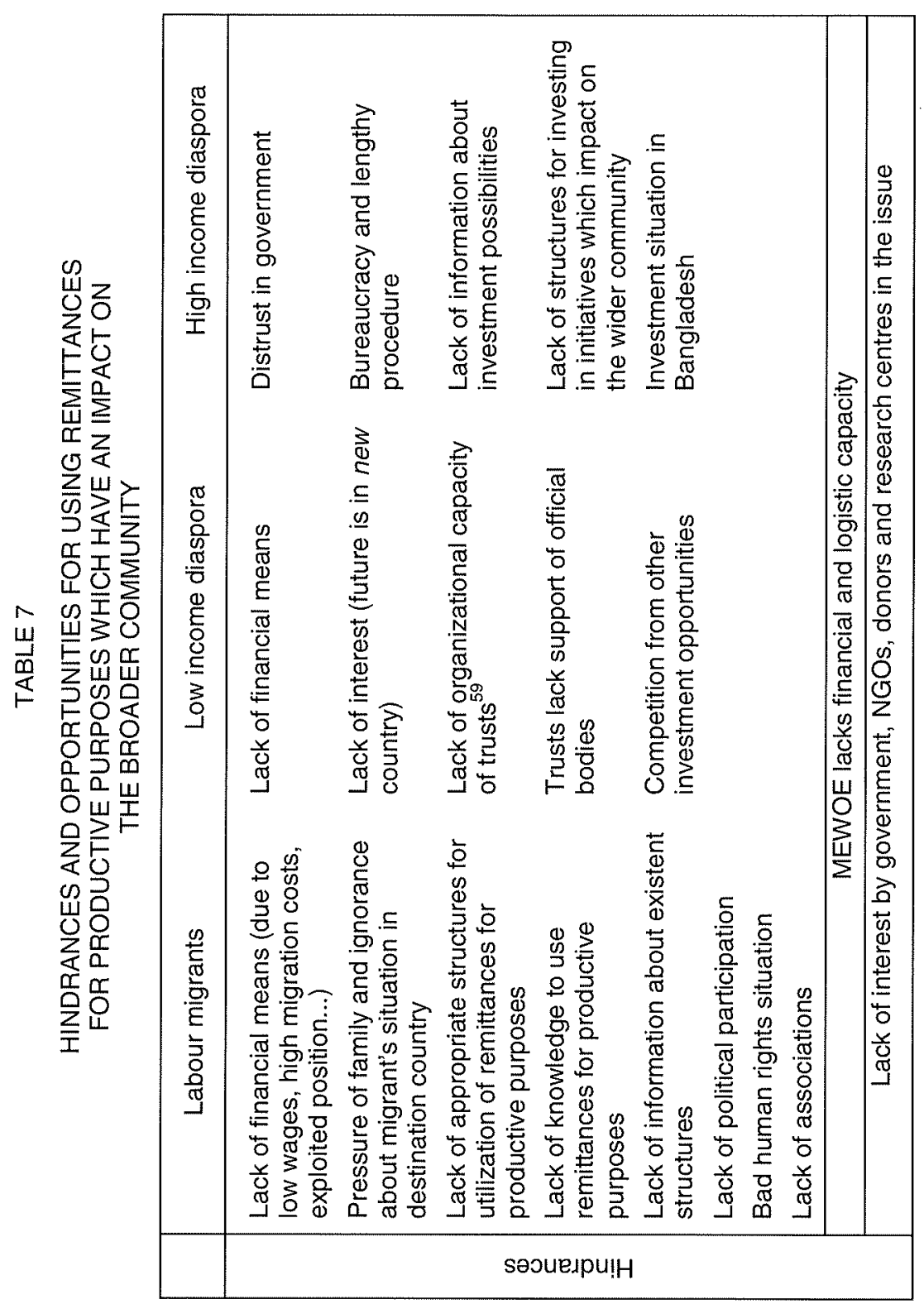




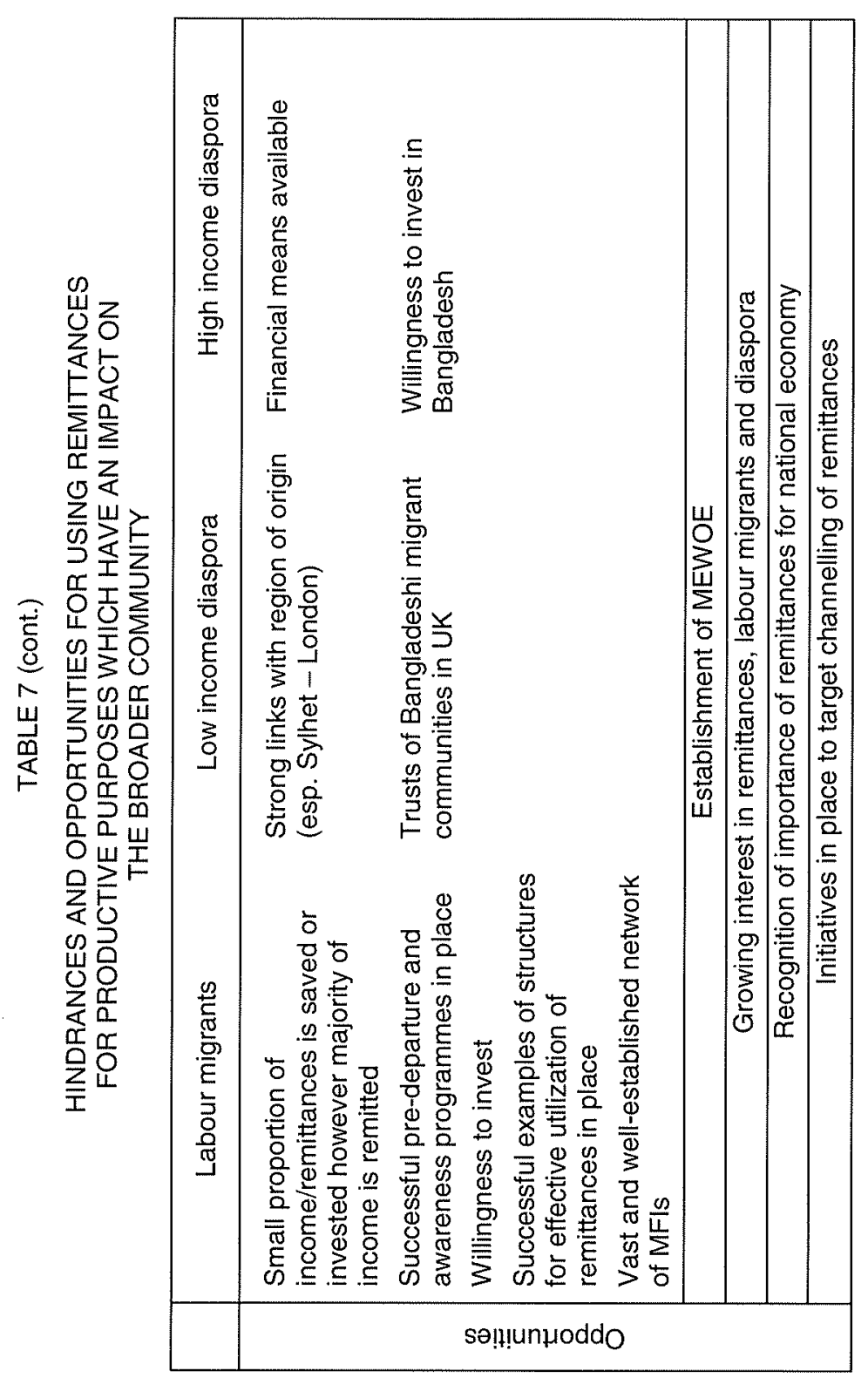


Furthermore, there are only a few structures in place to assist migrants in using money for productive purposes. Some returned migrants interviewed ${ }^{60}$ expressed their wish for a specific migrant bank better adapted to their needs.

There is scope for utilizing remittances more effectively. Not all labour migrants have small earnings, and even the low-income migrant workers save or try to invest a very small proportion of their earnings. Where an appropriate structure is available, labour migrants have a willingness to invest in productive and/or community development ventures. SHISUK and other countries have shown that structures can be created to assist the migrants. Bangladesh has an extensive network of MFIs that cater for the poor households (see \$2.2). In addition, migrant associations, NGOs and even BMET are offering pre-departure orientation programmes that raise awareness about remittance utilization.

The lower income diaspora is not interested in investing in Bangladesh, because they want to build a future for their children in the new country. Furthermore, they do not have the financial means to make big investments in Bangladesh. The migrant associations have not been supported by the Bangladeshi government, and seem to lack the organizational capacity of the Home Town Associations in Mexico. ${ }^{61}$

Despite the strong links of the low-income diaspora with the region of origin, particularly in Sylhet, there is little evidence of migrants pooling money together to invest in community initiatives.

The higher income diaspora has the financial means and shows a willingness to invest in Bangladesh, but a distrust in the government, bureaucracy and a lack of information about investment possibilities as well as appropriate structures hinder their involvement.

In addition, only a few research centres, donors and NGOs pay attention to the diaspora and labour migrants. Just recently, more attention has been given to the issue of remittances. The establishment of the Ministry aimed at migrants (MEWOE) is proof of the government's interest in migration issues. Akbory (2003) argues, however, that the ministry lacks the financial, logistic and technical capacity to deal adequately with the issue. 


\subsection{Possible avenues to enhance the impact of remittances on the broader society}

What could be done to mobilize remittances for community development and productive purposes that have an impact at the broader community level? Most importantly the human rights situation and the needs of labour migrants should be addressed, as well as the economic environment of Bangladesh. However, these issues lie beyond the scope of this report. In the following paragraphs we will focus on how structures could be set up to channel remittances into initiatives and at the same time emphasis is placed on raising awareness among migrants to utilize the remittances in a way that is beneficial to both themselves and the community. Other or similar recommendations have been made by other authors in Bangladesh. In addition, an increasing number of international research institutions and (inter)governmental agencies are looking at possible avenues to increase the development potential of remittances with suggestions that could be explored in the Bangladesh context. A non-exhaustive list of studies (Bangladeshi as well as international) has been provided in Annex E.

\subsubsection{Pre-departure orientation and awareness-raising programme}

An extended pre-departure orientation programme, combined with awarenessraising initiatives for both migrants and their families, and information dissemination in the destination countries could address the problem of limited awareness about the costs and benefits of the migration process, as well as the possible remittance channelling methods and utilization.

The official pre-departure orientation programme of two hours organized by BMET is too short to provide adequate information about these issues. Furthermore, labour migrants' families are not included in the awareness-raising programme. In 2001, Siddiqui developed a proposal for the Ministry of Labour for the streamlining of recruitment procedures and the protection of rights and interests of migrant workers (see Siddiqui, 2002b). The suggestions are based on the structure that is already in place in the Philippines and Sri Lanka. The author suggests that specialized agencies, such as NGOs and migrant support groups, should conduct the pre-departure orientation. The information could consist of mainstreaming remitting opportunities, related costs, timeframes, financial products (including saving and investment options) and reliability. ${ }^{62}$ The extensive network of BMET's pre-departure orientation facilities could be used. Instead of implementing the orientation programme, BMET should rather monitor the process and check whether the migrant has gone through a pre-departure orientation programme before leaving. Siddiqui (2002b) suggests that this orientation programme is part of a wider pre-departure orientation 
programme (concerning the whole migration and settlement process) of one or two weeks (Siddiqui, 2002b). Besides this classroom type education, brochures and leaflets about the remittance utilization and transfer methods should be produced and distributed.$^{63}$ Similar information campaigns can be set up for the diaspora as well.

In the destination country, periodic meetings should be organized by the Bangladeshi mission and information should be disseminated through different media by the Government of Bangladesh. International donors could be approached in order to provide financial support particularly for awareness-raising programmes. ${ }^{64}$ An example of the pre-departure training programme is given by SHISUK. Their project in Sirajgang also includes raising awareness among families of migrant workers about the situation migrants face in the destination countries. Furthermore, returnee migrants play an important role in this process. They share their experiences with future migrants and their families. ${ }^{65}$

Although the existing migrant associations are still very small and lack the organizational skills to carry out an extensive nationwide pre-departure orientation programme, they possess the knowledge about the problems which migrant labourers face. Financial orientation could be integrated into the existing pre-departure programmes offered by such agencies.

It is also important to utilize the valuable expertise of international organizations working in the field of migration (such as IOM) in designing the programmes and facilitating collaborations between government initiatives and NGO efforts.

\subsubsection{Linking MFIs to remittances ${ }^{66}$}

Bangladesh is renowned for its pioneering role in micro finance and micro credit systems (see Wood and Sharif, 1997). They have developed specific loan and savings programmes for poor - especially, but not exclusively - female Bangladeshis. Their operation is characterized by a social component, i.e. empowerment and poverty alleviation. Each of the four big MFIs (i.e. BRAC, Grameen, ASA and Proshika) has between 2 and 4 million members and they reach between 20,000 and 65,000 villages. ${ }^{67}$ Their vast network enables them to reach the remote rural areas. Only recently have MFIs or the NGOs linked to the MFIs shown some interest in working on remittances. For instance BRAC Bank is concentrating on the channelling of remittances and Grameen Bank will do this - although indirectly - in the future. ${ }^{68}$ However, channelling of remittances is the only issue MFIs are concentrating on at the moment and the utilization or the development of savings programmes in which remittances are tapped is not an issue of concern for them. Nevertheless, many women who are involved in the savings schemes have husbands or other family members 
abroad working as migrant labourers. In addition, loans from the MFIs are sometimes used to fund the migration process. ${ }^{69}$

At the moment there are a number of bottlenecks for the mobilization of remittances in the savings schemes of the MFIs. Legally, MFIs are not allowed to make financial transactions. As Siddiqui and Abrar (2001) point out, strictly speaking MFIs are not even allowed to run their own credit programmes. However, the overwhelming success and their contribution to alleviating socio-economic problems have led the government to let them continue. Nevertheless, a further extension of their activities in other financial realms would probably not be welcomed by the government. Furthermore, MFIs can only mobilize savings of their members. Migrant workers and their families have first to become members before they can make use of the savings services of the MFIs. The activities of MFIs are already relatively extensive. Thus, involvement in yet another activity discourages some MFIs. Not surprisingly, from our interviews with MFIs or NGOs linked to MFIs we have learned that they do not seem too keen to involve themselves in the utilization of remittances. ${ }^{70}$

Examples from other countries have shown, however, that the involvement of MFIs in remittance mobilization and utilization can be successful. For instance the Multilateral Investment Fund (MIF) of the Inter-American Development Bank (IADB) has assisted a number of MFIs in several Latin American countries. Also in Latin America, the World Council of Credit Unions (WOCCU) is carrying out the International Remittance Network programme. A successful example in the Philippines is provided by UNLAD-KABAYAN and in Mali by the Centre International de Développement et de Recherche and the Caisse Villageoise d'Epargne et de Crédit Autogéreés $^{71}$ (ILO, 2000; Penent, 2003; CARANA Corporation, 2004).

Savings and credit schemes of MFIs would be appropriate for low-income labour migrants as well as the diaspora. However for the high-income diaspora development bonds seem more suitable. At the moment the existing bonds are already aimed at the high-income migrant community. There are hardly any structures available to invest in ventures specifically aimed at providing benefits for the wider community.

NGOs might wish to introduce credit programmes aimed at providing the migrants and their families with incentives to invest their money in various initiatives. Incentives could consist of small loans to migrant communities with communities required to invest a sum equal to the requested loan. This "matching fund" will give migrant households the possibility of putting their remittances to work. However, these programmes should recognize that migrants are not necessarily entrepreneurs and counselling on business management should also be a part of the programme. 
Linking MFIs to remittance management in Bangladesh also holds other benefits. Most of the MFIs use group collateral and therefore have formed groups of creditors all over the country. These groups could provide important structures to enhance the benefits of migration in general and remittances in particular. They could replicate to a certain extent the home town associations. However, implementing such programmes requires international cooperation between the locally operating NGOs and migrants workers abroad. 


\section{CONCLUSION}

Although remittances and migration in Bangladesh have received an increasing amount of attention in recent years, it is still not adequate to determine unambiguously the impact of remittances on the broader society. Because most studies only cover small areas and numbers of migrants or recipients of transfer, it is very difficult to extrapolate the conclusions of these studies. In addition, a comparison between the findings shows that the utilization of remittances and the impact on the broader society is very context-specific.

Based on the remittance dynamics, the migrant communities can be divided into three groups: temporary migrant labourers, high-income diaspora and low-income diaspora. This categorization is not rigid but serves as an analytical tool. As we argued in Chapter Two, these three communities differ in emigration history, in socioeconomic characteristics, and in living and working conditions. In Bangladesh, four different types of transfers exist, of which remittances sent to family members is the most important.

We have found that remittances can have negative as well as positive impacts on the community (see Chapter Four). Remittances are very important for the receiving families to meet their basic needs and as an additional income source. However, we could not find conclusive evidence concerning the impact of remittance flows on income distribution. In addition, the cost of migration can be very considerable and endanger the positive economic impact on the sender and receiver of remittances.

Clearly, more research is needed on the following topics:

- The impact of remittances on the receivers and the senders, as well as on the broader community;

- The gender aspect of migration and remittances;

- The role of the diaspora, including collective remittances, also important in other migrant communities, such as the Mexicans in the US and West Africans in France;

- The use of remittances as a development tool in Bangladesh.

The policies and initiatives implemented to enhance the impact of remittances are mainly aimed at encouraging the sending of financial transfers through official channels, while the utilization of remittances is neglected by official bodies.

When proposing new measures, it must be kept in mind that remittances are private money flows. Therefore, the government should focus on enabling migrants to 
send and use their remittances in the most effective ways, according to their own needs. In Chapter Six we identified a variety of hindrances and opportunities for the three migrant communities to enhance the impact of remittances on the broader society.

In a number of countries, governments, NGOs, financial institutions and research institutes are exploring new ways of addressing remittance senders and receivers' needs in terms of remittance methods and utilization. These initiatives (i.e. research and pilot programmes) are certainly worth studying in more detail and could assist the Bangladesh Government in its search for effective measures. In this report we have singled out pre-departure orientation programmes and incorporating MFIs in remittances.

Pre-departure training for labour migrants is not only important to reduce the human and economic costs of migration; it can also be a powerful tool in raising awareness about remittance methods and utilization. The involvement of a variety of actors (international institutions, migrant associations, NGOs and governmental bodies) is instrumental in the success of these initiatives.

Considering the extensive network of MFIs in Bangladesh and the fact that Bangladesh is one of the pioneers in issues involving micro-finance and micro-credit schemes on the one hand, and the successful implementation of linking MFIs to remittances in other countries on the other hand, MFIs' involvement in remittances in Bangladesh could be one of the most promising avenues for optimizing the development impact of remittances. MFIs can as well function as distribution agents in remote areas (which they already do), as administer schemes which support the use of remittances for savings and investments for development. In this regard, the possibility of matching fund schemes should be explored.

A last, but important remark refers to social and human rights conditions of migrants. Although the focus of this paper has been the very economic issue of remittances, the second chapter has made clear that the success of policies enhancing the development potential of remittances is inextricably linked to improving the social and human rights conditions of (especially labour) migrants during the migration process (before, during and after migrating). 
ANNEX A

MICRO-LEVEL STUDIES ON MIGRANTS (AND REMITTANCES) IN BANGLADESH ${ }^{72}$

\begin{tabular}{|l|l|}
\hline Reference & \multicolumn{1}{|c|}{ Description } \\
\hline Abdul-Aziz (2001) & $\begin{array}{l}\text { Survey among 141 Bangladeshi migrant construction } \\
\text { workers in Penang, Klang Valley and Johor Bahru, } \\
\text { Malaysia in 1996-1997. }\end{array}$ \\
\hline Afsar (1999a and b) & $\begin{array}{l}\text { Survey among 600 migrant and non-migrant } \\
\text { households in four wards of Dhaka City (i.e. Lalbagh, } \\
\text { Jurain, Purana Paltan and Mirpur), supplemented by } \\
\text { case studies of stayers, returned and "failed" migrant } \\
\text { families of temporary migrants. The study mainly deals } \\
\text { with internal rural-urban migrants. }\end{array}$ \\
\hline Afsar et al. (2002) & $\begin{array}{l}\text { Survey among 85 migrant workers in the UAE, along } \\
\text { with 15 employers; 105 migrant households from three } \\
\text { thanas (Fatikchari, Keraniganj and Chatkhil). }\end{array}$ \\
\hline $\begin{array}{l}\text { Ahmad and Zohora } \\
\text { (1997) }\end{array}$ & $\begin{array}{l}\text { Survey among 100 migrant households and three } \\
\text { participatory rapid appraisals involving 55 participants in } \\
\text { Sylhet Division. }\end{array}$ \\
\hline $\begin{array}{l}\text { Chowdhury (1992 and } \\
1995)\end{array}$ & $\begin{array}{l}\text { Survey among 70 remittance receiving and 30 non- } \\
\text { receiving households in a village of Matiura union of } \\
\text { Bianibazar thana of Sylhet District. }\end{array}$ \\
\hline CIRDAP (2002) & $\begin{array}{l}\text { Community Fisheries Project Assessment in an area } \\
\text { where also remittance receiving households live. } \\
\text { Survey among 70 out of 500 beneficiary households of } \\
\text { the project, in six villages of Pankowri (Atiakhola, } \\
\text { Danuakhola, Charipara, Hasherkhola and } \\
\text { Patchpukuria). }\end{array}$ \\
\hline $\begin{array}{l}\text { Habibullah (1980, cited } \\
\text { in Murshid et al., 2002) }\end{array}$ & $\begin{array}{l}\text { Survey among 554 migrants in the districts of Dhaka, } \\
\text { Chittagong and Sylhet. }\end{array}$ \\
\hline Hossain (2001) & $\begin{array}{l}\text { Survey among 1,176 migrants (internal and overseas) } \\
\text { and their households in ten rural villages of the Comilla } \\
\text { District. }\end{array}$ \\
$\begin{array}{l}\text { Survey among 209 households in Charmeasha village } \\
\text { in the district of Chandpur. The focus of the research } \\
\text { was credit. A number of households also received } \\
\text { remittances. }\end{array}$ \\
\hline Hussain (1996)
\end{tabular}


ANNEX A (cont.)

MICRO-LEVEL STUDIES ON MIGRANTS (AND REMITTANCES) IN BANGLADESH ${ }^{72}$

\begin{tabular}{|c|c|}
\hline Reference & Description \\
\hline $\begin{array}{l}\text { INSTRAW and IOM } \\
(2000)\end{array}$ & $\begin{array}{l}\text { Survey among } 200 \text { female migrant households, of } \\
\text { which } 135 \text { were returned women migrants and } 15 \\
\text { women migrants on holidays. Most of the women } \\
\text { migrants were or had been working in the Middle East } \\
\text { or Malaysia. }\end{array}$ \\
\hline Iredale and Guo (2001) & $\begin{array}{l}\text { Survey among about } 100 \text { returned skilled and business } \\
\text { migrants. }\end{array}$ \\
\hline Kuddus (2003) & $\begin{array}{l}\text { Survey among } 17 \text { expatriate Bangladeshis, mostly living } \\
\text { in the USA. }\end{array}$ \\
\hline $\begin{array}{l}\text { Kuhn (2001 and 2002) } \\
\text { and Kuhn and Menken } \\
(2002)\end{array}$ & $\begin{array}{l}\text { Series of studies based on surveys, interviews and } \\
\text { censuses in the Matlab thana and with people who } \\
\text { migrated from Matlab to Dhaka. }\end{array}$ \\
\hline Mahmood (1991) & $\begin{array}{l}\text { Survey of } 368 \text { returned migrants to the Middle East } \\
\text { coming from the districts of Chittagong, Noakhali, } \\
\text { Sylhet and Dhaka in } 1985 .\end{array}$ \\
\hline Mahmood (1992) & $\begin{array}{l}\text { Survey of Mahmood (1991) supplemented by interviews } \\
\text { with } 50 \text { migrant households in the districts of } \\
\text { Chittagong, Noakhali, Sylhet and Dhaka. }\end{array}$ \\
\hline $\begin{array}{l}\text { Mahmood (1991, cited } \\
\text { in Murshid et al., 2002) }\end{array}$ & $\begin{array}{l}\text { Survey of } 510 \text { returnee migrants from Japan with } \\
\text { families in Munshgonj and Dhaka. }\end{array}$ \\
\hline Murshid et al. (2002) & $\begin{array}{l}\text { Survey among } 191 \text { households with current migrants, } \\
\text { returned migrants or would be migrants in eight villages } \\
\text { in the thana's of Fatikchari, Beanibazar, Muradnagar } \\
\text { and Chatkhil, located in the respective districts of } \\
\text { Chittagong, Sylhet, Comilla and Noakhali. }\end{array}$ \\
\hline RMMRU (2002) & $\begin{array}{l}\text { Survey among } 200 \text { returnee migrants in the districts of } \\
\text { Dhaka, Comilla, Madaripur and Chittagong. }\end{array}$ \\
\hline Siddiqui (2004b) & $\begin{array}{l}\text { Survey among } 82 \text { Bangladeshi expatriates residing in } \\
\text { New York, USA, and } 52 \text { in London, UK. }\end{array}$ \\
\hline $\begin{array}{l}\text { Siddiqui and Abrar } \\
\text { (2001) }\end{array}$ & $\begin{array}{l}\text { Survey among } 100 \text { remittance receiving families in the } \\
\text { thana's of Mirershai, Chittagong district and Kalihati, } \\
\text { Tangail district, and } 20 \text { remittance sending labour } \\
\text { migrants in Ajman and Dubai in the UAE. }\end{array}$ \\
\hline $\begin{array}{l}\text { Siddiqui and Abrar } \\
(2002)\end{array}$ & $\begin{array}{l}\text { Survey among } 200 \text { returnee migrants in the districts of } \\
\text { Dhaka, Comilla, Madaripur and Chittagong. }\end{array}$ \\
\hline
\end{tabular}


ANNEX B

\begin{tabular}{|c|c|c|c|c|c|c|c|c|c|c|c|c|}
\hline & $\begin{array}{l}\mathbb{D} \\
\frac{\mathbb{Z}}{\square}\end{array}$ & & 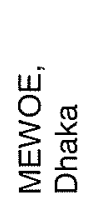 & 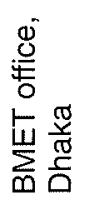 & & 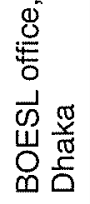 & & $\begin{array}{l}\frac{\widetilde{N}}{\mathbb{N}} \\
\frac{\tilde{D}}{0} \\
\underline{\Sigma} \\
\underline{0}\end{array}$ & & 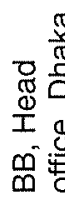 & & 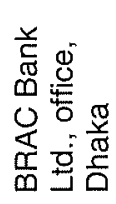 \\
\hline & 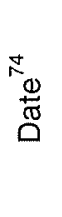 & & 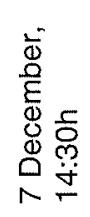 & 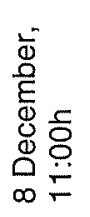 & & 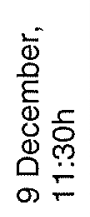 & & 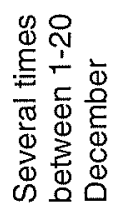 & & 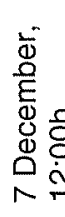 & & 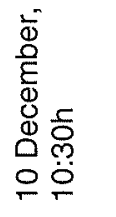 \\
\hline 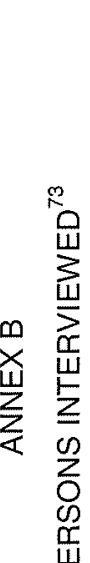 & 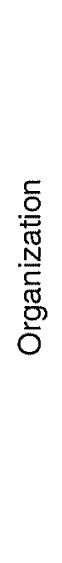 & & 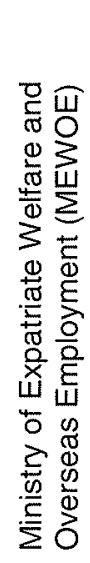 & 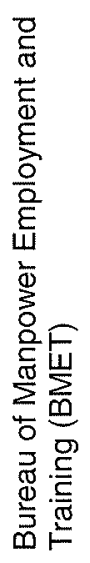 & & 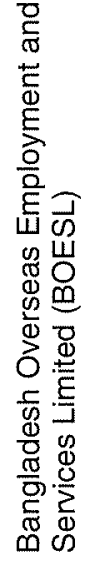 & & 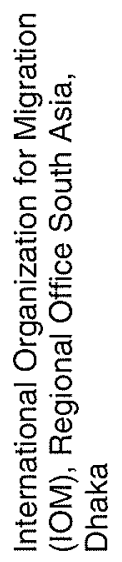 & & 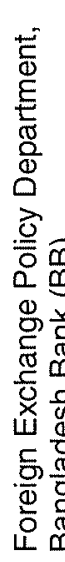 & & 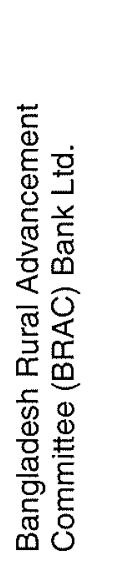 \\
\hline & 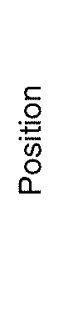 & & 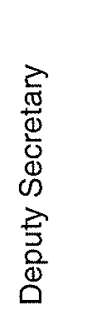 & 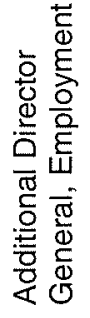 & 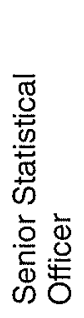 & 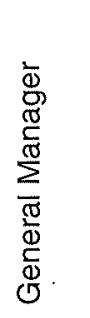 & & 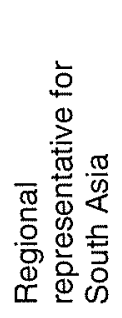 & &  & 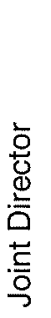 & $\begin{array}{l}\frac{\vec{T}}{0} \\
\frac{0}{9} \\
\frac{0}{0} \\
\frac{2}{0} \\
0 \\
\stackrel{0}{7}\end{array}$ \\
\hline & $\begin{array}{l}\stackrel{\tilde{E}}{\tilde{\pi}} \\
\mathcal{Z}\end{array}$ & 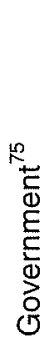 & 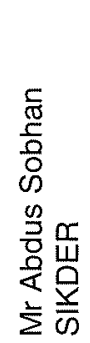 & 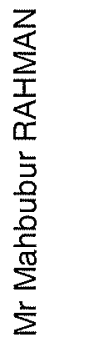 & 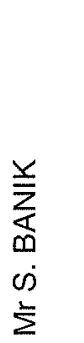 & 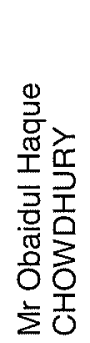 & 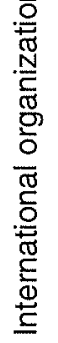 & 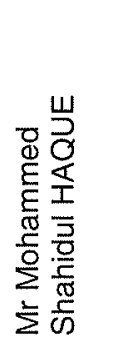 & 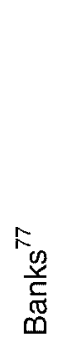 &  &  & 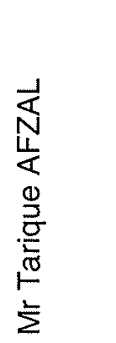 \\
\hline
\end{tabular}




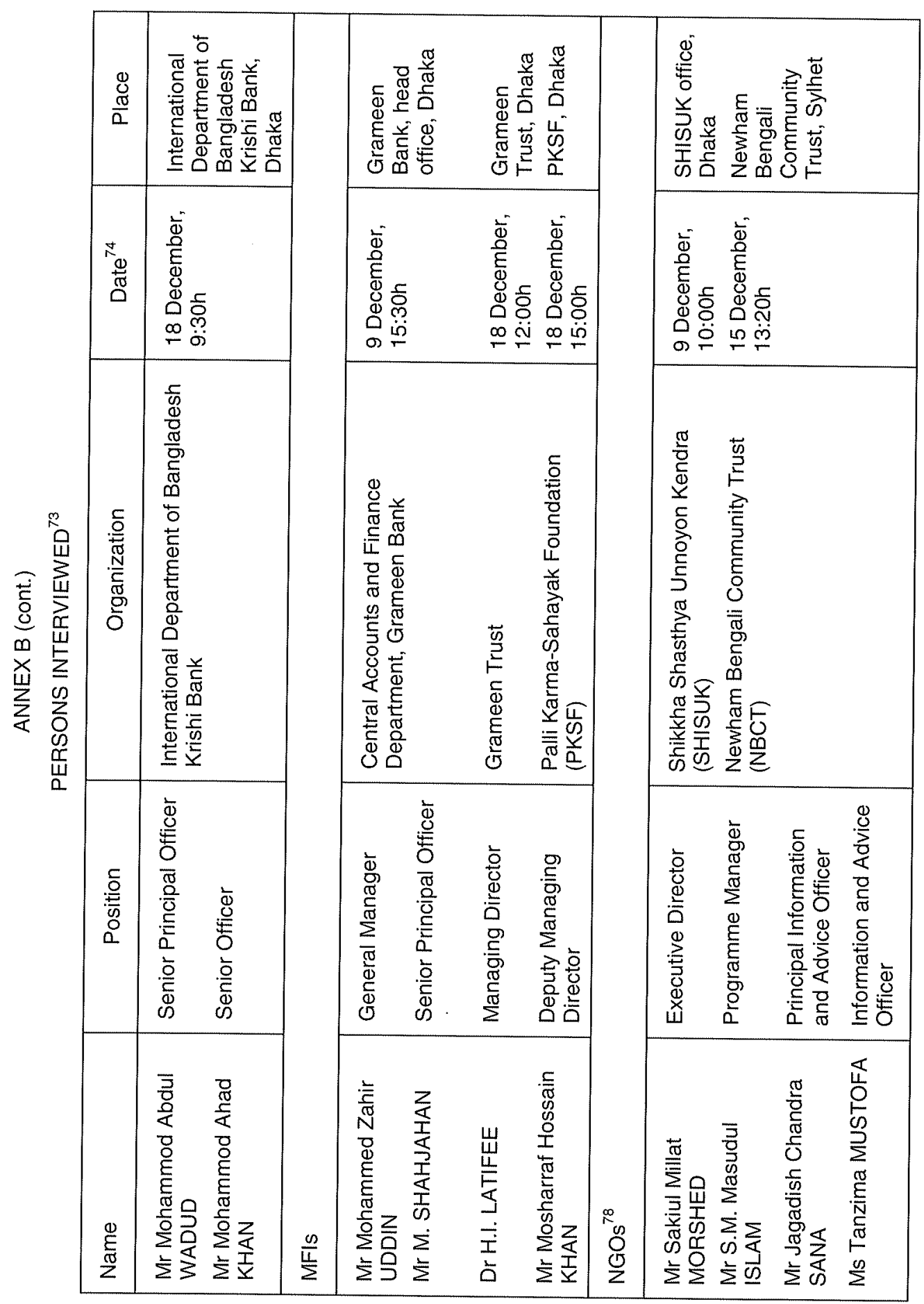




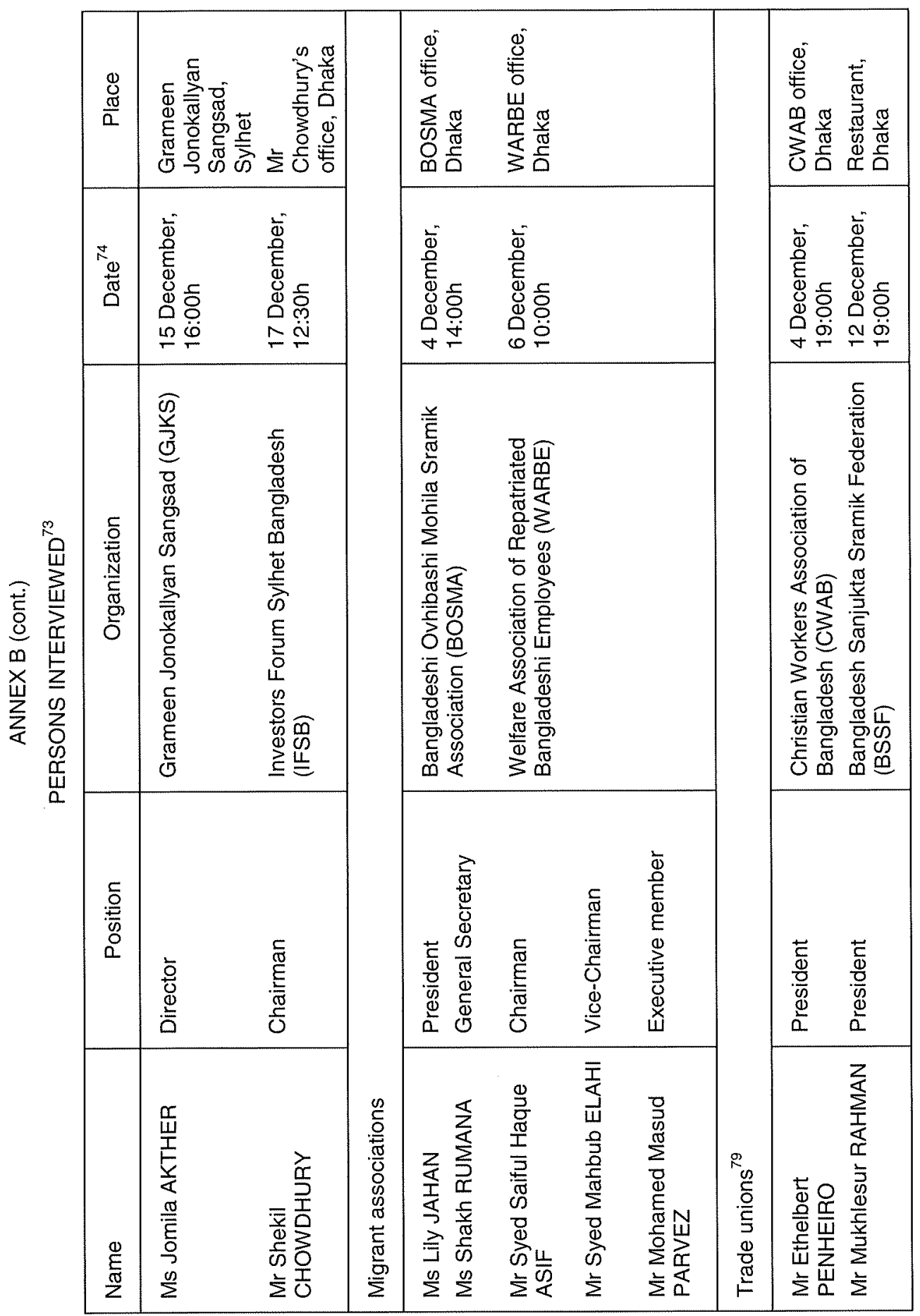




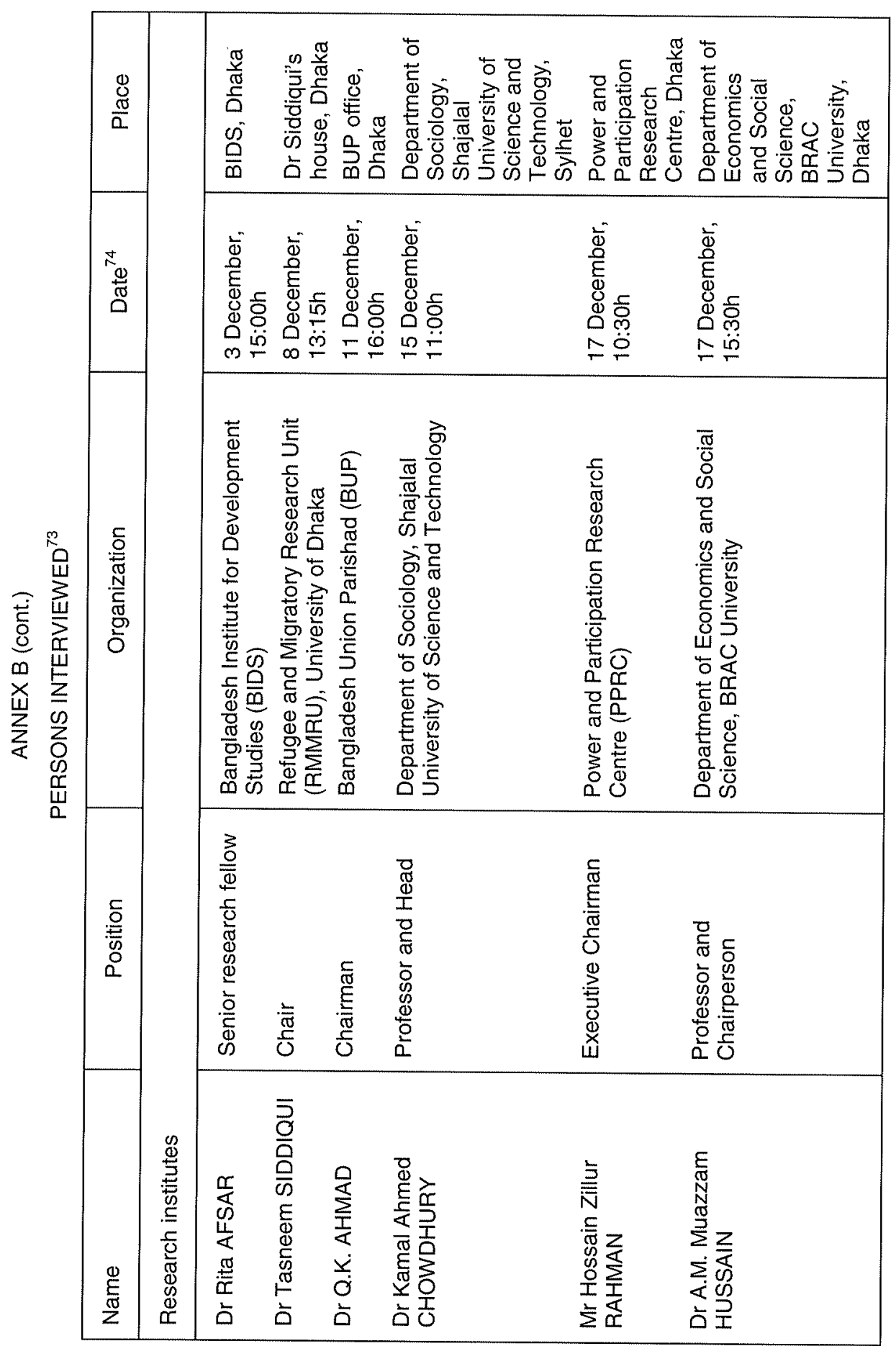




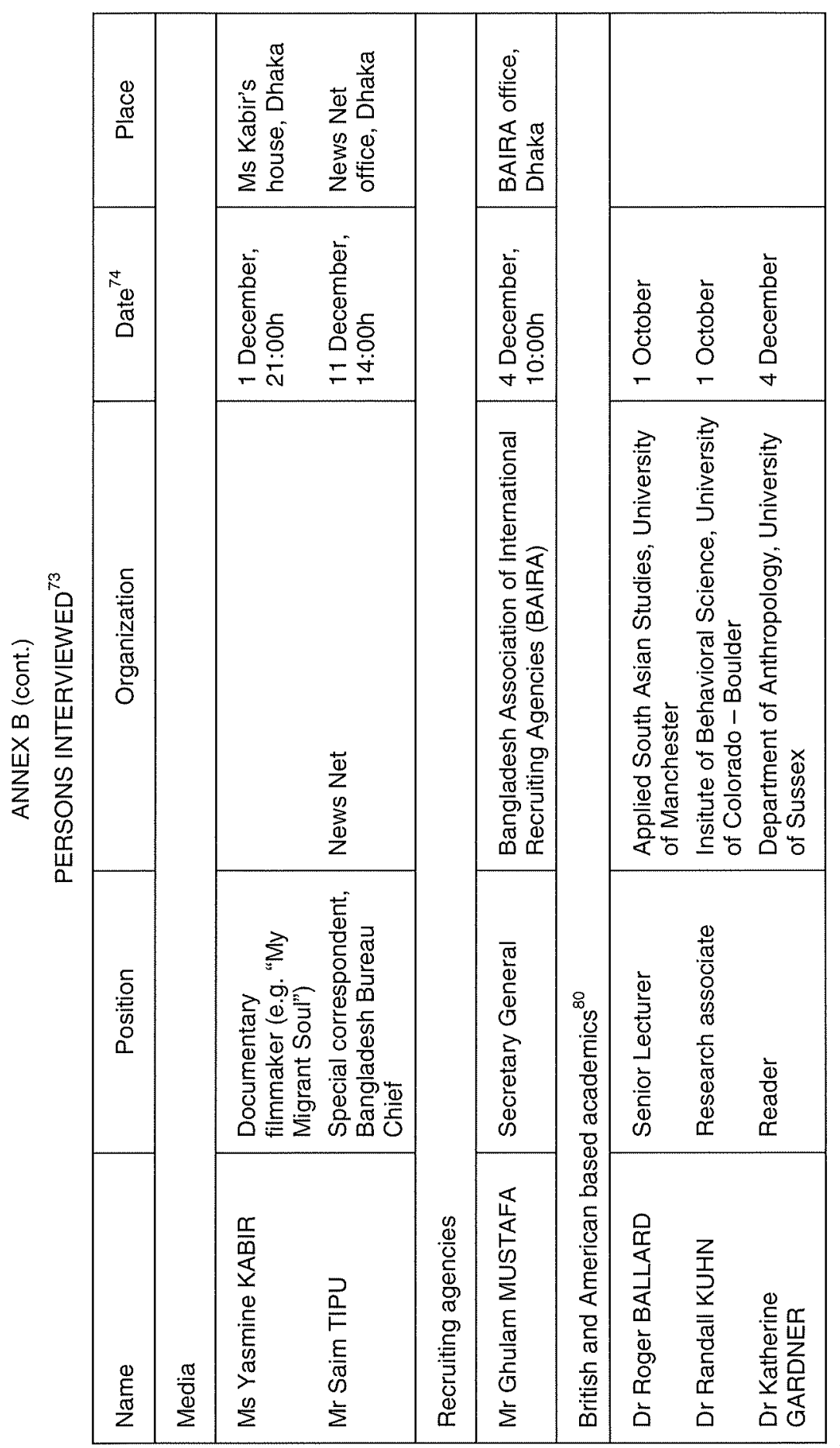




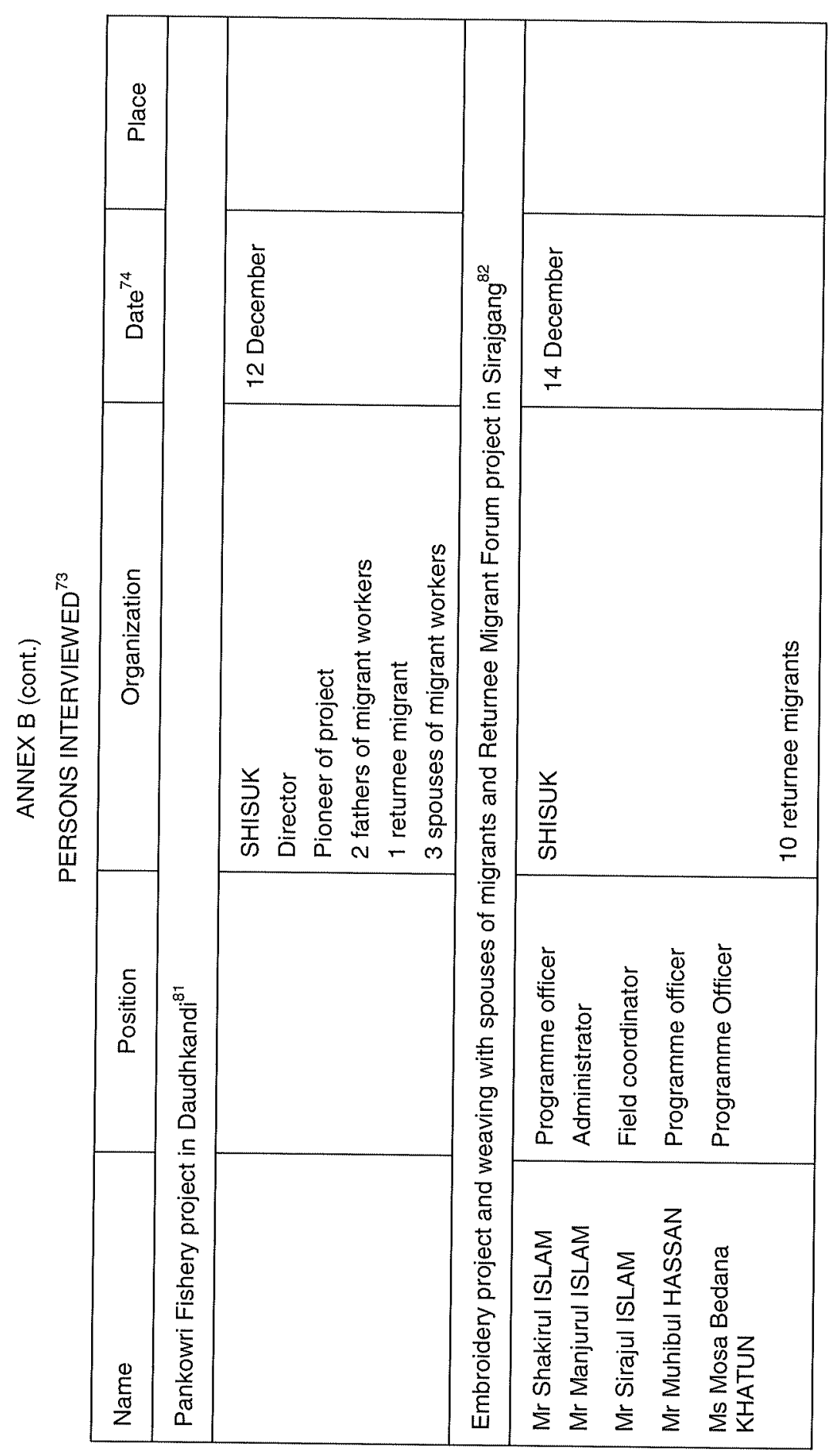




\section{ANNEX C}

ANNEX C

OFFICIAL MIGRATION FROM BANGLADESH

BY COUNTRY OF EMPLOYMENT AND REMITTANCE FLOW (1976-2004)

\begin{tabular}{|c|c|c|c|c|c|c|c|}
\hline Year & $\begin{array}{l}\text { Saudi } \\
\text { Arabia }\end{array}$ & Kuwait & UAE & Qatar & Iraq & Libya & Bahrain \\
\hline 1976 & 217 & 643 & 1,989 & 1,221 & 587 & 173 & 335 \\
\hline 1977 & 1,379 & 1,315 & 5,819 & 2,262 & 1,238 & 718 & 870 \\
\hline 1978 & 3,212 & 2,243 & 7,512 & 1,303 & 1,454 & 2,394 & 762 \\
\hline 1979 & 6,476 & 2,298 & 5,069 & 1,383 & 2,363 & 1,969 & 827 \\
\hline 1980 & 8,695 & 3,687 & 4,847 & 1,455 & 1,927 & 2,976 & 1,351 \\
\hline 1981 & 13,384 & 5,464 & 6,418 & 2,268 & 13,153 & 4,162 & 1,392 \\
\hline 1982 & 16,294 & 7,244 & 6,863 & 6,252 & 12,898 & 2,071 & 2,037 \\
\hline 1983 & 12,928 & 10,283 & 6,615 & 7,556 & 4,932 & 2,209 & 2,473 \\
\hline 1984 & 20,399 & 5,627 & 5,185 & 2,726 & 4,701 & 3,386 & 2,300 \\
\hline 1985 & 37,133 & 7,384 & 8,336 & 4,751 & 5,051 & 1,514 & 2,965 \\
\hline 1986 & 27,235 & 10,286 & 8,790 & 4,847 & 4,728 & 3,111 & 2,597 \\
\hline 1987 & 39,292 & 9,559 & 9,953 & 5,889 & 3,847 & 2,271 & 2,055 \\
\hline 1988 & 27,622 & 6,524 & 13,437 & 7,390 & 4,191 & 2,759 & 3,268 \\
\hline 1989 & 39,949 & 12,404 & 15,184 & 8,462 & 2,573 & 1,609 & 4,830 \\
\hline 1990 & 57,486 & 5,957 & 8,307 & 7,672 & 2,700 & 471 & 4,563 \\
\hline 1991 & 75,656 & 28,574 & 8,583 & 3,772 & 0 & 1,124 & 3,480 \\
\hline 1992 & 93,132 & 34,377 & 12,975 & 3,251 & 0 & 1,617 & 5,804 \\
\hline 1993 & 106,387 & 26,407 & 15,810 & 2,441 & 0 & 1,800 & 5,396 \\
\hline 1994 & 91,385 & 14,912 & 15,051 & 624 & 0 & 1,864 & 4,233 \\
\hline 1995 & 84,009 & 17,492 & 14,686 & 71 & 0 & 1,106 & 3,004 \\
\hline 1996 & 72,734 & 21,042 & 23,812 & 112 & 0 & 1,966 & 3,759 \\
\hline 1997 & 106,534 & 21,126 & 54,719 & 1,873 & 0 & 1,934 & 5,010 \\
\hline 1998 & 158,715 & 25,444 & 38,796 & 6,806 & 0 & 1,254 & 7,014 \\
\hline 1999 & 185,739 & 22,400 & 32,344 & 5,611 & 0 & 1,744 & 4,639 \\
\hline 2000 & 144,618 & 594 & 34,034 & 1,433 & 0 & 1,010 & 4,637 \\
\hline 2001 & 137,248 & 5,341 & 16,252 & 223 & 0 & 450 & 4,371 \\
\hline 2002 & 163,269 & 15,769 & 25,462 & 552 & 0 & 1,574 & 5,421 \\
\hline 2003 & 162,131 & 26,722 & 37,346 & 94 & 0 & 2,855 & 7,482 \\
\hline $\begin{array}{l}2004 \\
\text { (Jan- } \\
\text { Sep) }\end{array}$ & 115,074 & 31,334 & 34,352 & 934 & 0 & 462 & 6,694 \\
\hline Total & $2,008,332$ & 382,452 & 478,546 & 93,234 & 66,343 & 52,553 & 103,569 \\
\hline
\end{tabular}

Source: BMET figures of 2004, http://www.bmet.org.bd/Flow_Migration.htm. 
ANNEX C (cont.)

OFFICIAL MIGRATION FROM BANGLADESH

BY COUNTRY OF EMPLOYMENT AND REMITTANCE FLOW (1976-2004)

\begin{tabular}{|c|c|c|c|c|c|c|c|}
\hline Year & Oman & Malaysia & Korea & Singapore & Other & $\begin{array}{l}\text { Total } \\
\text { (in } \\
1000)\end{array}$ & $\begin{array}{c}\text { Remittances } \\
\text { (in million } \\
\text { US } \$ \text { ) }\end{array}$ \\
\hline 1976 & 113 & 0 & 0 & 0 & 809 & 6 & 24 \\
\hline 1977 & 1,492 & 0 & 0 & 0 & 632 & 16 & 83 \\
\hline 1978 & 2,877 & 23 & 0 & 0 & 1,029 & 23 & 107 \\
\hline 1979 & 3,777 & 0 & 0 & 110 & 223 & 24 & 172 \\
\hline 1980 & 4,745 & 3 & 0 & 385 & 2 & 30 & 301 \\
\hline 1981 & 7,352 & 0 & 0 & 1,083 & 1,111 & 56 & 305 \\
\hline 1982 & 8,248 & 0 & 0 & 331 & 524 & 63 & 491 \\
\hline 1983 & 11,110 & 23 & 0 & 178 & 913 & 59 & 628 \\
\hline 1984 & 10,448 & 0 & 0 & 718 & 1,224 & 57 & 500 \\
\hline 1985 & 9,218 & 0 & 0 & 792 & 550 & 78 & 500 \\
\hline 1986 & 6,255 & 530 & 0 & 25 & 254 & 69 & 576 \\
\hline 1987 & 440 & 0 & 0 & 0 & 711 & 74 & 748 \\
\hline 1988 & 2,219 & 2 & 0 & 0 & 709 & 68 & 764 \\
\hline 1989 & 15,429 & 401 & 0 & 229 & 654 & 102 & 758 \\
\hline 1990 & 13,980 & 1,385 & 0 & 776 & 517 & 104 & 782 \\
\hline 1991 & 23,087 & 1,628 & 0 & 642 & 585 & 147 & 769 \\
\hline 1992 & 25,825 & 10,537 & 0 & 313 & 293 & 188 & 902 \\
\hline 1993 & 15,866 & 67,938 & 0 & 1,739 & 724 & 245 & 1,009 \\
\hline 1994 & 6,470 & 47,826 & 1,558 & 391 & 2,012 & 186 & 1,154 \\
\hline 1995 & 20,949 & 35,174 & 3,315 & 3,762 & 3,975 & 188 & 1,202 \\
\hline 1996 & 8,691 & 66,631 & 2,759 & 5,304 & 4,904 & 212 & 1,355 \\
\hline 1997 & 5,985 & 2,844 & 889 & 27,401 & 2,762 & 231 & 1,525 \\
\hline 1998 & 4,779 & 551 & 578 & 21,728 & 2,602 & 268 & 1,599 \\
\hline 1999 & 4,045 & 0 & 1,501 & 9,596 & 563 & 268 & 1,807 \\
\hline 2000 & 5,258 & 17,237 & 990 & 11,095 & 1,780 & 223 & 1,955 \\
\hline 2001 & 4,561 & 4,921 & 1,561 & 9,615 & 4,422 & 189 & 2,071 \\
\hline 2002 & 3,854 & 85 & 28 & 6,856 & 2,386 & 225 & 2,848 \\
\hline 2003 & 4,029 & 28 & 3,771 & 5,304 & 4,428 & 254 & 3,178 \\
\hline $\begin{array}{l}2004 \\
\text { (Jan- } \\
\text { Sep) }\end{array}$ & 3,267 & 171 & 215 & 5,190 & 8,522 & 206 & 2,352 \\
\hline Total & 234,369 & 257,938 & 17,165 & 113,563 & 49,820 & 3,858 & 30,462 \\
\hline
\end{tabular}


ANNEX D

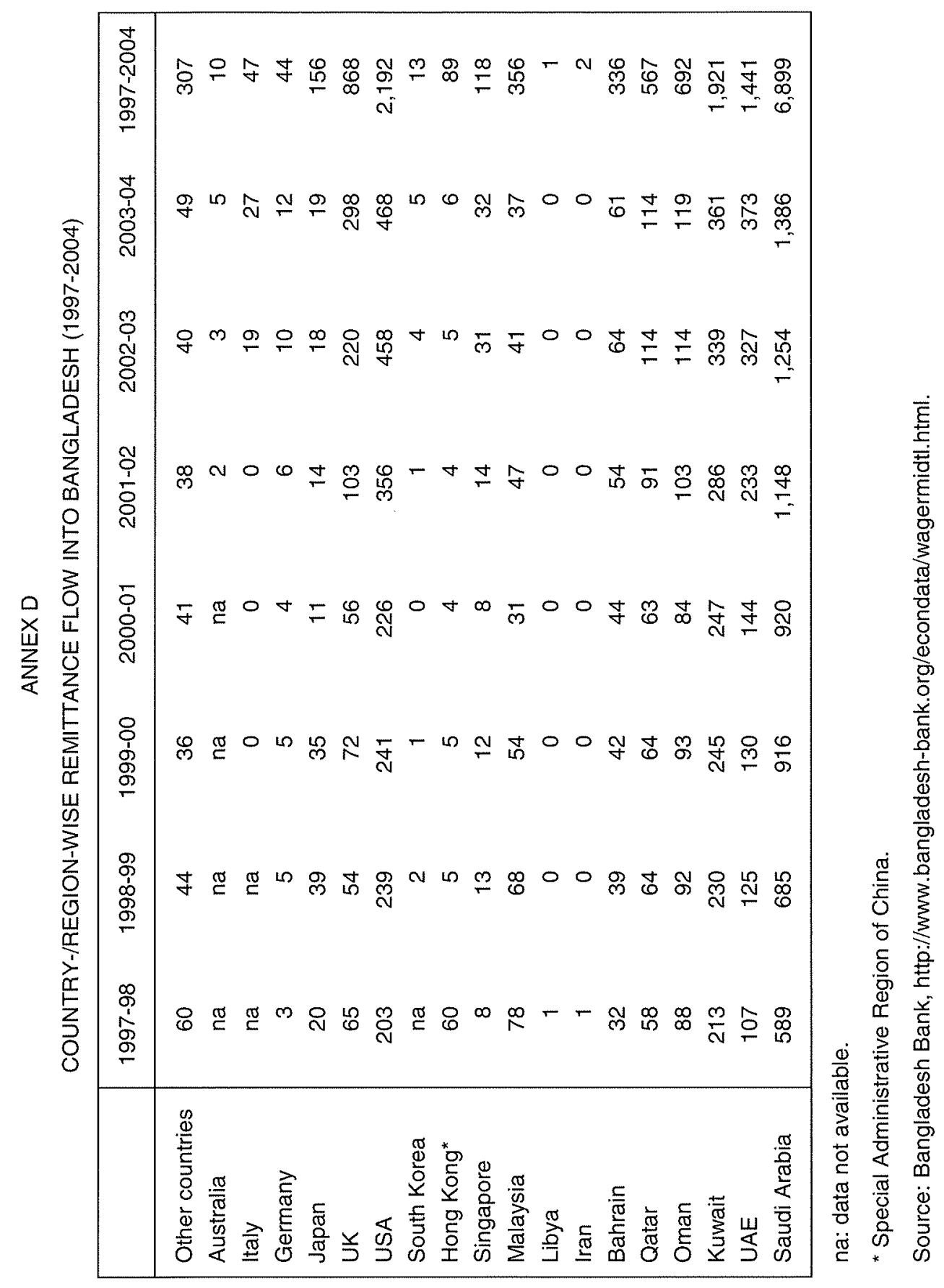




\section{ANNEX E}

\section{List of Bangladeshi and international studies and papers that explore possible avenues to enhance the development impact of remittances ${ }^{83}$}

\section{Bangladeshi studies and papers}

Focus on (higher) income diaspora:

Kuddus, U. (2003), Channeling Diaspora Remittance into the Securities Market of Bangladesh.

Siddiqui, T. (2004b), Institutionalizing Diaspora Linkage. The Emigrant Bangladeshis in UK and USA.

Focus on labour migrants:

Afsar, R., M. Yunus, and A.B.M.S. Islam (2002), Are Migrants after the "Golden Deer" ? A Study on Cost-Benefit Analysis of Overseas Migration by the Bangladeshi Labour:

Murshid, K.A.S., K. Iqbal, and M. Ahmed (2002), A Study on Remittance Inflows and Utilization.

Siddiqui, T. (2003), "Migration as a livelihood strategy of the poor: the Bangladesh case".

Siddiqui, T., and C.R. Abrar (2001), Migrant Worker Remittances and MicroFinance in Bangladesh.

\section{International studies and papers}

Bair, S.C. (2003), Improving Access to the U.S. Banking System Among Recent Latin American Immigrants: list of initiatives aimed at improving access to banking systems.

CARANA Corporation (2004), Diasporas, Émigrés and Development. Economic Linkages and Programmatic Responses: list of initiatives to enhance impact of individual remittances (channeling and use); collective remittances for community development purposes; diaspora based investment instruments.

CFSI (2004), Migrations et phénomènes migratoires. Flux financiers, mobilisation de l'épargne et investissement local: list of initiatives aimed at enhancing the development impact of individual and collective remittances; remittance use for local investment and for house construction. 
De Bruyn, T., and J. Wets (2004), Migrantentransfers als ontwikkelingsinstrument. Wat kan de overheid doen? [Remittances as a Development Tool. What Could Governments Do?]: list of existing initiatives as well as recommendations for governments of remittance sending countries aimed at enhancing the development impact of remittances.

DFID and World Bank (2003), International Conference on Migrant Remittances: Development Impact, Opportunities for the Financial Sector and Future Prospects. Report and Conclusions: various recommendations aimed at improving the development potential of remittances.

House of Commons International Development Committee (2004), Migration and Development: How to Make Migration Work for Poverty Reduction: various recommendations for the UK government aimed at improving the development potential of remittances.

Multilateral Investment Fund (MIF) of the Inter-American Investment Bank: website http://iadb.org/mif/V2/remittances.html: list of studies and projects aimed at enhancing the development impact of remittances from the US to Latin America. World Bank (2004), Global Development Finance. Harnessing Cyclical Gains for Development: recommendations for decreasing transaction costs. 


\section{Abbreviations}

$\begin{array}{ll}\text { ASK } & \text { Ain O Shalish Kendra } \\ \text { ATM } & \text { automatic teller machine } \\ \text { BAIRA } & \text { Bangladesh Association of International Recruiting Agencies } \\ \text { BB } & \text { Bangladesh Bank } \\ \text { BIDS } & \text { Bangladesh Institute for Development Studies } \\ \text { BLAST } & \text { Bangladesh Legal Aid Service Trust } \\ \text { BMET } & \text { Bureau of Manpower Employment and Training } \\ \text { BOESL } & \text { Bangladesh Overseas Employment and Services Limited } \\ \text { BOMSA } & \text { Bangladeshi Ovhibashi Mohila Sramik Association } \\ \text { BRAC } & \text { Bangladesh Rural Advancement Committee } \\ \text { BSEHR } & \text { Bangladesh Society for Enforcement of Human Rights } \\ \text { BSSF } & \text { Bangladesh Sanjukta Sramik Federation } \\ \text { BUP } & \text { Bangladesh Union Parishad } \\ \text { BWMA } & \text { Bangladeshi Women Migrant Association } \\ \text { CARAM } & \text { Coordination of Action Research on Aids and Mobility } \\ \text { CCDB } & \text { Christian Commission for the Development of Bangladesh } \\ \text { CDI } & \text { community development initiatives } \\ \text { CIRDAP } & \text { Centre on Integrated Rural Development for Asia and the Pacific } \\ \text { CWAB } & \text { Christian Workers Association of Bangladesh } \\ \text { DFID } & \text { Department for International Development of the UK } \\ \text { GCC } & \text { Gulf Cooperation Council } \\ \text { GJKS } & \text { Grameen Jonokallyan Sangsad } \\ \text { HIVA } & \text { Hoger Instituut voor de Arbeid (Higher Institute for Labour } \\ \text { IADB } & \text { Studies) } \\ \text { IAS } & \text { Inter-American Development Bank } \\ \text { IBBL } & \text { Islamigration Advisory Service } \\ \text { IDG BBPA } & \text { International Development Group of the British-Bangladeshi } \\ \text { IFSB } & \text { Professionals Association } \\ \text { ILO } & \text { Investors Forum Sylhet Bangladesh } \\ \text { INRB } & \text { International Labour Organization } \\ \text { INSTRAW } & \text { United Nations International Research and Training Institute } \\ \text { for the Advancement of Women } \\ \text { International Organization for Migration } \\ \end{array}$


MFI micro-finance institution

MEWOE Ministry of Expatriate Welfare and Overseas Employment

MIF Multilateral Investment Fund

NCB nationalized commercial bank

NBCT Newham Bengali Community Trust

NFCD non-resident foreign currency deposit

NGO non-governmental organization

NITA non-resident taka account

PCB private commercial bank

PKSF Palli Karma-Sahayak Foundation

PPRC Power and Participation Research Centre

RFCD resident foreign currency deposit

RMMRU Refugee and Migratory Movements Research Unit

SHISHUK Shikkha Shastha Unnayan Karzakram

UAE United Arab Emirates

UK United Kingdom

UN United Nations

US or USA United States or United States of America

WARBE Welfare Association of Repatriated Bangladeshi Employees

WOCCU World Council of Credit Unions 


\section{EXECUTIVE SUMMARY}

\section{Introduction and methodology}

In recent years politicians and academics have discovered the importance of remittances for the economic development of the origin countries of migrant communities.

This report, funded by the Flemish Interuniversity Council (VLIR) and carried out by the Higher Institute for Labour Studies (HIVA) in collaboration with the International Organization for Migration (IOM), Dhaka, takes Bangladesh as a case study. More specifically, it focuses on the impact of remittances on the household and the broader community; the initiatives taken by the government and other actors to enhance this impact; and the hindrances, opportunities and possible avenues for the enhancement of the impact of remittances on the broader society.

The report draws extensively on secondary sources, interviews as well as the existing literature, and thus brings together the existing knowledge in Bangladesh on the issue.

\section{Emigration patterns and dynamics in Bangladesh}

International remittances are sent mainly by three large, but distinct types of migrant. Firstly, there is an important, mainly American and British, diaspora of well-educated, high or middle income earners. Secondly, a diaspora of Bangladeshi origin also exists, in the same countries and other industrialized countries, belonging to the low-income or unemployed segments of the population. Thirdly, there is a major group of migrant labourers, who are residing for a specific period of time in Middle Eastern (mainly Saudi Arabia, UAE, Kuwait), South-East Asian (Malaysia, Singapore) and some industrialized countries. The first two groups amount to more than a million emigrants, while in the last 29 years about 3.8 million Bangladeshis have been officially recorded as migrant labourers.

Bangladeshi international migrants see themselves faced with a number of problems during the migration process: the cost of migration; exploitation by recruitment agencies and foreign employers; xenophobia towards Bangladeshis in the host countries; lack of appropriate measures to protect the rights of labour migrants; weak representation of migrant workers; and limited attention given to migrant workers by civil society. 


\section{Volume, dynamics and impact of remittances}

Between 1976 and 2002 Bangladesh received US\$30,400 million in official remittances. In the last years official remittances have increased to US\$ 3.8 billion annually. Most international remittances come from the Middle East and thus from temporary migrant workers. Saudi Arabia accounts for more than 40 per cent. The diaspora also takes a large share, with the USA accounting for 14 per cent of the remittance flow.

Besides official channels, money is remitted by hundi or hand carried by the migrant or friends or family of the migrant. These informal channels probably equal the amount sent by formal channels. The former are often quicker, cheaper (also in terms of exchange rate), easier, more accessible and more confidential than the latter. However, they can also be less reliable.

From the point of view of utilization, four different types of transfers can be discerned. Firstly and most importantly, individual transfers to families or friends. The available data shows that the bulk of remittances is used for consumption purposes. Investment in business or traditional productive uses and in savings is rather limited, but remittances are also seen as important financial means to investment in human capital (i.e. education), housing and land purchase. The importance of the repayment of the cost of migration should not be underestimated. Secondly, individual transfers are sent to save or invest in the home country, and thirdly to sponsor charity or community development initiatives. Lastly, collective transfers are identified to fund charity or community development initiatives.

Remittances contribute significantly to the national economy. The impact at the household level is less straightforward. On the plus side, remittances allow families to meet their basic needs; open up opportunities for investing in education, health care, etc.; loosen up constraints in the family budget to invest in business or to save; are a kind of emergency resource; provide a social security for the elderly; and can boost the local economy. The negative impacts of remittances are a possible dependency on this money flow and inflation. However, there is no conclusive evidence of the impact on income distribution. Possibly remittances could result in neglecting the local productive activities in the receiving areas.

\section{Initiatives and policies aimed at remittances}

The initiatives taken by governmental actors and other organizations involving remittances can be divided according to their aim. 
Firstly, policies are in place to enhance labour migration. Labour migration does not only result in remittances, but also acts as a strategy to combat unemployment.

Secondly, Bangladesh Bank and commercial banks have implemented policies to encourage and facilitate the use of official channels for transferring money. These include the provision of access to banking facilities; reform of official remittance channels; creation of special accounts; and awareness raising.

Thirdly, a number of actions and policies are aimed at attracting investment by non-residents. Examples are the launch of bonds; tax benefits; promotion of investment in Bangladesh and offering assistance.

Fourthly, some initiatives are taken to influence the use of remittances. It has been very difficult to find examples of initiatives that target the utilization of remittances. On the one hand, there are saving and investment schemes of banks and, on the other hand, an NGO offers opportunities for investing remittances.

\section{Hindrances and opportunities to enhance the impact of remittances on the broader society}

In the table the hindrances and opportunities are listed for using remittances for productive purposes which have an impact on the broader community. 


\section{HINDRANCES AND OPPORTUNITIES FOR USING REMITTANCES FOR PRODUCTIVE PURPOSES WHICH HAVE AN IMPACT ON THE BROADER COMMUNITY}

\begin{tabular}{|c|c|c|c|}
\hline & Labour migrants & Low income diaspora & High income diaspora \\
\hline \multirow{10}{*}{ 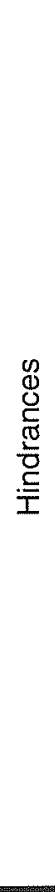 } & $\begin{array}{l}\text { Lack of financial means (due to } \\
\text { low wages, high migration costs, } \\
\text { exploited position..) }\end{array}$ & Lack of financial means & Distrust in government \\
\hline & $\begin{array}{l}\text { Pressure of family and ignorance } \\
\text { about migrant's situation in } \\
\text { destination country }\end{array}$ & $\begin{array}{l}\text { Lack of interest (future } \\
\text { is in new country) }\end{array}$ & $\begin{array}{l}\text { Bureaucracy and } \\
\text { lengthy procedure }\end{array}$ \\
\hline & $\begin{array}{l}\text { Lack of appropriate structures for } \\
\text { utilization of remittances for } \\
\text { productive purposes }\end{array}$ & $\begin{array}{l}\text { Lack of organizational } \\
\text { capacity of trusts }\end{array}$ & $\begin{array}{l}\text { Lack of information } \\
\text { about investment } \\
\text { possibilities }\end{array}$ \\
\hline & $\begin{array}{l}\text { Lack of knowledge to use } \\
\text { remittances for productive } \\
\text { purposes }\end{array}$ & $\begin{array}{l}\text { Trusts lack support of } \\
\text { official bodies }\end{array}$ & $\begin{array}{l}\text { Lack of structures for } \\
\text { investing in initiatives } \\
\text { which impact on the } \\
\text { wider community }\end{array}$ \\
\hline & $\begin{array}{l}\text { Lack of information about existent } \\
\text { structures }\end{array}$ & \multirow{4}{*}{$\begin{array}{l}\text { Competition from other } \\
\text { investment } \\
\text { opportunities }\end{array}$} & \multirow[t]{4}{*}{$\begin{array}{l}\text { Investment situation in } \\
\text { Bangladesh }\end{array}$} \\
\hline & Lack of political participation & & \\
\hline & Bad human rights situation & & \\
\hline & Lack of associations & & \\
\hline & \multicolumn{3}{|c|}{$\begin{array}{l}\text { Ministry of Expatriate Welfare and Employment (MEWOE) lacks financial and logistic } \\
\text { capacity }\end{array}$} \\
\hline & \multicolumn{3}{|c|}{ Lack of interest by government, NGOs, donors and research centres in the issue } \\
\hline \multirow{9}{*}{  } & $\begin{array}{l}\text { Small proportion of } \\
\text { income/remittances is saved or } \\
\text { invested however majority of } \\
\text { income is remitted }\end{array}$ & $\begin{array}{l}\text { Strong links with region } \\
\text { of origin (esp. Sylhet - } \\
\text { London) }\end{array}$ & $\begin{array}{l}\text { Financial means } \\
\text { available }\end{array}$ \\
\hline & $\begin{array}{l}\text { Successful pre-departure and } \\
\text { awareness programmes in place }\end{array}$ & $\begin{array}{l}\text { Trusts of Bangladeshi } \\
\text { migrant communities in } \\
\text { UK }\end{array}$ & $\begin{array}{l}\text { Willingness to invest in } \\
\text { Bangladesh }\end{array}$ \\
\hline & Willingness to invest & & \\
\hline & $\begin{array}{l}\text { Successful examples of structures } \\
\text { for effective utilization of } \\
\text { remittances in place }\end{array}$ & & \\
\hline & $\begin{array}{l}\text { Vast and well-established network } \\
\text { of MFls }\end{array}$ & & \\
\hline & \multicolumn{3}{|c|}{ Establishment of MEWOE } \\
\hline & \multicolumn{3}{|c|}{ Growing interest in remittances, labour migrants and diaspora } \\
\hline & \multicolumn{3}{|c|}{ Recognition of importance of remittances for national economy } \\
\hline & \multicolumn{3}{|c|}{ Initiatives in place to target channelling of remittances } \\
\hline
\end{tabular}




\section{Recommendations and conclusion}

When proposing policy measures, it must be kept in mind that remittances are private money flows. Therefore the role of the government should be focused on enabling migrants to send and use their remittances in the most effective ways, according to their own needs. Furthermore, the dynamics of remittance utilization and impact are very partial at the moment. Clearly, more research is needed on the following topics:

- The impact of remittances on the receivers and the senders, as well as on the broader community;

- The gender aspect of migration and remittances;

- The role of the diaspora, including collective remittances, so important in other migrant communities, such as the Mexicans in the US and West Africans in France;

- The use of remittances as a development tool in Bangladesh.

In a number of countries, governments, NGOs, financial institutions and research institutes are exploring new ways of addressing remittance senders and receivers' needs in terms of remittance methods and utilization. These initiatives (i.e. research and pilot programmes) are certainly worth studying in more detail and could inform the Bangladesh Government in its search for effective measures. In this report we have singled out pre-departure orientation programmes and incorporating MFIs in remittances.

Pre-departure training for labour migrants is not only important to reduce the human and economic costs of migration, it can also be a powerful tool in raising awareness about remittance methods and utilization. The involvement of a variety of actors (international institutions, migrant associations, NGOs and governmental bodies) is instrumental in the success of these initiatives.

Considering the extensive network of MFIs in Bangladesh and the fact that Bangladesh is one of the pioneers in issues involving micro-finance and micro-credit schemes on the one hand, and the successful implementation of linking MFIs to remittances in other countries on the other hand, MFIs involvement in remittances in Bangladesh could be one of the most promising avenues for optimizing the development impact of remittances. MFIs can as well function as distribution agents in remote areas (which they already do), as administer schemes which support the use of remittances for savings and investments for development. In this the possibility of matching fund schemes should be explored. 
A last, but important remark refers to social and human rights conditions of migrants. Although the focus of this paper has been the economic issue of remittances, the second chapter made it clear that the success of policies enhancing the development potential of remittances, is inextricably linked to improving the social and human rights conditions of (especially labour) migrants during the migration process (before, during and after migrating). 


\section{ENDNOTES}

1. Quote of Mr Mustafa of BAIRA in a personal interview.

2. Personal interview.

3. For a detailed account of migration of Sylhetans to the UK, and a comparison with migration flows from Mirpur, Pakistan and Jullundur Doab, India see Ballard, 2001 and 2002.

4. Personal interview with Mr Rahman and Mr Banik of BMET.

5. Personal interview.

6. More information on BOESL is provided below.

7. Interestingly and illustrative for the importance of the link between Sylhet and the UK is the fact that the only overseas office of IAS is based in Sylhet, notwithstanding that the charity deals with immigrants and asylum seekers from all over the world (see www.iasuk.org).

8. More information on BMET is provided below.

9. Personal interviews with Messrs Rahman and Banik of BMET, Mr Mustafa of BAIRA and Mr Morshed of SHISUK.

10. Personal interviews with Mr Sikder of MEWOE, Messrs Rahman and Banik of BMET and Mr Chowdhury of BOESL.

11. See IOM (2003) for a comparison with other Asian countries.

12. Personal interview with Mr Haque of IOM.

13. See IOM (2003) for a comparison with other Asian countries.

14. http://www.bmet.org.bd/Flow_Migration.htm.

15. When we take into account the 150,000 Bangladeshis who have migrated irregularly and have been legalized in 1997 , this figure reaches 400,000 migrant workers.

16. http://www.bmet.org.bd/Flow_Migration.htm.

17. BMET has classified temporary migrant workers in four categories. Professionals refer to doctors, engineers, nurses and teachers; skilled workers include manufacturing and garment workers; semi-skilled workers include tailors and masons; and housemaids, cleaners and labourers are considered as unskilled workers (Siddiqui and Abrar, 2001).

18. Research of Bradley and Taylor (2000) nuance these conclusions by conditioning the educational attainment figures on a number of potential determinants of educational outcomes. After controlling for other determinants, their results show that Bangladeshis and other non-white ethnic youths (with the exception of Afro-Caribbeans) perform better in exams than their white counterparts.

19. According to a survey by Afsar et al. (2002) with Bangladeshi migrant labourers in the UAE, a migrant spends on average 95,000 taka for the migration process to be completed. According to a survey by Abdul-Aziz (2001), Bangladeshi migrant labourers in Malaysia had to pay between US\$ 450 and US\$1,000 for their travel alone. Female migrant labourers to the Middle East have to pay US $\$ 1,000$ to 2,000 for visa fee and airfare, according to Afsar (2001); INSTRAW and IOM (2000), on the other hand, mention a much lower figure of 43,000 taka (or US\$ 840) which also includes insurance, passport, medical check, clothes and other items. 
20. These findings were confirmed in the personal interview with Ms Jahan and Ms Rumana of the Bangladeshi Ovhibashi Mohila Sramik Association (BOSMA). See also Blanchet (2002) for a more extensive account of the exploitation of women labour migrants.

21. One of the people we interviewed in Daudkandi reported a similar experience. Her husband was a migrant labourer in Malaysia. After his documents were taken away, he also ended up in a detention camp in Malaysia, were he died (see also Tahmina, 2003b).

22. The Gulf Cooperation Council (GCC) is the political organization that includes Saudi Arabia, Kuwait, Bahrain, Qatar, the UAE and Oman.

23. Personal interviews.

24. Under the name of BWMA.

25. http://www.bmet.org.bd/Flow_Migration.htm.

26. http://www.bangladesh-bank.org/econdata/wagermidtl.html.

27. Personal interviews with Mr Haque of IOM, Mr Sikder of MEWOE, Mr Uddin and Mr Azad of Bangladesh Bank and Mr Afzal of BRAC Bank.

28. See below for more on this issue.

29. This and the following information is compiled from the website of Bangladesh Bank: http://www.bangladesh-bank.org.

30. Personal interview.

31. The hundi system is not unique for Bangladesh. In India for instance it is known as hawala, in China as fei qian, and in other parts of the world as flying money (Berlage et al., 2003).

32. For more information on the history and the dynamics of the hundi or similar systems: see Ballard, 2003a and b; Grabben, 2002; Passas, 1999; Wilson, 2002; Wilson and Ballard, 2003.

33. This figure does not appear explicitly in the study of INSTRAW and IOM. On average the monthly income of the interviewed migrants during the migration period was 5,173 taka, which amounts to 62,076 taka a year. A little further, the authors mention that on average the amount of remittances sent by a worker in one year was equal to 45,126 taka. With these figures we can calculate the proportion of income which is remitted.

34. Personal interviews with, for instance, Dr Siddiqui of RMMRU, Prof. Ahmad of BUP and $\mathrm{Mr}$ Asif, Mr Elahi and Mr Parvez of WARBE.

35. Afsar (2003) even mentioned 90 per cent, for consumption purposes. However this entailed more than only food and clothing.

36. We will elaborate on these projects below.

37. These figures are remarkably high, and their accuracy may be questionable.

38. For instance Prof. Dr Ahmad of BUP, Mr Chowdhury of the Investors Forum Sylhet Bangladesh (IFSB), Ms Akther of Grameen Jonokallyan Sangsad (GJKS) and Prof. Dr Chowdhury of the Department of Sociology, Shajalal University of Science and Technology.

39. Zakat is the fifth ritualistic duty that, according to Islamic religion, every believer owes to God. It can be considered as a kind of alms giving or charity.

40. The union is the lowest level of administrative unit in Bangladesh.

41. Personal interviews with Ms Akther of GJKS, Dr Ahmad of BUP, M. Chowdhury of IFSB, Dr Siddiqui of RMMRU and Dr Chowdhury of Shajalal University. 
42. Future research is needed to find out more of these in the UK. Information is necessary on the amount of people who are involved in the pooling of resources, the amount of resources which has been pooled, the exact nature of the projects which are being financed, and the way in which the resources are channelled from the UK to the projects in Bangladesh.

43. See IOM 2002 for a Guatemalan example.

44. Murshid et al. 2002; Siddiqui 2003; Siddiqui and Abrar 2001; Jolly 2003; Skeldon 2003; Afsar 2001; Van Doorn 2002.

45. For a more detailed account of the relationship of migrant labourer's' remittances with macroeconomic indicators in Bangladesh see Afsar et al. (2002).

46. Personal interview.

47. Personal interview with Dr Rahman of PPRC.

48. Personal interview.

49. See, for instance, Thamina (2003a) for the concerns that spouses of migrant labourers experience when their husbands are abroad.

50. See also Bangladesh Bank's website for a list of exchange houses and links to other banks: http://www.bangladesh-bank.org.

51. Personal interview with Mr Afzal of BRAC Bank.

52. Personal interviews with Messrs Uddin and Shahjahan of Grameen Bank and Mr Latifee of Grameen Trust.

53. Personal interviews with Mr Uddin and Mr Azad of BB, Mr Afzal of BRAC Bank.

54. Personal interviews with Mr Rahman and Mr Banik of BMET, Mr Morshed of SHISUK, Mr Asif, Mr Elahi and Mr Parvez of WARBE.

55. Personal interview with Ms Jahan and Ms Rumana of BOSMA.

56. See also Bangladesh Bank's website: http:/www.bangladesh-bank.org/investpr/ invesfac.html.

57. See their website: http://bbcc.org.uk.

58. Personal interviews.

59. Since Bangladeshi trusts in the UK or the USA have not been well researched (to our knowledge), and an extensive survey of this organizations is beyond the scope of this research, the statements on trusts must be considered to be provisional (see also Chapter Three, 3.4).

60. Personal interviews with returnee migrants at WARBE, BOSMA and the Pankowri Fisheries Project and Migrants project in Sirajgang.

61. See for instance Orozco, 2000.

62. Personal communication with Damien Thuriaux, Programme Officer, Labour Migration Service Area of IOM.

63. Personal communication with Damien Thuriaux, Programme Officer, Labour Migration Service Area of IOM.

64. Damien Thuriaux of IOM also raises the interesting point of involving financial institutions in this process. They could benefit from market shares of the formally remitted funds (personal communication).

65. Personal interviews with Mr Islam, Mr Hassan and Ms Khatun of SHISUK (see also SHISUK, 2002).

66. See also Siddiqui 2004 a. 
67. For more detailed figures see websites of Grameen (http://www.grameen-info.org), BRAC (http://www.brac.net), ASA (http://www.asabd.org) and Proshika (http://www.proshika. org).

68. Personal interviews with Mr Afzal of BRAC Bank and Mr Uddin and Mr Shahjahan of Grameen Bank.

69. Personal interviews with returned migrants at BOSMA, WARBE and the Pankowri and Migrants project.

70. Personal interviews with Mr Uddin and Mr Sjajhahan of Grameen Bank, Dr Latifee of Grameen Trust and Dr Hussain of BRAC University.

71. See also their websites for more information. WOCCU: http://www.woccu.org; MIF of IADB: http://www.iadb.org/mif/v2/index.html.

72. This list is not exhaustive.

73. In footnote we mention the actors whom we approached but could not or did not want to be interviewed (due to time constraints, for instance), or told us that they did not work on the issue and thus could not give us relevant information.

74. All interviews were carried out in 2003.

75. District Commissioner of Sylhet.

76. International Labour Organization (ILO) Dhaka; Department for International Development of the UK (DFID) Dhaka; Immigration Advisory Service (IAS); British Council.

77. Sonali Bank.

78. Action Aid.

79. Bangladesh Institute for Labour Studies (BILS).

80. Contacted by e-mail for advice and information. The dates refer to the day when we sent our first mail to the person.

81. The date refers to the day the project was visited.

82. The date refers to the day the project was visited.

83. This list is non-exhaustive. For complete references and website links (if available) see list of references. 


\section{REFERENCES}

Abdul-Aziz, A.

2001 "Bangladeshi migrant workers in Malaysia's construction sector", Asia-Pacific Afsar, R.

Population Journal, 16(1), http://www.unescap.org/pop/journal/2001/v16n1a1.pdf.

1999a "Is migration transferring rural poverty to urban areas", in R. Afsar, M. Hossain and M.L. Bose, Changes and Determinants of Urban Poverty and Standard of Living of Dhaka City, Programme for Research on Poverty Alleviation Research Report Series, No. 145, Grameen Trust, Dhaka.

1999 b "Rural-urban migration: bane or boon. Re-examining the existing hypotheses on consequences of migration", in R. Afsar, M. Hossain and M.L. Bose, Changes and Determinants of Urban Poverty and Standard of Living of Dhaka City, Programme for Research on Poverty Alleviation Research Report Series, No. 145, Grameen Trust, Dhaka.

2001 Globalization, International Migration and the Need for Networking: The Bangladesh Perspective, http://www.sasnet.lu.se/afsarpaper.pdf.

2003 "Internal migration and the development nexus: the case of Bangladesh", paper presented at the Conference on Migration, Development and Pro-poor Policy Choices in Asia, Dhaka, 22-24 June, http://www.livelihoods.org/hot_topics/docs/ Dhaka_CP_6.pdf.

Afsar, R., M. Yunus, and A.B.M.S. Islam

2002 Are Migrants after the "Golden Deer"? A Study on Cost-Benefit Analysis of Overseas Migration by the Bangladeshi Labour; IOM, Regional Office for South Asia, Dhaka.

Ahmad, Q.K., and F. Zohora,

1997 Utilization of Remittances from Abroad for Local Employment Promotion - The Case of Sylhet, ILO, BUP, Dhaka.

Akbory, Y.

2003 Globalization: Public Capacity and Involving Diasporas for Development in Bair, S.C. Bangladesh, Ministry of Expatriate Welfare and Overseas Employment, Dhaka.

2003 Improving Access to the U.S. Banking System Among Recent Latin American Ballard, R.

Immigrants, http://www.iadb.org/mif/v2/files/28doca.pdf.

2001 "The impact of kinship on the economic dynamics of transnational networks: reflections on some South Asian developments", workshop on Transnational Migration, 29 June-1 July 2001, Princeton University, Princeton, http:// www.transcomm.ox.ac.uk/working\%20 papers/Ballard.pdf.

2002 "The South Asian presence in Britain and its transnational connections" in H. Singh, S. Vertovec (Eds) Culture and Economy in the Indian Diaspora, Routledge, London, http://www.art.man.ac.uk/CASAS/pdfpapers/southasian britain.pdf.

2003a A Background Report on the Operation of Informal Value Transfer Systems (Hawala), http://www. art.man.ac.uk/CASAS/pdfpapers/hawala.pdf. 
$2003 \mathrm{~b}$ "Processes of consolidation and settlement in remittance-driven Hawala transactions between the UK and South Asia", paper presented at a World Bank/ DFID International Conference on Migrant Remittances: Development Impact, Opportunities for the Financial Sector and Future Prospects, 8 and 10 October 2003, London.

Berlage, L., K. Havet, J. Leman, and H. Soenen

2003 Transfers van migranten: omvang en effecten, VLIR, Brussel/KULeuven, Leuven.

Black, R.

2003 Soaring Remittances Raise New Issues, http://www.migrationinformation.org/

Blanchet, $\mathrm{T}$. Feature/print.cfm?ID $=127$.

2002 Beyond Boundaries: A Critical Look at Women Labour Migration and the Trafficking Within, mimeo, USAID.

Bradley, S., and J. Taylor

2000 Ethnicity, Educational Attainment and the Transition from School, Lancaster University Management School, Lancaster, http://www.lums.co.uk/publications/ viewpdf $/ 30 /$.

CARANA Corporation

2004 Diasporas, Émigrés and Development. Economic Linkages and Programmatic Responses, USAID, TESS, http://www.tessproject.com/products/special_studies/ diasporas_emigres_\&_development.pdf.

\section{CFSI}

2004 Migrations et phénomènes migratoires. Flux financiers, mobilisation de l'épargne et investissement local, AFD, Paris, http://www.afd.fr/jahia/webdav/site/ myjahiasite/users/administrateur/public/ notes-strategiques/Migration-etphenomenes-migratoires-04-05-2004.pdf.

Chimhowu, A., J. Piesse, and C. Pinder

2003 "The socio-economic impact of remittances on poverty reduction", taken from Report on the Development of a Framework for Assessing the Socio-economic Impact of Migrant Workers' Remittances on Poverty Reduction, commissioned by DFID to WISE Development, Ltd, London.

Chowdhury, K.A.

1992 "The impact of foreign remittances on the receiving and non-receiving households in a Bangladesh village", South Asian Anthropologist, 13(1 and 2): 37-42.

1995 "Emigration and its effects on the labour exporting countries: a review of existing literature", Rajshahi University Studies, Part C, Vol. 3.

CIRDAP (Centre on Integrated Rural Development for Asia and the Pacific)

2002 Community Initiatives for Fisheries Development, CIRDAP, Dhaka.

De Bruyn, T., and J. Wets

2004 Migrantentransfers als ontwikkelingsinstrument. Wat kan de overheid doen?, VLIR, Brussel.

De Haan, A.

1999 "Livelihoods and poverty: the role of migration. A critical review of the migration literature" in Journal of Development Studies, June 1999, http:// wbln0018.worldbank.org/External/Urban/ UrbanDev.nsf/Attachments/ 
Livelihoods+and+poverty:+the+role+of+migration. + A+critical+review +of +the+ literature+Journal+of+Development+studies/\$File/miglirev.doc.

DFID and World Bank

2003 International Conference on Migrant Remittances: Development Impact, Opportunities for the Financial Sector and Future Prospects. Report and Conclusions, 9-10 October 2003, London, http://www.livelihoods.org/hot_topics/ docs/RemitConfFinal.doc.

El-Qorchi, $\mathrm{M}$.

2002 Hawala: How does this Informal Funds Transfer System Work and How Should it be Regulated?, http://www.imf.org/external/pubs/ft/fandd/2002/12/elqorchi.htm.

El-Sakka, M.I.T., and R. McNabb

1999 "The macro-economic determinants of emigrant remittances" World Development Report, 27(8): 1493-1502.

Embassy of Bangladesh, Washington DC

2008 "Facilitating homebound remittances", website of Embassy of Bangladesh, Washington DC, accessed 10 February 2004, [http://www.bangladoot.org/ Gardner, K. remittances.pdf].

1995 Global Migrants, Local Lives. Travel and Transformation in Rural Bangladesh, Clarendon Press, Oxford.

Grabben, J.O.

2002 "In praise of hawala", The Laissez Faire Electronic Times, 1(13), http:// freedom.orlingrabbe.com/ lftimes/hawala.htm.

Hassan, $M$.

2000 "Complementarity between international migration and trade: a case study of Bangladesh" Journal of Bangladesh Studies, 1(2), http://www.aedsb.org/JBSJune2000-MunirHassan.doc

Hossain, M.Z.

2001 "Rural-urban migration in Bangladesh: a micro-level study" paper presented at $24^{\text {th }}$ IUSSP General Conference, Salvador, Brazil, 18-24 August, http:// www.iussp.org/Brazi12001/s20/S28_P02_Hossain.pdf.

House of Commons International Development Committee

2004 Migration and Development: How to Make Migration Work for Poverty Reduction. Sixth Report of Session 2003-2004, House of Commons, London, Hussain, M.A. www.parliament.uk/parliamentary_committees/international_development.cfm.

1996 Credit in the Fishing Communities: A Case Study of a Fishing Village in Meghna Delta, Programme for Research on Poverty Alleviation Research Report Series, No. 59, Grameen Trust, Dhaka.

ILO

2000 Making the Best of Globalization: Migrant Worker Remittances and Micro-Finance. Workshop Report, 20-21 November 2000, ILO, Geneva, http://www.ilo.org/public/ english/employment/finance/ download/remitrept.pdf. 
IMF

2001 Balance of Payments Yearbook 2001, IMF, New York.

INSTRAW and IOM

2000 Temporary Labour Migration of Women. Case Studies of Bangladesh and Sri Lanka, INSTRAW/IOM, Santo Domingo, Dominican Republic.

International Development Group (IDG) of the British-Bangladeshi Professionals Association (BBPA)

2003 What Can DFID Do Better for Bangladesh?, A report by the International Development Group (IDG) of the British-Bangladeshi Professionals Association (BBPA), London.

IOM

2002 National Community Funds Program for Guatemala: Joint Investment System between Local Villager and Migrants, (Working Document), IOM, Guatemala.

2003 Labour Migration in Asia. Trends, Challenges and Policy Responses in Countries of Origin, IOM, Geneva, http://www.iom.int//DOCUMENTS/PUBLICATION/EN/ LabourMigAsia.pdf.

2004 IOM New's, September 2004, In depth focus on remittances, IOM, Geneva, http:/ /www.iom.int//DOCUMENTS/PUBLICATION/EN/IOMNews_Sep04.pdf.

Iredale, R., and F. Guo

2001 "The transforming role of skilled and business returnees: Taiwan, China and Bangladesh", paper presented at $24^{\text {th }}$ IUSSP General Conference, Salvador, Brazil, 18-24 August, http://www.iussp.org/Brazil2001/s30/S39_04_Iredale.pdf.

Islam, $\mathrm{T}$.

2002 "Government may lift of ban on domestic workers. Bangladesh considers exporting women, for foreign exchange" in South Asia Tribune, No. 11, 30 September6 October, http://www.satribune.com/archives/sep30_oct06_02/opinion_ bangladesh women.htm.

Jolly, S.

2003 "Gender and migration in Asia: overview and annotated bibliography", paper presented at the Conference on Migration, Development and Pro-poor Policy Choices in Asia, Dhaka, 22-24 June.

Jureidini, R.

2001 Migrant Workers and Xenophobia in the Middle East, prepared for the UNRISD Conference on Racism and Public Policy, Durban, SA, UNRISD, Geneva.

Kuddus, U.M.

2003 Channeling Diaspora Remittance into the Securities Market of Bangladesh, internship report for IOM, Institute of Business Administration, University of Dhaka, Dhaka.

Kuhn, R.

2001 Never Far from Home: Parental Assests and Migrant Transfers in Matlab, Bangladesh, Labor and Population programme, RAND, Santa Monica, http:// www.rand.org/labor/DRU/DRU2578.pdf.

Kuhn, R.S.

2002 "The logic of letting go: family and individual migration from rural Bangladesh", submitted for Demography, http://delta.grot.org/rc/rp001.pdf. 
Kuhn, R.S., and J.A. Menken

2002 "Migrant social capital and education in migrant-sending areas of Bangladesh: complements or substitutes?", manuscript, http://delta.grot.org/rc/rp008.pdf.

Mahmood, R.A.

1991 "Bangladeshi returned migrants from the Middle East: process, achievement, and adjustment" in G. Gunatilleke (Ed.), Migration to the Arab World. Experience of Returning Migrants, United Nations University Press, Tokyo, pp. 238-289.

1992 "Bangladesh" in G. Gunatilleke (Ed.), The Impact of Labour Migration on Households. A Comparative Study in Seven Asian Countries, United Nations University Press, Tokyo, pp. 24-60.

MEWOE (Ministry of Expatriates' Welfare and Overseas Employment)

2002 Annual Report-2002, MEWOE, Dhaka.

Morshed, S.M.

s.d. Pre-departure, Reintegration and Policy Advocacy in the Migration Process, http:/ /aidsouthasia.undp.org.in/publicatn/6TH\%20ICCAP/pdfs/bangla.pdf.

Murshid, K.A.S., K. Iqbal, and M. Ahmed

2002 A Study on Remittance Inflows and Utilization, IOM, Regional Office for South Asia, Dhaka.

Orozco, M.

2000 "Latino Hometown Associations as agents of development in Latin America", Inter-American Dialogue, http://www.thedialogue.org/publications/country

Passas, N. studies/remittances/ OrozcoHTAs.pdf.

1999 Informal Value Transfer Systems and Criminal Organizations: A Study into So-called Underground Banking Networks, http://www.minjust.nl:8080/b_organ/ wodc/ publications/ivts.pdf.

Penent, A. (Ed.)

2003 La valorisation économique de l'épargne des migrants. Epargner ici, investir làbas, un état des lieux, FORIM, FINANSOL et CFSI, Paris.

Puri, S., and T. Ritzema

1999 Migrant Worker-Remittances, Micro-Finance and the Informal Economy: Prospects and Issues, ILO Social Forum Unit, Working Paper No. 21, http://www.ilo.org/ Rahim, N. public/english/employment/finance/ papers/wpap21.htm.

2001 A Tarnished Golden Deer: The Regime for Bangladesh Migrant Worker; Programme for Research on Poverty Alleviation Research Report Series, No. 83, Grameen Trust, Dhaka.

RMMRU

2002 Recruitment and Placement of Bangladeshi Migrant Workers. An Evaluation of the Process, IOM, Dhaka.

Russell, S.S.

1986 "Remittances from international migration: a review in perspective" in World Development, 14(6): 677-696. 
Shah, V., B. Brar, and S.Y. Rana

2002 Layers of Silence: Links between Women's Vulnerability, Trafficking and HIVI AIDS in Bangladesh, India and Nepal, draft paper prepared for the UNRISD project HIV/AIDS and Development, UNRISD, Geneva.

SHISUK

2002 Final Report. Pilot Intervention with Migrant Workers and his Families, a project organized by SHISUK and supported by IOM, ILO, UNAIDS, Dhaka.

Siddiqui, T.

2002a "Migration challenges of Bangladesh: options and policy recommendations", paper presented at a conference on Orderly and Humane Migration: an Emerging Development Paradigm, organized by IOM and IBS of Rajshahi University, held

Siddiqui, T. (Ed.) in Rajshahi on 6 August 2002.

2002b Beyond the Maze: Streamlining Labour Recruitment Process in Bangladesh, RMMRU, Dhaka.

Siddiqui, T.

2003 "Migration as a livelihood strategy of the poor: the Bangladesh case", paper presented at the Conference on Migration, Development and Pro-poor Policy Choices in Asia, Dhaka, 22-24 June, http://www.livelihoods.org/hot_topics/docs/ Dhaka_CP_5.pdf.

2004a "Migrants' remittances and micro finance in Bangladesh" presentation made at the associated session Linking International Migrant Remittance to Microenterprise Initiative in Bangladesh: Possibilities and Potentials, at the Asia Pacific Region Microcredit Summit Meeting of Councils, 16-19February 2004, PKSF, Microcredit Summit Campaign, Dhaka.

2004b Institutionalizing Diaspora Linkage. The Emigrant Bangladeshis in UK and USA, MEWOE and IOM, Dhaka, http://www.iom.int/DOCUMENTS/PUBLICATION/ EN/bangladesh_diaspora.pdf.

Siddiqui, T., and C.R. Abrar

2001 Migrant Worker Remittances and Micro-Finance in Bangladesh, ILO, Dhaka/ Geneva.

2002 Contribution of Returnees: An Analytical Survey of Post Return Experience, IOM, Dhaka.

Siddiqui, T., S. Malik, and C.R. Abrar

1999 International Labour Migration and the Role of the Trade Unions, ILO, Dhaka.

Skeldon, R.

2003 "Migration and migration policy in Asia: a synthesis of selected cases", paper presented at the Conference on Migration, Development and Pro-poor Policy Choices in Asia, Dhaka, 22-24 June, http://www.livelihoods.org/hot_topics/docs/ Dhaka_CP_1.pdf.

Tahmina, Q.A.

2003a "International Migrant's Day/Society - Bangladesh: Wives at home worry about husband's fidelity", Inter Press Service, 18 December 2003, http://www.aegis.com/ news/ips/2003/IP031225.html. 
2003 b “International Migrant's Day/Society - Bangladesh: Women learn tough lessons from work in Malaysia" in Inter Press Service, 18 December 2003, http:// www.aegis.com/news/ips/2003/ IP031226.html.

Taylor, J.E.

1999 "The new economics of labour migration and the role of remittances in the migration process", International Migration, 37(1): 63-88.

The Bangladesh Observer

1999 "PM's intervention sought. Misuse of money of Wage Earners' Welfare Fund alleged", 7 August 1999.

UN (United Nations) General Assembly

1990 International Convention on the Protection of the Rights of All Migrant Workers and Members of Their Families, A/RES/45/158, http://www.migrantsrights.org/

UN Int_Conv_Prot_Rights_MigWorkers_Fam_1999_En.htm\#part1.

2002 International Migration Report 2002, UN, New York.

Van Doorn, J.

s.d. Migration, Remittances and Small Enterprise Development, ILO, http:// www.ilo.org/public/english/ employment/finance/download/remit2.pdf.

2002 "Migration, remittances and development", Labour Education, 4(129): 48-53, http:/ Waddington, C. /www.ilo.org/ public/english/dialogue/actrav/publ/129/8.pdf.

2003 "International migration policies in Asia. A synthesis of ILO and other literature on policies seeking to manage the recruitment and protection of migrants, and facilitate remittances and their investment", paper presented at the Conference on Migration, Development and Pro-poor Policy Choices in Asia, Dhaka, 22-24 June,

Wickramasekera, $\mathrm{P}$. http://www.livelihoods.org/hot_topics/docs/Dhaka_CP_10.pdf.

2002 Asian Labour Migration: Issues and Challenges in an Era of Globalization, International Migration paper no. 57, IOM, ILO, Geneva.

Wilson, J.F.

2002 Hawala and Other Informal Payments Systems: an Economic Perspective, Seminar on Monetary and Financial Law, 16 May 2002, http://www.imf.org/external/np/ leg/sem/2002/cdmfl/eng/wilson.pdf.

Wilson, J., and R. Ballard

2003 Informal Funds Transfer Systems: An Analysis of Hawala, EDD and SLSO-ASREP

Lunchtime Seminar, 10 January 2003, Department for International Development, World Bank

London, http://www.livelihoods.org/hot_topics/docs/Migr_100103.doc.

2004 Global Development Finance. Harnessing Cyclical Gains for Development, World Bank, Washington, http://siteresources.worldbank.org/GDFINT2004/Home/ 20177154/GDF_2004\%20pdf.pdf. 


\section{World Migration 2005 Available in May 2005}

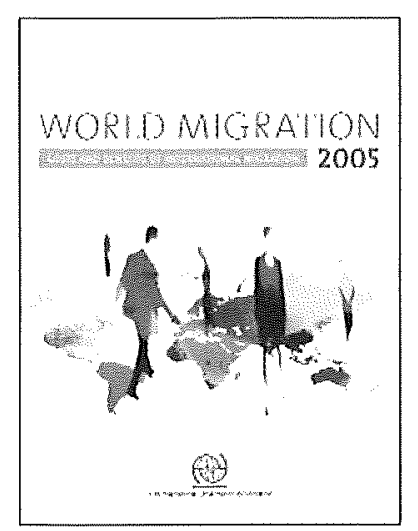

Where are people migrating today and why? What are the implications for the world's developing and industrialized economies? And what are the key issues facing policy makers in migrant origin, destination, and transit countries?

World Migration 2005, IOM's flagship biennial publication, will focus on the theme of Economies of Migration: Costs and Benefits of International Migration.

Featuring contributions from the world's leading experts, it will present the latest trends in international migration, as well as regional overviews of developments in Africa, the Americas, Asia and Europe.

World Migration 2005 will analyse the contribution of global-

ization, trade liberalization, economic integration and the widening gap between rich and poor nations to migration flows.

It will look at the impact of the world's 175 million migrants and their potential contribution to socio-economic development and cultural enrichment both at home and abroad.

And it will identify the multi-dimensional migration management policies needed by governments to create the optimal return to both migrants and society, while minimizing the abuses associated with irregular migration.

\section{5; ISBN 92-9068-209-4; Softcover}

\section{IOM publications are available from:}

International Organization for Migration, Research and Publications Unit 17 route des Morillons, $\mathrm{CH}-1211$ Geneva 19 Switzerland

Tel: +41.22.717 91 11, Fax: +41.22.798 6150, E-mail: publications@iom.int

Payment must accompany orders and can be made by international bank draft or money order in US dollars payable to International Organization for Migration, Geneva. Please add $10 \%$ of sales price for handling and postage.

IOM publications are also sold through the sales offices of the United Nations E-mail: unpubli@unog.ch (Geneva) or publications@un.org (New York)

The list of IOM publications may be found on the IOM website: 


\section{The World in Motion: \\ Short Essays on Migration and Gender}

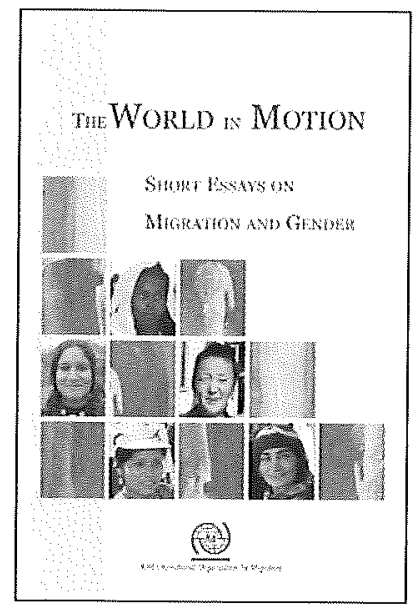

This book will look at migration and select moments in time, past and present, through the experience of women. The feminization of migration, like the feminization of poverty, is a catchphrase. People use it in an effort to be "gender sensitive"; yet, the term itself has still to be defined and mainstreamed much like waiting for a fuzzy Polaroid photo to develop into a precise image. You wave it around and slowly shapes begin to take on form and a clear picture appears. This is what we hope to achieve with this book. We hope to raise the visibility of the existing data and casework, to include what has been examined and interpreted by a few, and to present a snapshot of what the catchphrase "feminization of migration" means today and to what issues it may refer to in the future. The book will map out a set of preliminary but common understandings on issues of importance to migrant women and their advocates, and further clarify the experience of women across several key themes: labour migration, migrant remittances, trafficking, immigration and identification - all of which are key areas of migration studies. It will also put forward issues such as rape and female circumcision, key issues of importance to the integration of both forced migrants and of women who migrate into new cultural norms. Thus, for the student or practitioner of migration these issues are relevant to understanding the experience and needs of thousands of women who find themselves, willing or unwilling, migrants.

2004; ISBN 92-9068-228-8; 115 pages; Softcover; US $\$ 20.00$

\section{IOM publications are available from:}

International Organization for Migration, Research and Publications Unit 17 route des Morillons, $\mathrm{CH}-1211$ Geneva 19 Switzerland

Tel: +41.22.71791 11, Fax: +41.22.798 61 50, E-mail: publications@iom.int

Payment must accompany orders and can be made by international bank draft or money order in US dollars payable to International Organization for Migration, Geneva. Please add $10 \%$ of sales price for handling and postage.

IOM publications are also sold through the sales offices of the United Nations E-mail: unpubli@unog.ch (Geneva) or publications@un.org (New York)

The list of IOM publications may be found on the IOM website:

http://www.iom.int 


\section{IOM MIGRATION RESEARCH SERIES}

1. Myths and Realities of Chinese Irregular Migration Ronald Skeldon, December 2000

2. Combating Trafficking in South-East Asia: A Review of Policy and Programme Responses Annuska Derks, December 2000

3. The Role of Regional Consultative Processes in Managing International Migration

Amanda Klekowski von Koppenfels, May 2001

4. The Return and Reintegration of Rejected Asylum Seekers and Irregular Migrants: An Analysis of Government Assisted Return Programmes in Selected European Countries Khalid Koser, May 2001

5. Harnessing the Potential of Migration and Return to Promote Development Savina Ammassari and Richard Black, August 2001

6. Recent Trends in Chinese Migration to Europe: Fujianese Migration in Perspective Frank N. Pieke, March 2002

7. Trafficking for Sexual Exploitation: The Case of the Russian Federation Donna M. Hughes, June 2002

8. The Migration-Development Nexus: Evidence and Policy Options Ninna Nyberg-Sorensen, Nicholas Van Hear and Poul Engberg-Pedersen, July 2002

9. A Review of Data on Trafficking in the Republic of Korea June J.H. Lee, August 2002
10. Moroccan Migration Dynamics: Prospects for the Future Rob van der Erf and Liesbeth Heering, August 2002

11. Journeys of Jeopardy: A Review of Research on Trafficking in Women and Children in Europe Elizabeth Kelly, November 2002

12. Irregular Migration in Turkey Ahmet Içduygu, February 2003

13. Bordering on Control: Combating Irregular Migration in North America and Europe Philip Martin, April 2003

14. Migration and Development: A Perspective from Asia Graeme Hugo, November 2003

15. Is Trafficking in Human Beings Demand Driven? A Multi-Country Pilot Study Bridget Anderson and Julia O'Connell Davidson, December 2003

16. Migration from Latin America to Europe: Trends and Policy Challenges Adela Pellegrino, May 2004

17. The Development Potential of Zimbabweans in the Diaspora: A Survey of Zimbabweans Living in the UK and South Africa Alice Bloch, January 2005

18. Dynamics of Remittance Utilization in Bangladesh Tom de Bruyn, January 2005 